
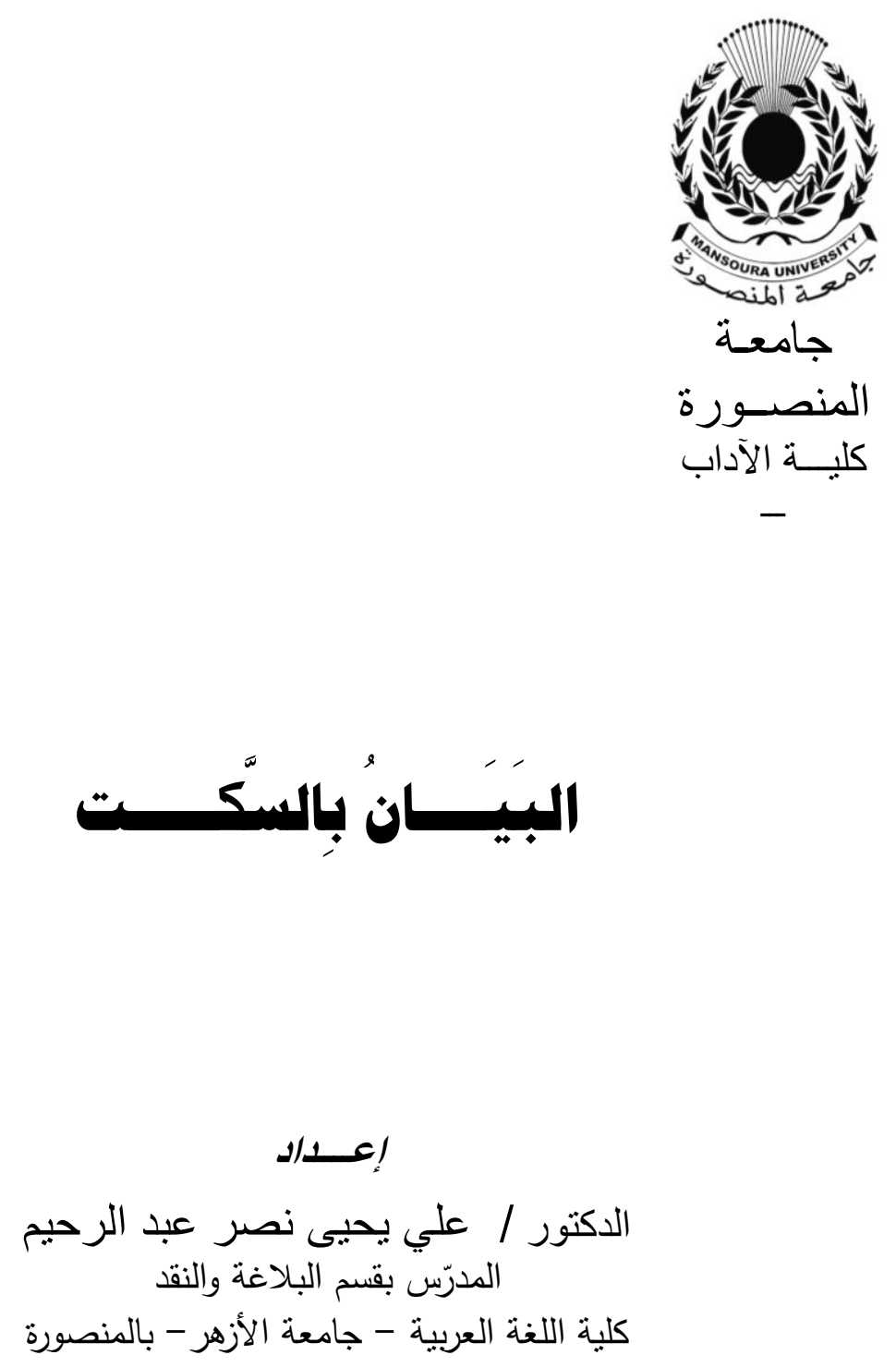

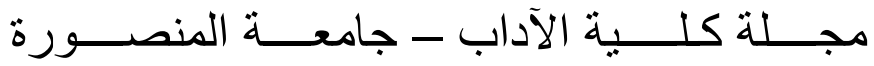

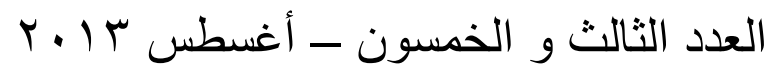




\section{البَيَانْ بِالسَّكتت}

د.علي يحيى نصر عبد الرحيم

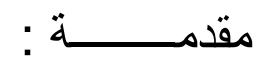

الحمد لله الرحيم الرحمن، خلق الإنسان، علّمه البيان، والصّّلاة والستّام على ألى

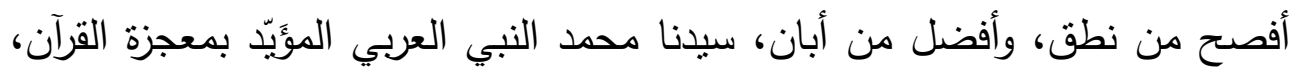
وعلى آله وصحبه والتابعين لهم بإحسان، أمّا بعد..

فإنّ البيانَ العربي في سبيل تحقيق أغراضه الإبداعية والإمتاعية والإقناعية،

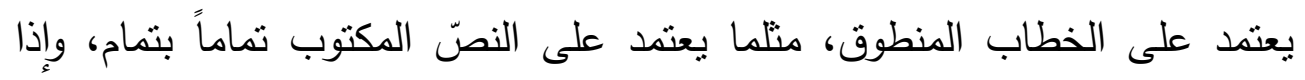

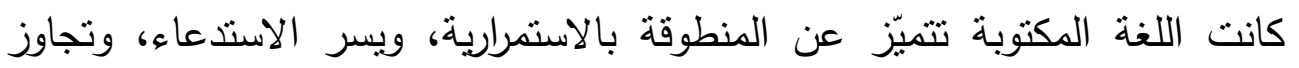

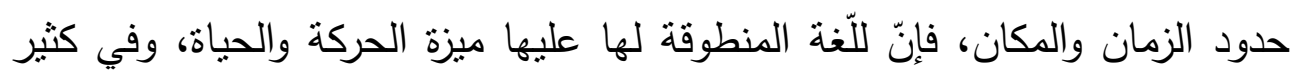

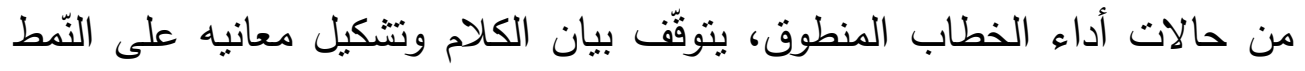

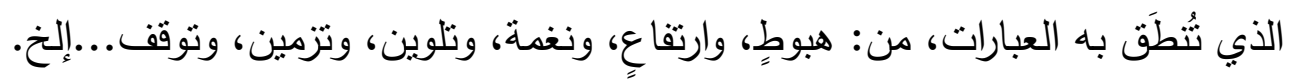
ومن بين الأنماط الأدائية المنتوعة، ييرز الأداء بالستكت كعنصر حيوي وفاعل

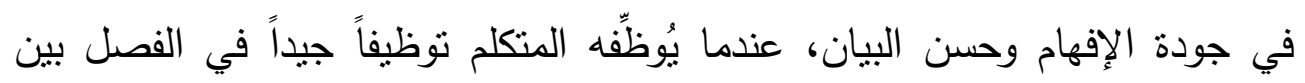

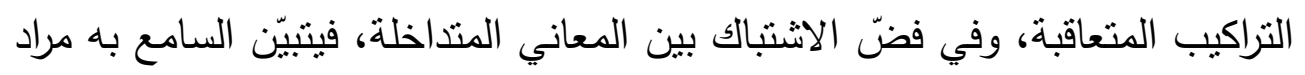

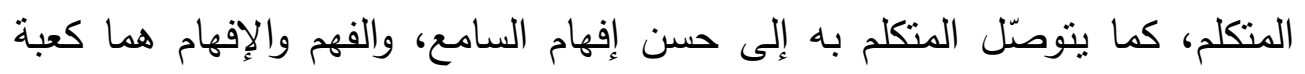

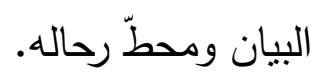

وإذا كان البيان العربي كخطاب منطوق، لم يحظً في الدراسات التراثية بالنصيب

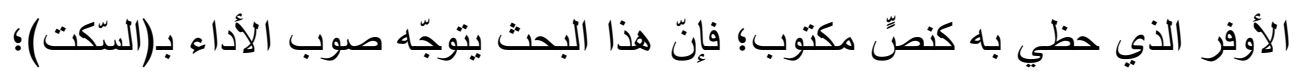

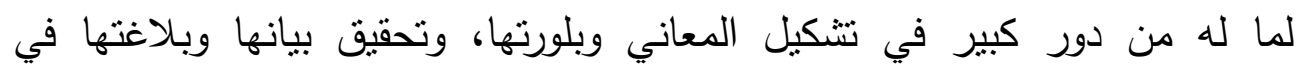

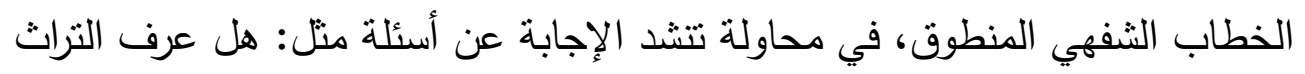
العربي هذا النمط من الأداء؟ وهل ثمة علاقة بين الأداء بالستّت والبيان؟ وما دور الإنة 
السيّكت في تحقيق الأثز البلاغي، وفي نتكيل المعاني النحوية؟ وما مدى فاعليته في الخطاب المنطوق في القراءة الجهرية للنصوص العربية، وفي فن الإلقاء؟ وكيف يكون الأداء به؟ وماذا عن السّكت في الأداء القرآني؟

وقد سلك البحث سبيل المنهج الوصفي التحليلي، بالاطّّلاع على المصادر والمراجع العلمية في هذا الصدد اطلاعاً دقيقاً، مع مقارنة الأفكار والآراء في أسلوبٍ هو إلى الإيجاز أميل؛ وفي حبكة بحثية تعتمد كثيراً على الإشارات والإحالات.

وقد جاءت الدراسة في ثناثة مباحث، يسبقها تمهيد، وتلحقها خاتمة، على النحو

التمهيذ: فيه نبذة عن مفهوم مصطلحي العنوان: (البيان) و (السكت).

$$
\text { المبحث الأول: السّكت في التراث العربي. }
$$

المبحث الثاني: السّكت والبيان.

المبحث الثالث: السيّكت في أداء القرآن الكريم.

الخاتمة، متضدنة النتائج والتوصيات المقترحة.

ومن حسن طالع هذا البحث أنني طرحت فكرته بعد نضجها في بلد الله الأمين (مكة المكرمة) خلال فعاليات (المؤتمر الدولي الأول لعلوم العربية في التعليم الجامعي بين التحصيل العلمي والتكوين المهاري)، الذي انعقد في رحاب كلية اللغة

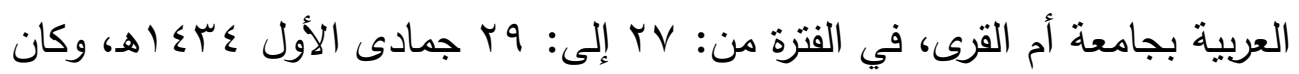
من بين المشاركين في نقاش الفكرة وإثرائها أساتذة أعلام لهم فضلهم ومكانتهم في خدمة البحث اللغوي والبلاغي، منهم الأستاذ الدكتور سليمان العايد، وأستاذنا الدكتور محمد شادي، فكان لنقاشهما الذي أعتز به دور كبير في توجيه البحث نحو صيغته الأخيرة التي انتهى إليها. 
د. على يحي نصر عبدالرحيم

ك

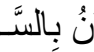

هذا، وما كان من نوفيق في هذا العمل فمن اله وحده لا شريك له، هو الذي

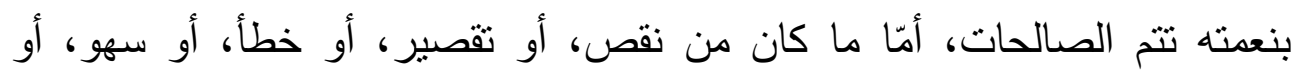

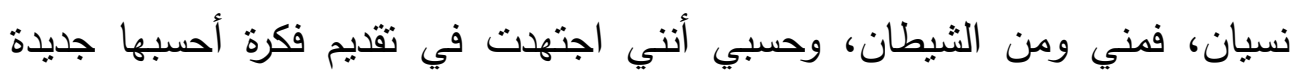

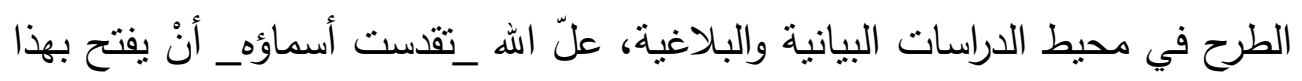

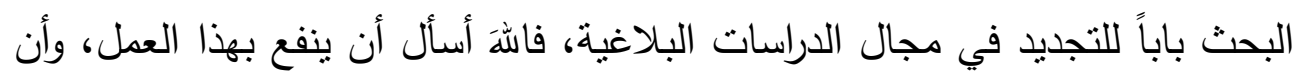

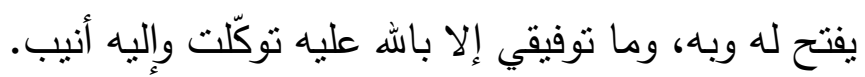

الباحث

د. علي يحيى عبد الرحيم 


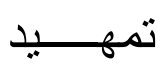

( $)$

البيان: يدور معناه في اللغة حول الإفصاح، والإظهار، وإيضاح الدلالة بلفظ

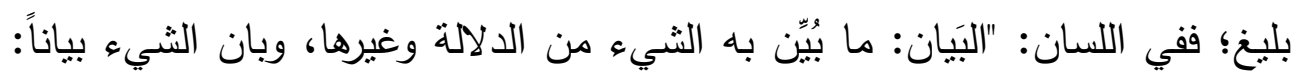

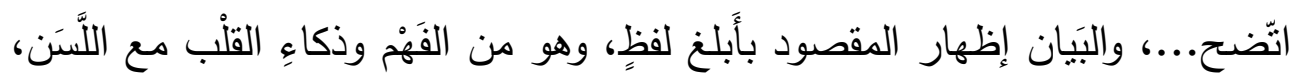
وأَصَلُهُ الكَثَنْفُ والظُهورُ "( (1).

وقد كان الفكر العربي المصنِّف حتى القرن السادس الهجري مستوعباً لمحيط أكثر

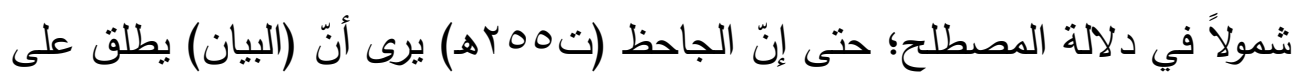

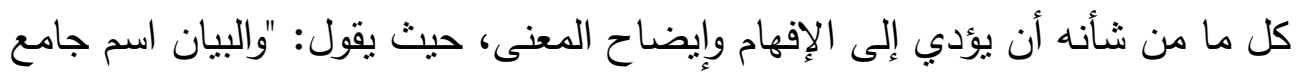

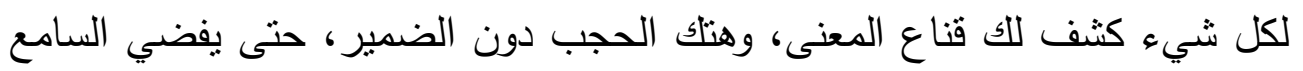

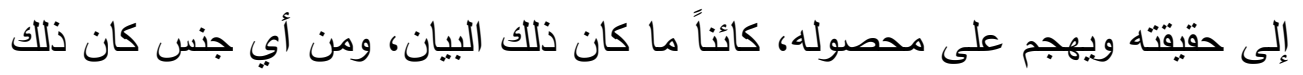

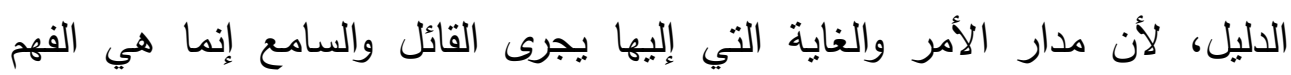

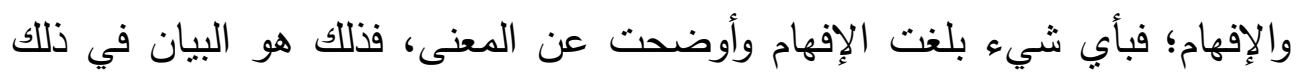

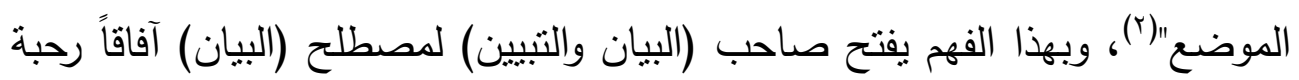
تسنوعب العديد من وسائل الإيضاح والإفهام.

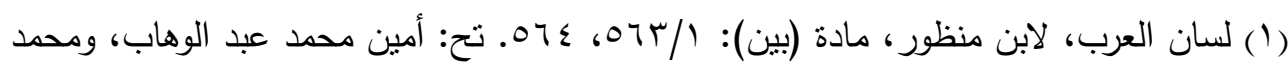

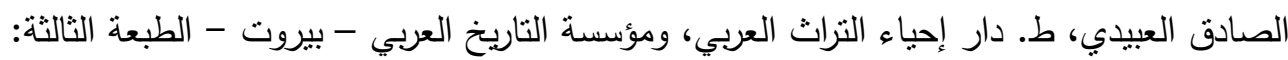
. 1999 / 199 (ז) البيان والتبيين، للجاحظ: /1/1/، تحقيق: عبد السلام محدد هارون، نثر مكتبة الخانجي -

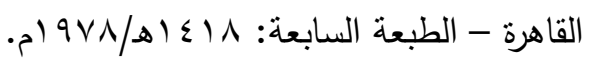


وقد عدّد الجاحظ وسائل البيان وأصناف الدلالات، وجعلها في خمسة أثشاء، حيث قال: "وجميع أصناف الدلالات على المعاني من لفظٍ وغير لفظ، خمسة أثنياء

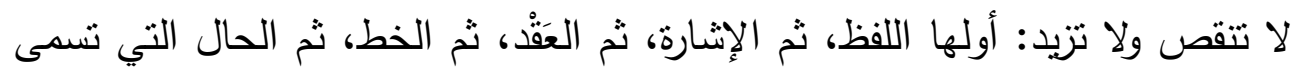

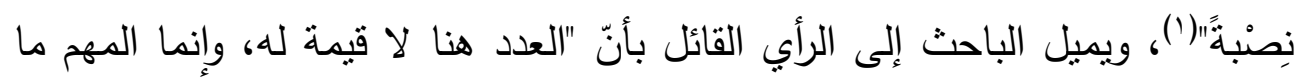
تعنيه تلاك الوسائل من أنها لا تقل أهمية بحال من الأحوال عن الألفاظ في تكوين

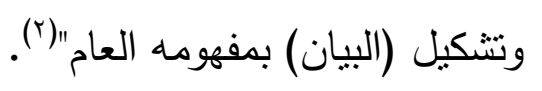

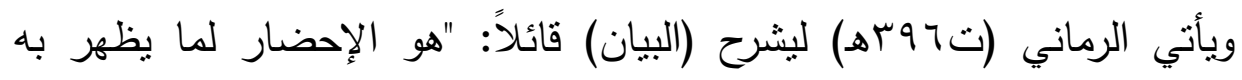

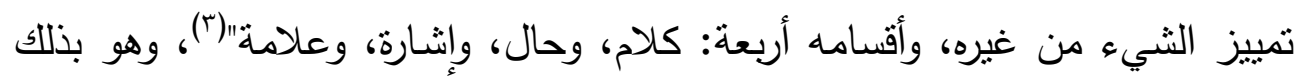

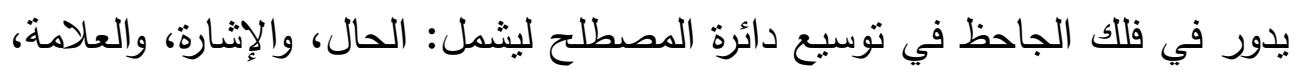
بالإضافة إلى الكلام.

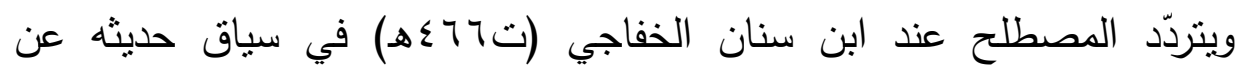
الفصاحة، وعن الأسباب التي لأجلها يغمض الكلام على السامع، ولا تراه يعني

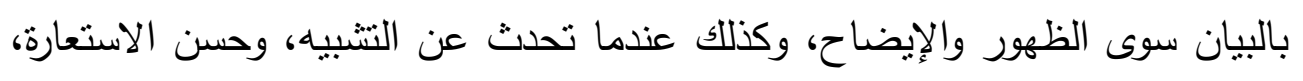

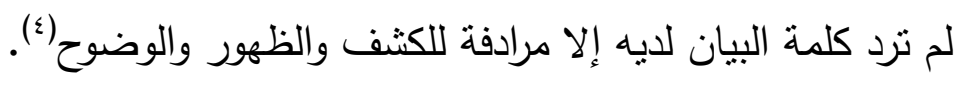

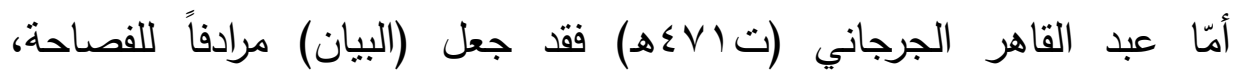
والبلاغة، والبراعة، وكل هذه الدصطلحات تعني عنده: "وصف الكلام بحُسن الدلالة،

(1) انظر السابق: نفسه.

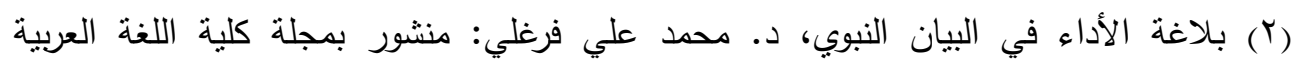

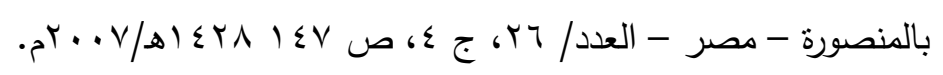

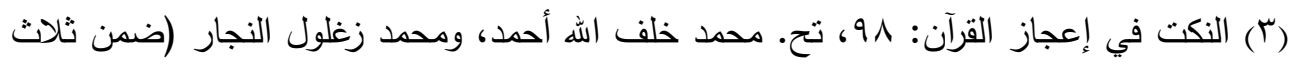

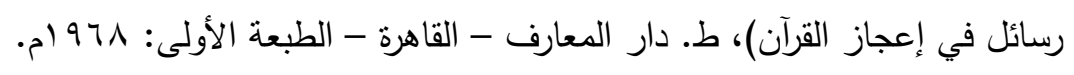

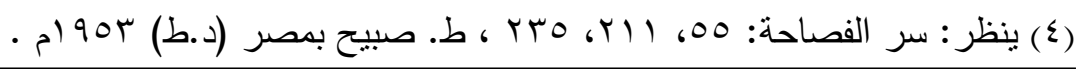


وتمامها في ما له كانت دلالة، ثم تبرجها في صورة هي أبهى وأزين، وآنق

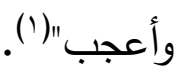

وظل المصطلح هكذا واسعاً فضفاضاً حتى كان تقيم علوم البلاغة على يد السكَّاكي (ت وبآهـ)، الذي جعل (علم البيان) قسيماً لعلم المعاني في تصنيف البلاغة، معرّفاً إياه بقوله: "هو معرفة إيراد المعنى الواحد في طرق مختلفة بالزيادة في وضوح الدلالة عليه، وبالنقصان؛ ليحترز بالوقوف على ذلك عن الخطأ في مطابقة الكلام لتمام المراد منه"(؟)، وجعل مرجعه اعتبار جهتين: جهة الانتقال من ملزوم إلى دئ

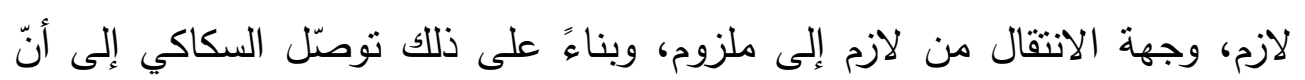
انصباب علم البيان إلى التعرض للمجاز والكناية، إضافة إلى (التشبيه) الذي بدأ به؛ لأنّ الاستعارة من فروع التشبيه(r).

من خلال ما سبق يتبيّن للك أنّ الفكر العربي المصنّف قبل السكّاكي كان ينظر إلى مصطلح (البيان) نظرة أكثر شمولية واتساعاً، فالبيان لدى الجاحظ والرماني يستوعب العديد من مظاهر الدلالة، ويدور على محور إفهام المخاطَب وإيضاح المعنى له، سواء باللفظ أو بغير اللفظ، والبيان لدى عبد القاهر الجرجاني يرادف الفصاحة، والبلاغة، والبراعة، ووصف الكلام بحسن الدلالة وتمامها، وإذا كان الفكر

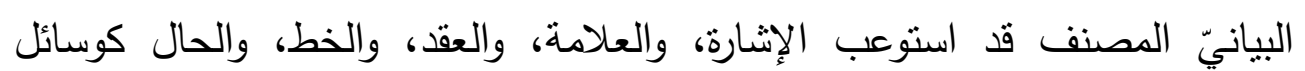

(1) ينظر : دلائل الإعجاز : rع؛، تح. محمود محمد شاكر، ط. المدنى بالقاهرة وجدة - الطبعة

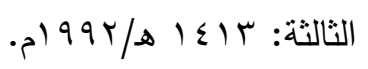

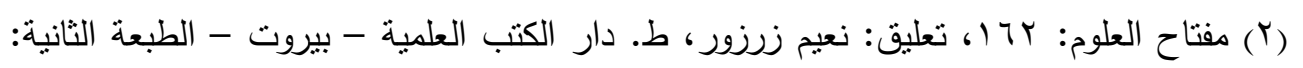
. $9 \lambda \mathrm{P} / \mathrm{s}) \leq \cdot \mathrm{V}$

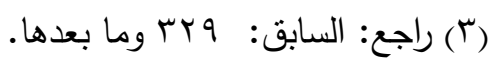
$7 . \varepsilon$ 
لتحقيق البيان غير اللفظ، فقد كان من باب أولى أن بستوعب الأداء(') بأنماطه المتعددة المصاحبة للكلام المنطوق من: الإيقاع، والوقف، والسكت، والهيوط،

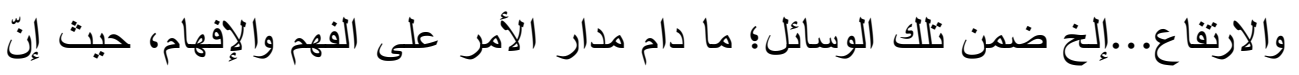
الأداء في البيان المنطوق له دور كبير في بلورة المعاني وتتكيلها، يقول أستاذنا الدكتور جبل: "الأداء السليم للغة يحفظ لها رونقها في الأسماع، ووقعها الساحر في لئي

(1) ارتبط مصطلح (الأداء) في التراث العربي بالممارسة الصوتية المجوّدة للقرآن الكريم؛ ففي

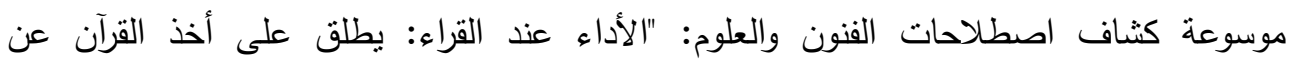

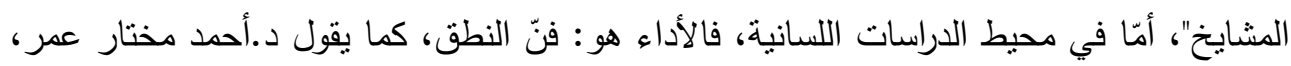
أو فنّ إلقاء الكلام؛ حيث يقول د. كمال بشر : "الكلام بمعنى عملية أداء الرسالة اللغوية نطقاً، أو فئاء كيفية إلقائها، فن من الفنون التي يصعب على كثير من الناس إدراك أهميتها، وتذوق قيمتها، وأسرار

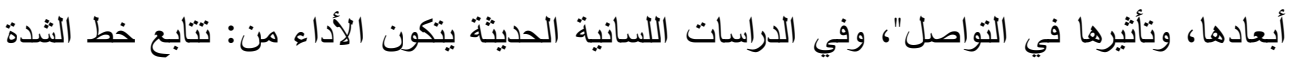
(Intensity) (Pitch)، وهو الذي يسمى (Melody)، ومن تتابع خط الكم الزمني للأصوات (Duration)، أو

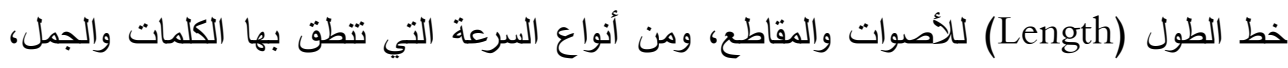
وهو الذي يسمى التزمين (Tempo)، ومن تتابع خط اللون (Color) للأصوات، ومن نظام

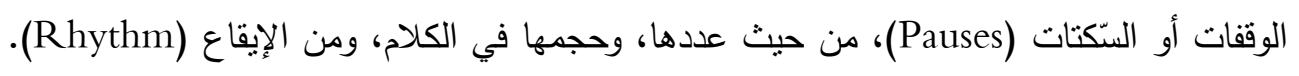

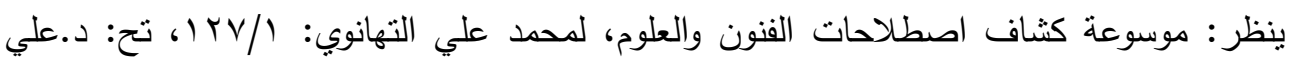

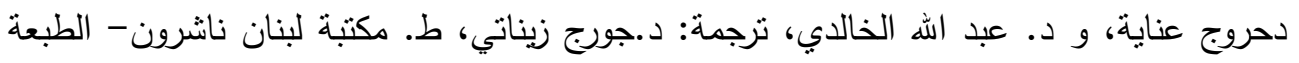

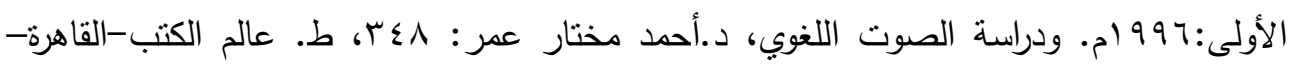

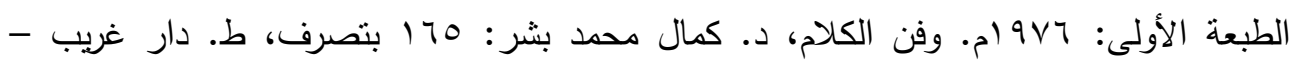

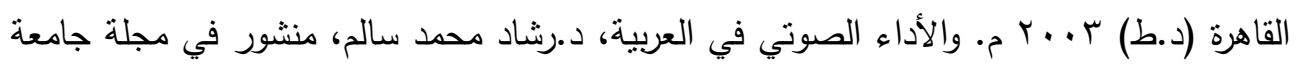

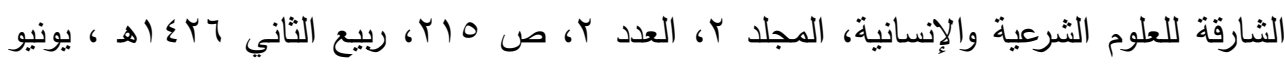

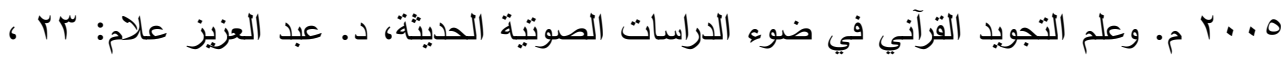

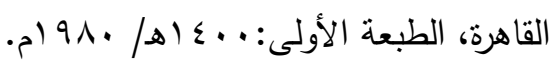


الطباع، ويفتح لها القلوب فتعي ما تسمع، ثم تتأمله في أناة وارتياح"((')، ويأمل الباحث

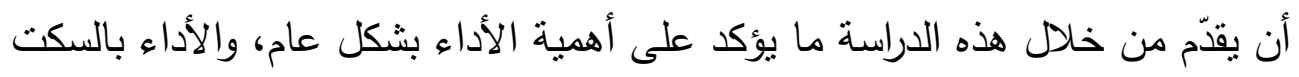

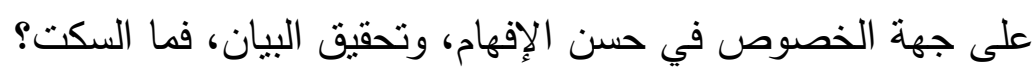

(r)

الستّت: في معجم (مقاييس اللغة): "السين والكاف والتاء، يدلُ على خِلاف

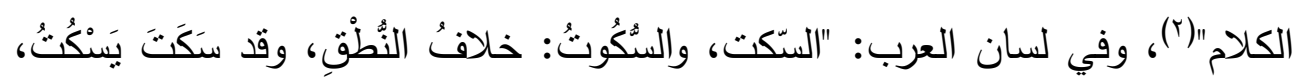

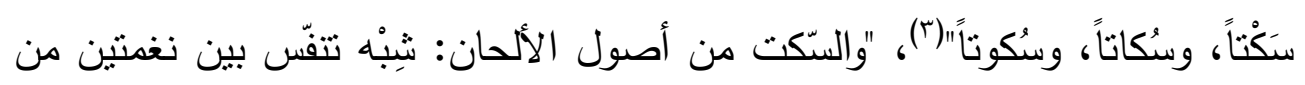

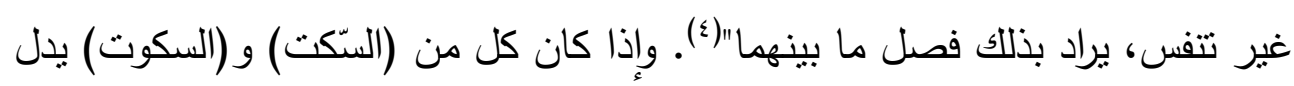

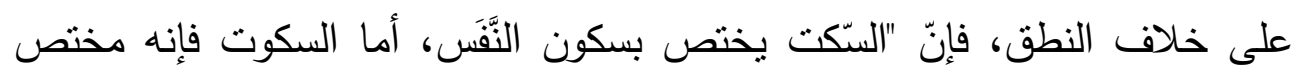

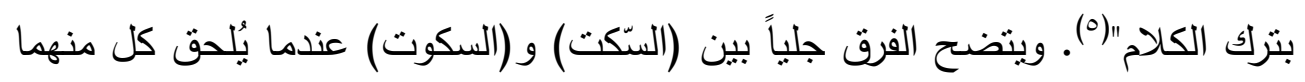

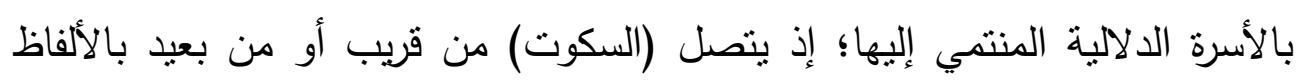

(1) أصوات اللغة العربية دراسة نظرية وتطبيقية، د. محمد حسن جبل: 1 ، ط. مطبعة أوفست-

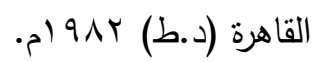

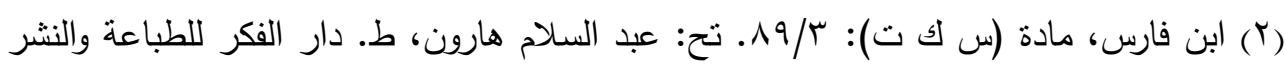

$$
\text { والتوزيع- القاهرة- (د.ت). }
$$

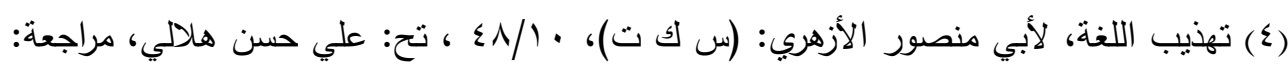

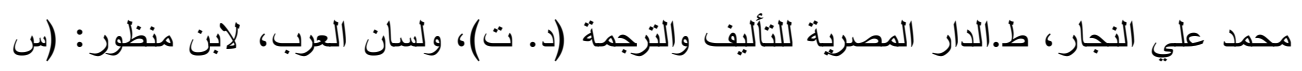

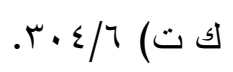
(0) المفردات في غريب القرآن، للراغب الأصفهاني: بـآ؟، تح. محمد كيلاني، ط. دار المعرفة-

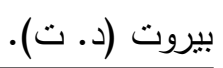


الدالّة على ترك الكلام، كالصّتت، والإنصات، والإطراق، والوجوم(')، أما (الستّت)

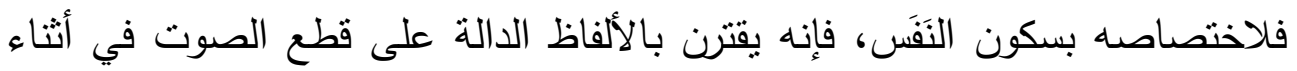
الكلام، كالوقف، والقطع، ومن ثم ارتبط مصطلح (السّكت) في التراث العربي بعلم التجويد، على أنه نمط مخصوص من أنماط الأداء القرآني.

والستّت في اصطلاح علماء التجويد: "عبارة عن قطع الصوت زمناً هو دون

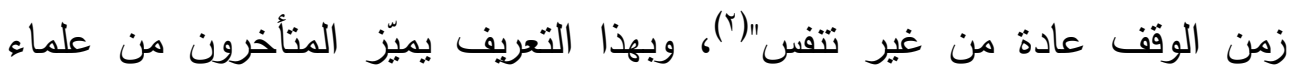
التجويد(r) مصطلح (الستّت) عن كل من قرينيه: (الوقف)، و (القطع) بالكيفية التي مني

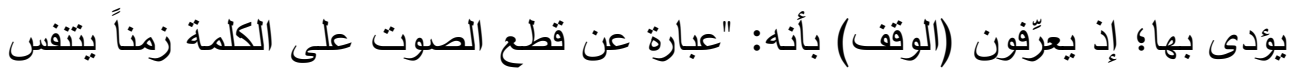

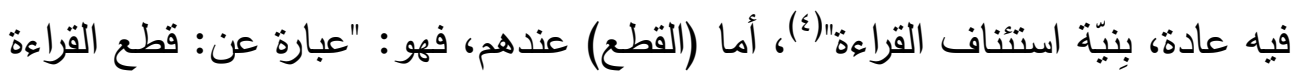

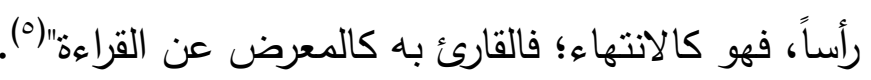
أمّا الدحدثون من اللغويين، فمنهم من التزم بمفهوم (الستكت) عند الأقدمين، في

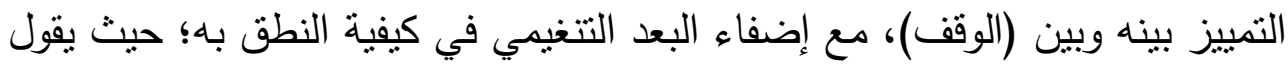

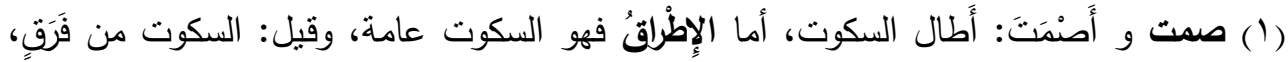

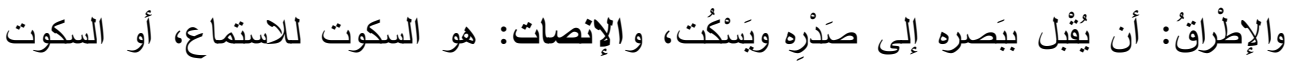

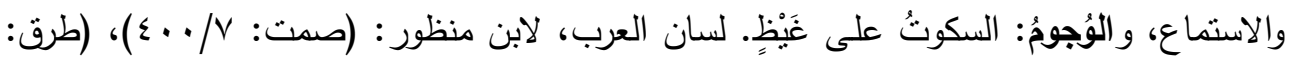

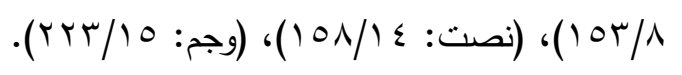

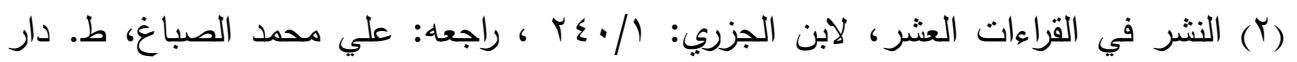

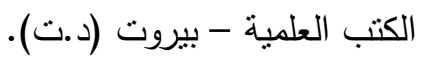

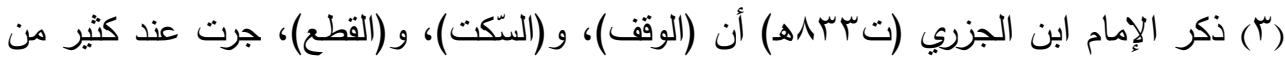

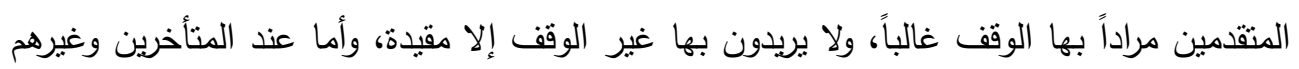

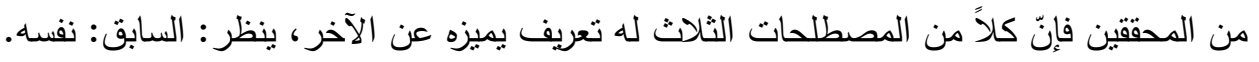

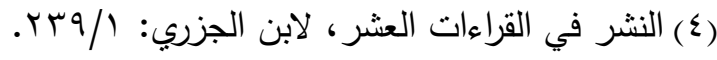


د. كمال بشر : "السّكتة في اصطلاحنا أخفّ من الوقفة، وأدنى منها زمناً، وهي في حقيقة الأمر لا تعني إلا مجرد تغيير مسيرة النطق بتغيير نغماته، إثعاراً بأن ما

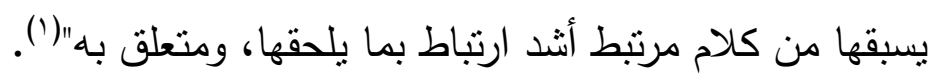
فمفهوم (السكتة) إذن لدى كمال بشر، يتّفق كثيراً مع مفهومها لدى المتأخرين من علماء التجويد، الذين ميّزوا (السكت) عن (الوقف) بالخفّة في الأداء، والقلة في الزمن، ولا يزيد تعريفه على ذلك إلا بربط (السكت) بالتنغيم(r) عند النطق به؛ باء

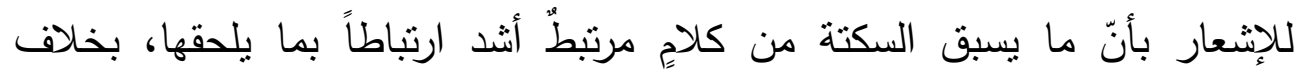

(1) علم الأصوات، د. كمال بشر: OVV، ط. دار غريب - القاهرة - الطبعة الأولى: . (r) (التنغيم) كما يقول د. محمود السعران: "هو الهصطلح الصوتي الدال على الارتفاع (الصعود)،

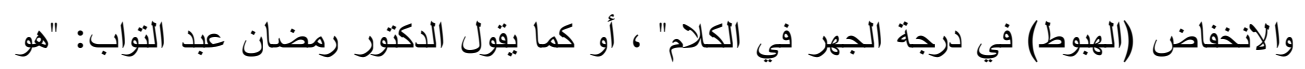

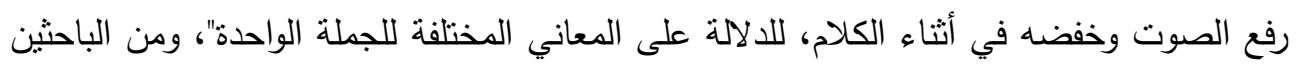

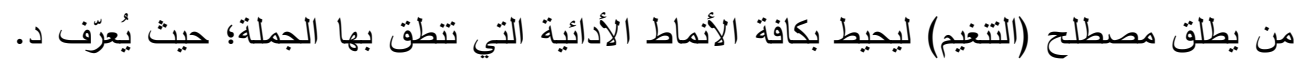

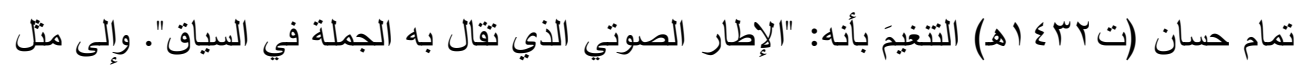

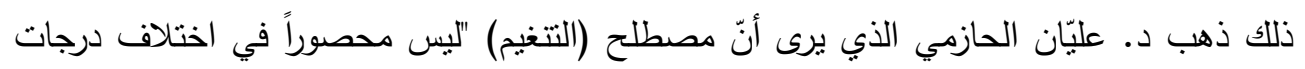

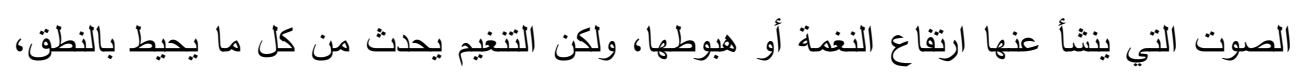

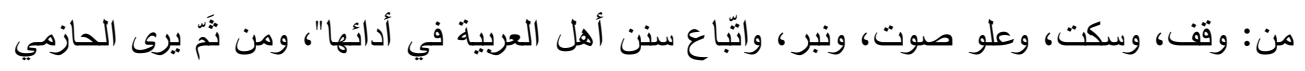

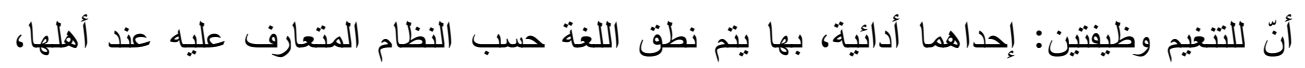
والأخرى دلالية، تتضح بها الدلالات المختلفة ومقاصد الكلام. ينظر: علم اللغة مقدمة للقارئ

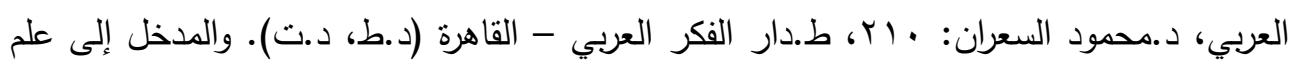

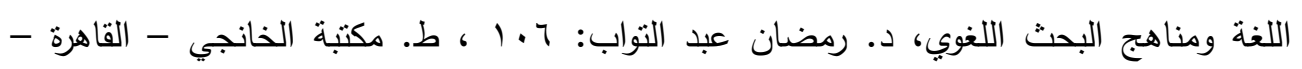

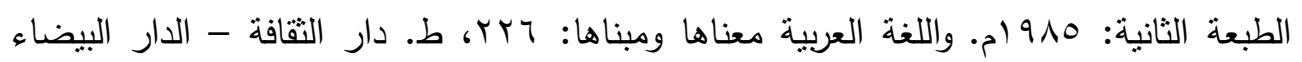

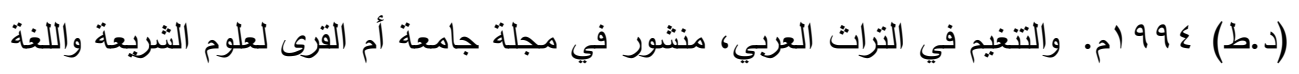

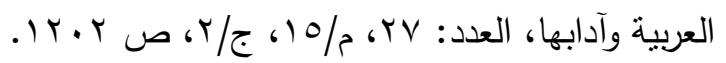


(الوقف) الذي يُشعر الأداء به بانفصام لاحقِ الكلام عن سابقه، وهذا ملمح جيد، يأخذ في الاعتبار الدور الحيوي للسكت في تشكيل معاني الجمل والعبارات المنطوقة.

وإلى نحو قريب من ذلك يذهب د. مصطفى النحاس، الذي يعرّف السّكت بأنه: "نوع من الوقف بمفهومه العام، لا بمفهومه الاصطلاحي في علم وقف القرآن؛ وذلك لأنّ السّكت فيه قطع الصوت كالوقف، والفرق بينهما في الزمن، والطريقة، وأداء المعنى، فالسّكت يصحبه تتغيم معين، وزمنه أقل من زمن الوقف، ولا تتفس فيه؛ لأنه لا يدل على تمام المعنى، كما أن حركة الإعراب باقية معه، أمّا الوقف فلا بد فيه من قطع النفس، والزمن فيه حرّ غير مقيد، فقد يطول وقد يقصر، لكنه لا يصل إلى زمن السّّت، كما أنه يدل على كمال المعنى، وفيه كسر الإعراب بإحلال السكون محل

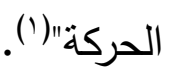

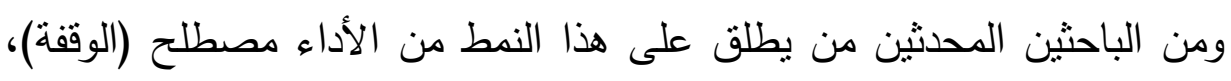

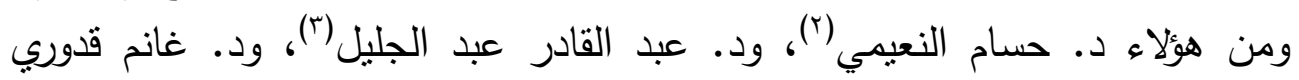
الحمد(؛)، ومنهم من يطلق عليه مصطلح (المفصِل)؛ حيث يقول د. د. أحمد مختار عمر : "الكَفْصِل (juncture) ويسمى (الانتقال): عبارة عن سكتة خفيفة بين كلمات أو مقاطع في حدث كلامي، بقصد الدلالة على مكان انتهاء لفظ ما، أو مقطع ما،

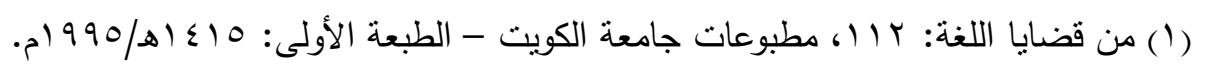

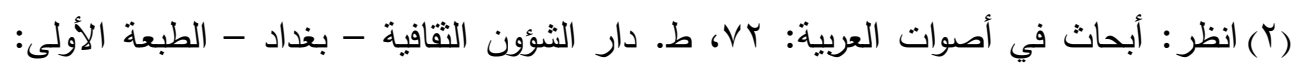
. $991 / / 81 \leq 11$

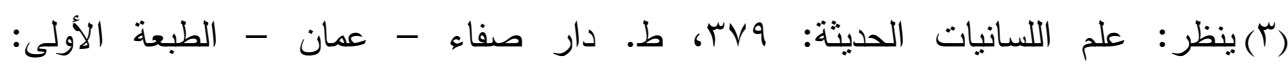
$\cdot r T r / \Delta 1 \leq r t$ (ع) ينظر : المدخل إلى علم أصوات العربية: بهץ ، منشورات المجمع العلمي العراقي - بغداد -

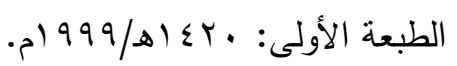


وبداية آخر"(')، وإن كان بعضهم(؟) يطلق مصطلح (المَفْصِل) ليشمل: الوقفات، والسّكتات، والاستراحات.

من خلال ما تقدّم ندرك أنّ (السكت) نوع من أنواع الوقف بين أجزاء الكلام

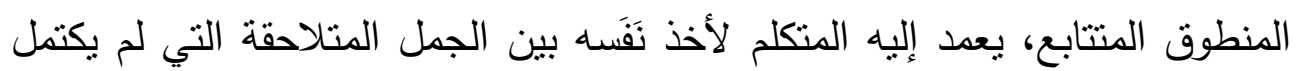

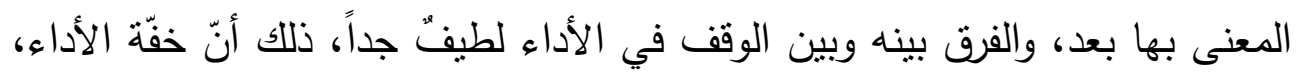
وعدم التتفس، وقلة الزمن التي تميّز (السكت) عن (الوقف) أمور نسبية، لا يمكن

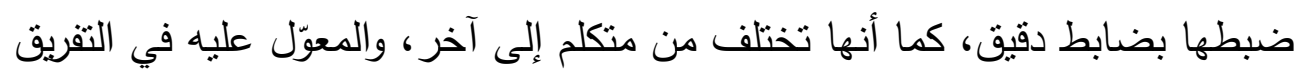
بين (السكت) و (الوقف) هو التتغيم المصاحب للأداء بالسكت، الذي يُشتعر بارتباط

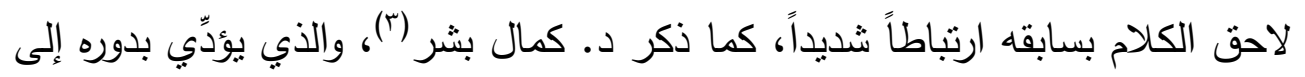
تشكيل المعاني وبلورتها. وعموماً إذا كان السّكت بين أجزاء الكلام المنطوق يمثّل ظاهرة فيزيولوجية ضرورية للناطق؛ لأخذ النَفَس المعين على مواصلة النطق، فإنّ ما يُعنى به البحث

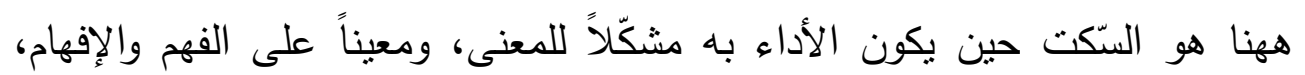
وسبيلاً إلى البلاغة وحسن البيان.

$$
\begin{aligned}
& \text { المبحث الأول } \\
& \text { السّكت في التراث العربي }
\end{aligned}
$$

(1) دراسة الصوت اللغوي: اسب، ط. عالم الكتب-القاهرة- الطبعة الأولى: 9VY ام. وينظر : أسس

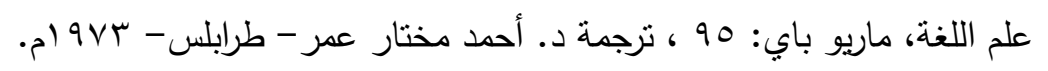
(r) ينظر : الدراسات الصوتية عند العلماء العرب والدرس الصوتي الحديث، دئ د. حسام البهنساوي:

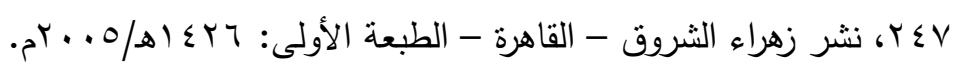

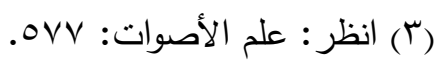




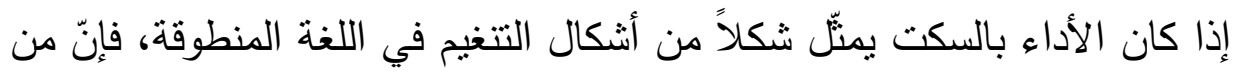

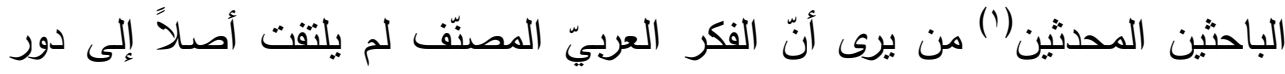

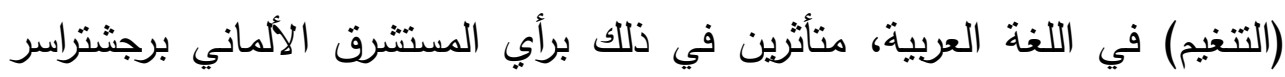

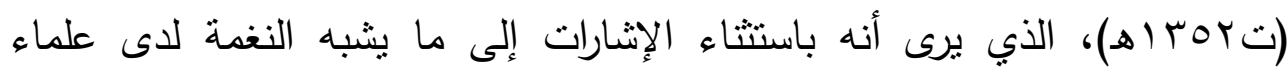
التجويد، فإنه لا يوجد نصّ في التراث العربي يمكن الاستتاد عليه في إجابة مسألة: كيف كان حال العربية الفصيحة في هذا الثأن (广). وإذا كان الأقدمون لم ينصّوا على (التتغيم) كمصطلح في دراساتهم اللغوية،

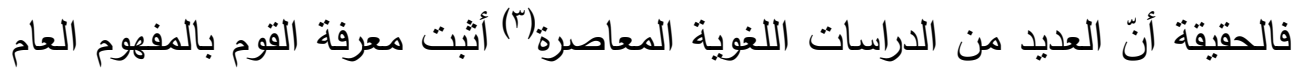

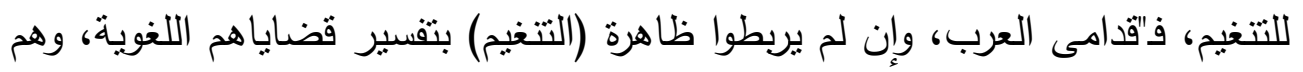

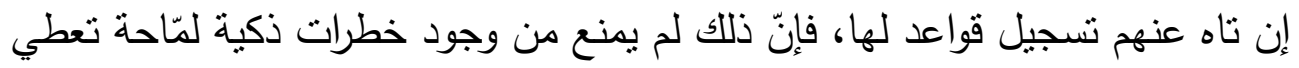

(1) من هؤلاء د. تمام حسان، الذي يرى أنّ العربية الفصحى لم تعرف دراسة التتغيم في قديمها، وأن القدماء لم يسجلوا لنا شيئًا عن هذه الظاهرة، وكذلك برى الباحث محمد الأنطاكي، الذي استتتج

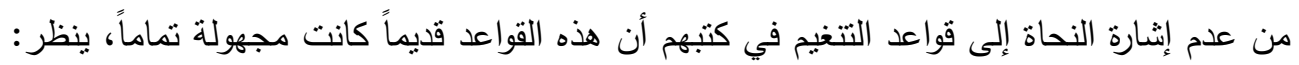

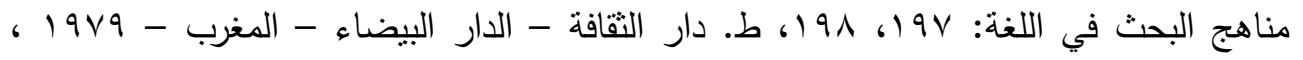
ودراسات في فقه اللغة العربية: Vو ال، ط. دار الثرق العربي - بيروت - الطبعة الرابعة (د.ت).

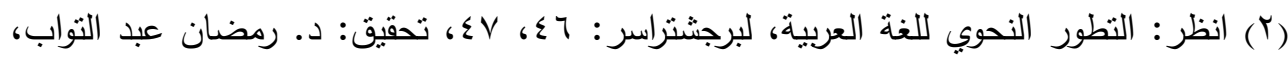

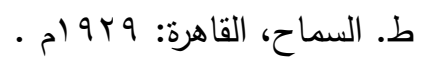
(r) ينظر : من وظائف الصوت اللغوي: محاولة لفهم صرفي ونحوي ودلالي، د. أحمد كثك، ط.

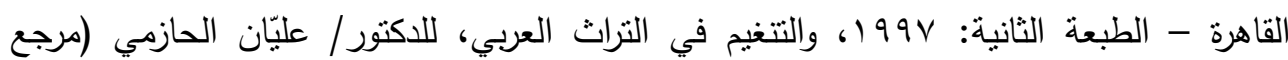

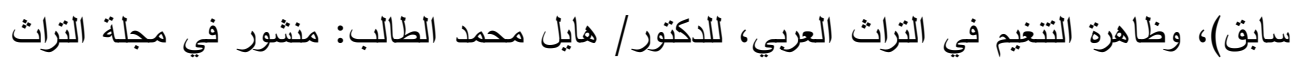

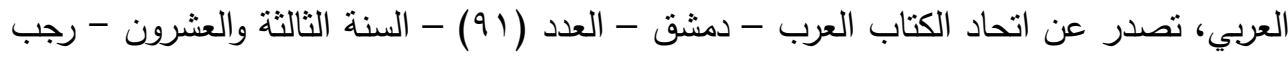

م 
إحساساً عميقاً بأنّ رفض هذه الظاهرة تماماً أمر غير وارد، وإنْ لم يكن لها حاكم من

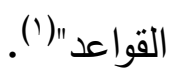

والحقيقة أنّ ما ذهب إليه (برجشتراسر) ومن سار في فلكه من محدثي اللغوبين العرب من أنّ الفكر العربيّ المصنّف لم يلتقت إلى دور (التتغيم) في اللغة العربية الفصيحة لا يمكن قبوله والتسليم به على عمومه، ذلك أنّ بعض الأنماط التتغيمية منل (السّكت) كان معروفاً على مستوى التتظير اللغوي العربي اصطلاحاً، كما كان لهان معروفاً في الواقع اللغوي العربي تطبيقاً واستخداماً؛ وبيان ذلك فيما يلي: أولاً: عُرف (السّكت) كمصطلح في التراث العربي في نطاق علم الأداء والتجويد، على أنّه نمط مباين للوقف في الزمن وطريقة الأداء كما مرّ آنفاً، وإنْ كان غالب المتقدمين من أهل هذا العلم لا يميّز بينه وبين مصطلح (الوقف) أو (القطع)؛ حيث يقول ابن الجزري (ت سrیهـ): "(الوقف)، و (السّكت)، و (القطع)، هذه العبارات جرت

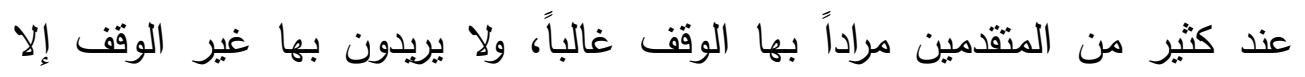
مقيدة"(r)، والتفريق الدقيق بين هذه المصطلحات لم يُعرف إلا عند المتأخرين، كما

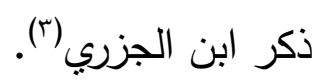

ولم نكن الدراسات البيانية القديمة بمنأى عن إدراك أهمية الفصل بين مقاطع الكلام وحدوده في جودة الإفهام وحسن البيان، سواء في أداء الكلام المنطوق، أو في إن لهن رسم النص المكتوب، حيث عقد أبو هلا العسكري (تهوبه) الباب العاشر من وهن كتابه (الصناعتين) على ذكر (مبادئ الكلام ومقاطعه، والقول في حسن الخروج والفصل والوصل، وما يجري مجرى ذلل)، وفي حديثه عن المقاطع، والفصل

$$
\text { (1) من وظائف الصوت اللغوي: 0V، } 01 .
$$

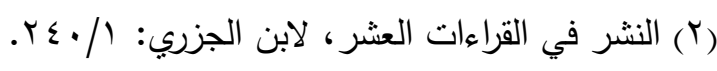

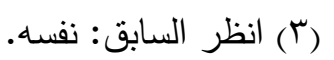


والوصل، ذكر أبو هلا عدة مقولات منسوبة لبعض المعنيين بالبيان في الجاهلية

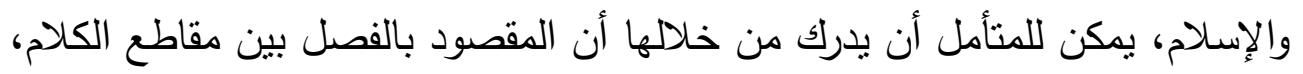

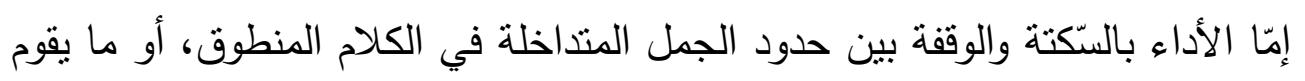

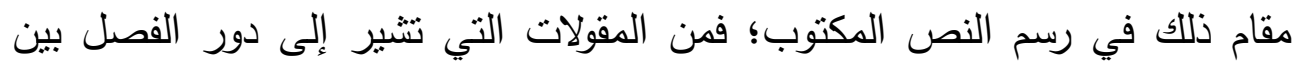
مقاطع الكلام في أداء النص المنطوق، ما يلي:

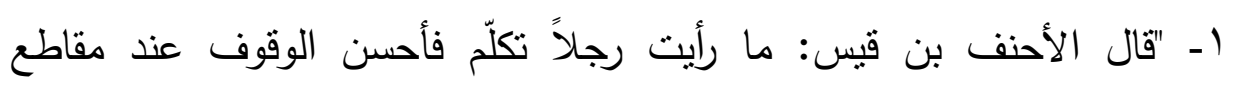
الكلام، ولا عرف حدوده إلا عمرو بن العاص، كان إذا تكلم تفقد مقاطع الكلام.... حتى كان يقف عند المقطع وقوفاً يحول بينه وبين تبيعته من الألفاظ"(') r- "لما أقام أبو جعفر صالحا خطيبا بحضرة شبيب بن شيبة وأنشراف قريش

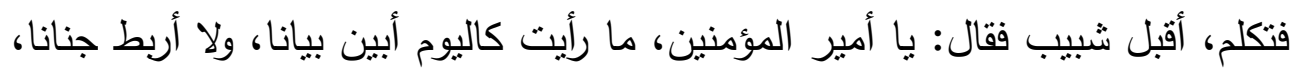

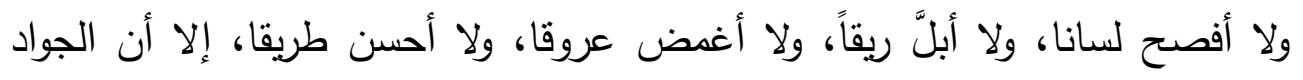

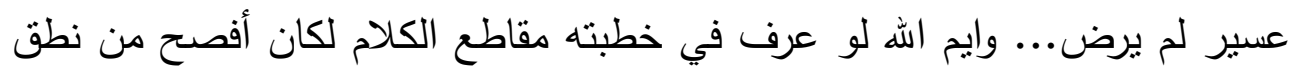

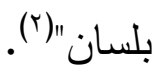

ومن المقولات التي أورها العسكري تثبر إلى أهمية الفصل بين المقاطع في رسم

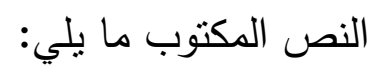
1 - "كان أكثم بن صيفي إذا كانب ملوك الجاهلية يقول لكتّابه: افصلوا بين كل

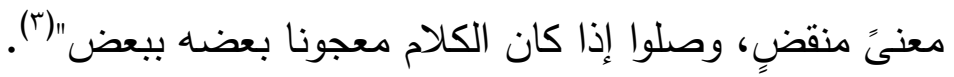
(1) الصناعتين: الكتابة والثعر ، لأبي هلال العكري: 9؟ب، ط. محمود بك - الآستانة - الطبعة

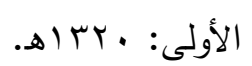

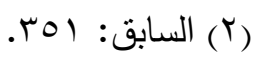

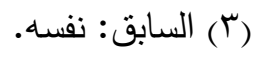


r- "كان الحارث بن أبي شمر الغسّاني يقول لكاتبه المرقش: إذا نزع بك الكلام إلى الابتداء بمعنيً غير ما أنت فيه، فقصِّل بينه وبين تبيعته من الألفاظ، فإنك إن

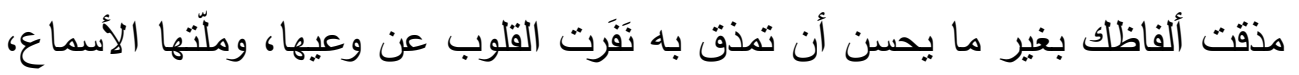

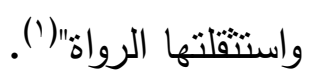
فمن خلا تلك النصوص، ندرك مدى تقدير المعنيين بالبيان العربي قديماً لدور الفصل بين مقاطع الكلام نطقاً وكتابةً، وإن شئت قل: إنهح عُوا بالأداء بـ(السكت: الوقف) كعنصر مايز بين مقاطع الكلام المنطوق، كما ورد في وصف الأحنف بن قيس أداءَ عمرو بن العاص، وإطرائه عليه بأنّه (كان يقف عند المقطع وقوفاً يحول بينه وبين تبيعته من الألفاظ)، كما عُنوا بالتمبيز بين مقاطع الكلام في رسم النصّ المكتوب، وذلك واضح في تتبيهات أكثم بن صيفي الذي أوصى كثّابه بالفصل بين كل معنىً منفضٍ، والوصل إذا كان الكلام معجونا بعضه ببعض، الأمر الذي تطوّر فيما بعد، وتبلور في صورة (علامات الترقيم)، و "هي علامات اصطلاحية توضع بين الكلمات والجمل أو العبارات؛ لتفك الاشتباك الدلالي بينها، ولترشد إلى حدودها الدلالية، ولتتظم العلاقة بينها وتوضحها"(؟)، غير أنّ هذه الإشارات وإن استثمرها البلاغيون في بناء مبحث الفصل والوصل فيما بعد، وفي تصنيف العلاقات بين الجمل التي لا محلّ لها من الإعراب، إلا أنّ هذه الإشارات ونحوها لم ثُدرس على لئ نحو تحليلي واسع ومفصل، كما أنها لم تأخذ حظّّها الكافي من الدراسات الصوتية البيانية لدى المتأخرين من البلاغيين.

(1) السابق: نفسه. (r) الإبهام في شعر الحداثة العوامل والمظاهر وآليات التأويل، د. عبد الرحمن محمد القعود:

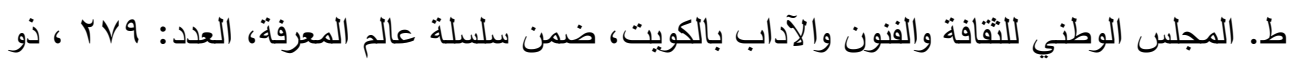

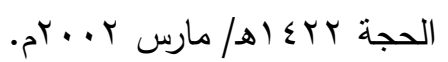


ومن الجدير بالذكر في هذا الصدد أنه في نطاق التصنيف البلاغي لدى المتأخرين في مبحث (الفصل والوصل)، وردت إثنارة لافتة تؤكد على دور الأداء

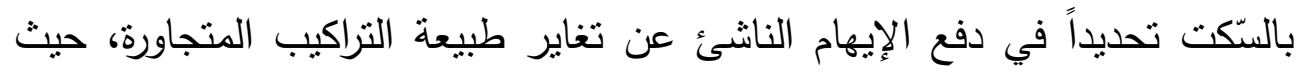

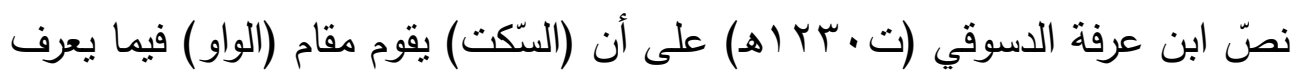

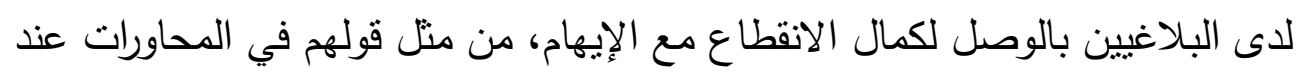

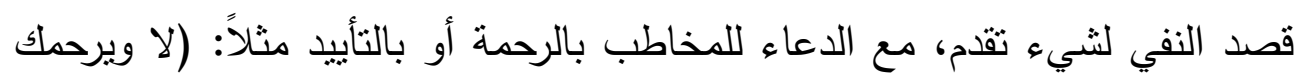

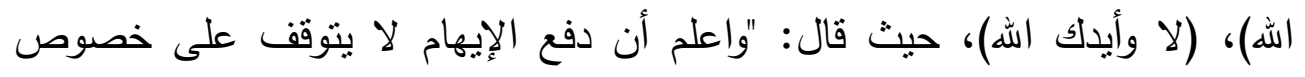

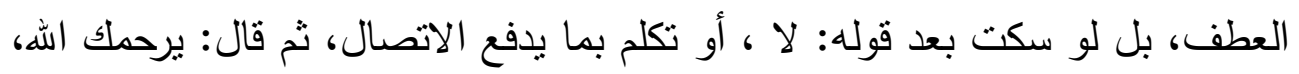

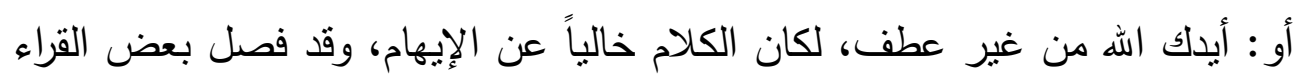

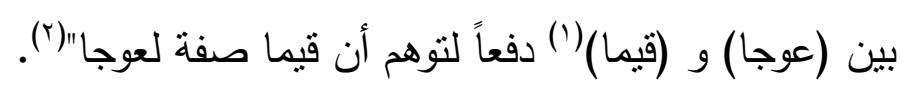

وإذا نأملّت وجدت أنّ نصّ الدسوقي يحوي كلاماً نفيساً بدل على مدى إدراك قائلّه

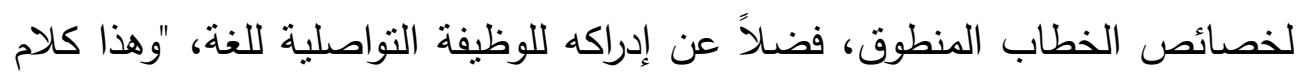

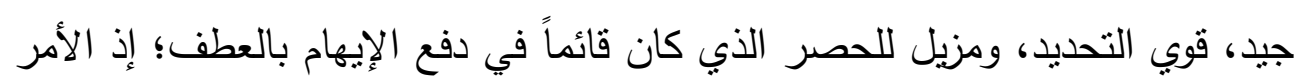

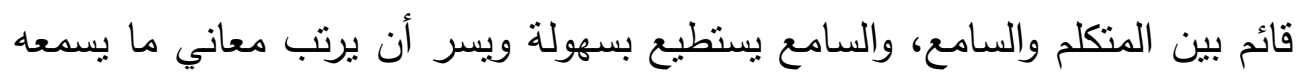

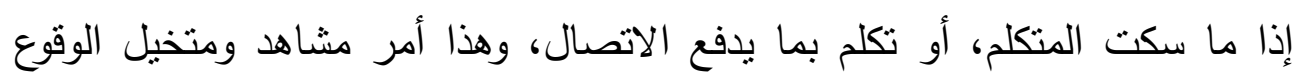
كثيراً (广) (ن)

(1) ينظر تفصيل ذلك في مبحث (النتكت في الأداء القرآني).

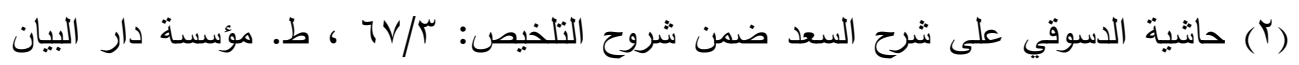

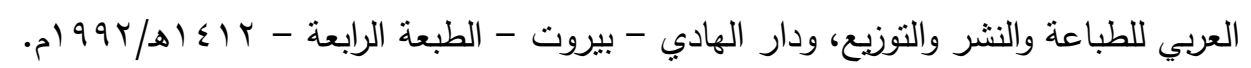

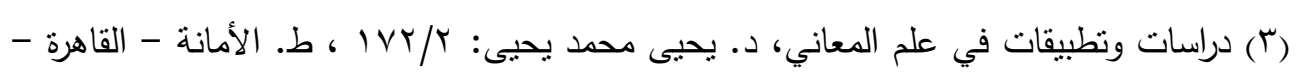

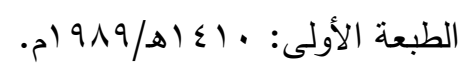


كما تتبّه بعض المتأخّرِين من النحوبين إلى دور (السّكت) في الإفهام النحوي، حيث عقب الثيخ يس صاحب (حاشية شرح التصريح على التوضيح) على توكيد الحرف قائلاً: "الحرف إن كان جوابياً، أو مفصولاً بسكتة، أو باعتراضية، أو بعاطف

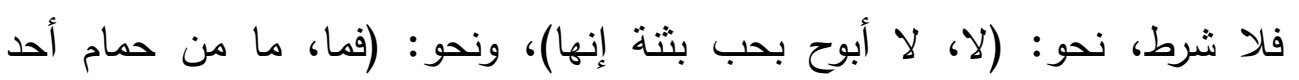
معتصماً)، ونحو: (ليت، وهل ينفع شيئاً ليت)، ونحو: (ليت شعري هل، ثم هل (آنتنهم)" (1)

والحقيقة أنّ تلك الإشارات كان ينقصها ضربة بمعولٍ آخرة حتى تتفجر ينابيعها، ولو أنها نما عودها، وتشعبت فروعها، لآتت أكلها، ولامتدّت إلى ما هو أبعد من لهن (السّكت) من مظاهر الأداء الخطابي، أقول: لو تتبّه المشتغلون بالدراسات اللغوية والبيانية إلى مثل هذه الإشارات وغيرها، لكنّا قد توصّّنا اليوم إلى نظريات لسانية عربية خالصة، سابقة للسانيات الغربية ومتفوقة عليها. ثانياً: أمّا عن الاستخدام، فإنّ الباحث يزعم أن تطبيق مفهوم السكت بين حدود الجمل ومقاطع الكلام كان معروفاً وممارَساً في أداء اللغة العربية قديماً وحديثاً، سواء سمي سكتاً أو وقفاً، بل أقول: إنه لا يُتصوّر أبداً أداء اللغة المنطوقة بدونه، حيث إنه

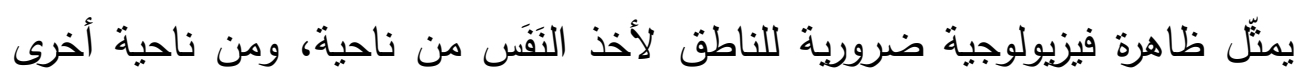
فإنه لا غنى عنه للفصل بين حدود المعاني، وتمييز مقاطع الكلام، وكما يقول د. تمام حسان: "اللغة العربية الفصحى في عصرها الأول ككل لغات العالم، ربما أهمت أن تذكر الأدوات في الجملة اتكالاً على التعليق بالنغمة، فكان من الممكن مثلاً أن

(1) حاثية يس، مطبوع بهامش شرح التصريح على التوضيح، للشيخ خالد الأزهري: r/. با ، ط.

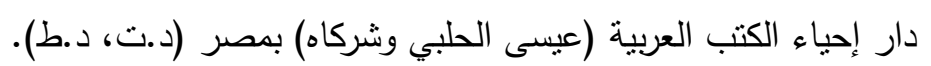


نفهم معنى الدعاء من قولهم (لا وشفاك الله) بدون (الواو) انكالاً على ما في تتغيم الجملة من وقفة واستئناف"(')

لكن توظيف هذا النمط من الأداء في تشكيل المعاني، وفي تحقيق البلاغة والبيان

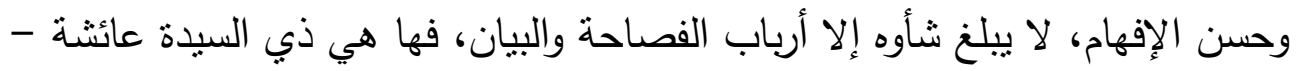

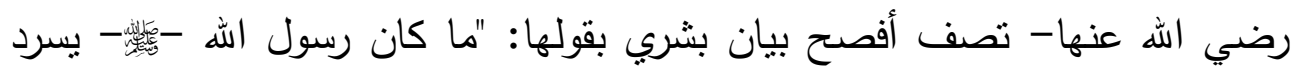

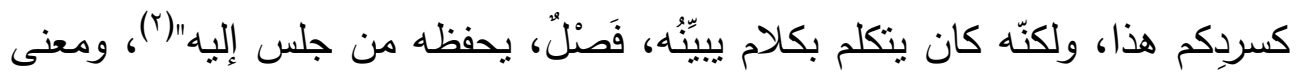

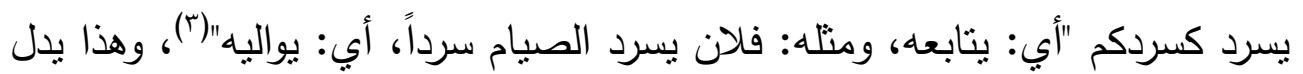

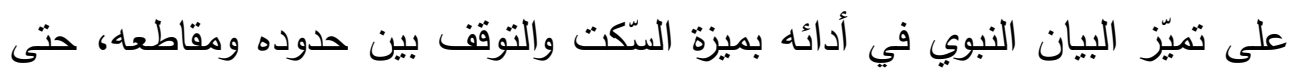

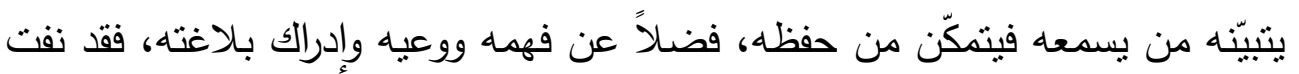

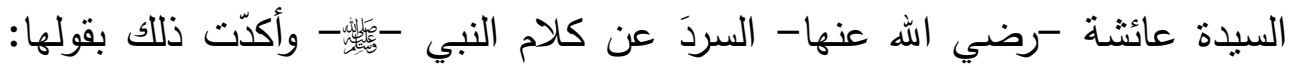

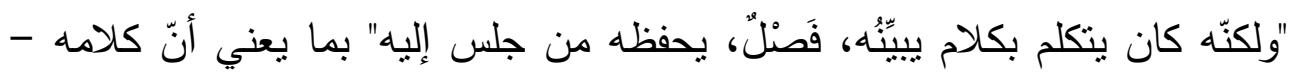

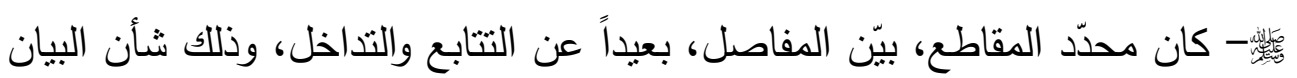
النبوي الرفيع، وشأن كل بيان منطوق يبتغي استمالة القلوب، وجذب الانتباه، وإصغاء

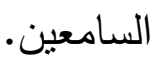

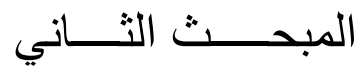

$$
\begin{aligned}
& \text { السّكت و البيان }
\end{aligned}
$$

$$
\text { (1) اللغة العربية معناها ومبناها، د. تمام حسّان: TYV. }
$$

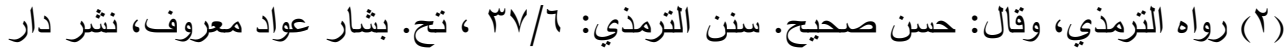

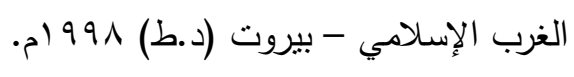

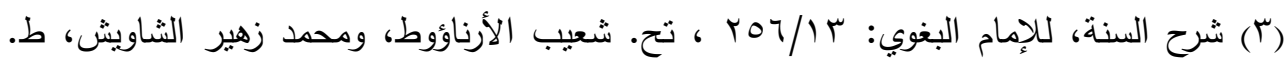

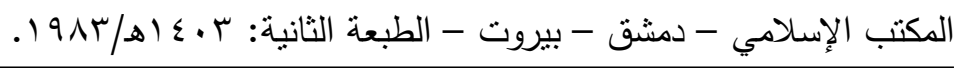


لا شك في أنّ إيصال الرسالة اللغوية واضحة جليّة، دون تداخلٍ يُفضي إلى لبس أو غموض، هو المعنى الأول الذي يتبادر إلى الذهن عند إطلاق لفظة (البيان)، وفي حالاتٍ كثيرة من أداء الخطاب المنطوق، يتوقف فهم المعنى وبيانه على الطربقة الصوتية التي يُؤدّى بها الكلام، وهنا يأتي دور (السّكت) حين يوظفه المتكلم في فضّ الاتتباك بين المعاني المتثاخلة؛ ليحقّق به لسامعه الإفهام وحسن البيان. وممّا يبرهن على أهمية الأداء بالسّكت، ويُييّن دوره الحيوي في العملية البيانية، أنّ المعنى أحياناً قد يغمض على السامع أو يلتبس عند أداء التراكيب المتداخلة دونما سكت بين حدود مقاطعها، وإن شئت فتأمل ما وقع فيه الكسائي (ت9 1 ( هـ) من خلط في فهم المعنى النحوي وتوجيهه؛ بسبب غياب هذا النمط من الأداء، عندما "سأل من

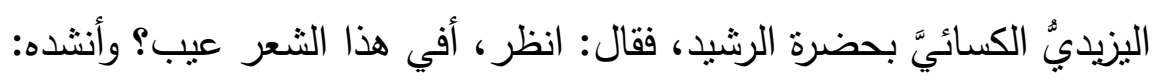

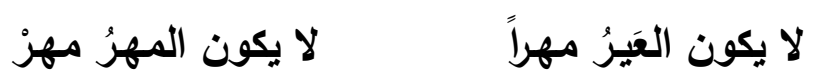

فقال الكسائي: قد أَقْوى الثاعر، فقال له اليزبدي: انظر فيه! فقال: أقوى؛ لابدّ أن ينصب (المهر) الثاني على أنه خبر لـ (يكون)، فضرب اليزبديّ بقلنسوته الأرض،

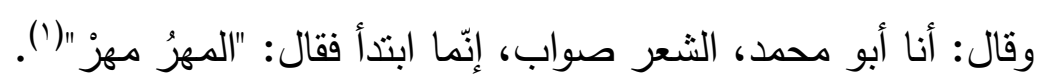
فمن الواضح في هذه الواقعة، أنّ اليزبدي كان بصدد الإيقاع بالكسائي في حضرة الرشيد؛ لإثبات تفوِّق ما، ومن ثَّْ أَلبس على الكسائي نركيب البيت، مما جعله يتوهّم

(1) الأشباه والنظائر، للسيوطي: ب0/ץ ب ، تح. إبراهيم محمد عبد الله، منشورات مجمع اللغة العربية بالقاهرة، ج19 ام. والخبر مذكور في ترجمة: علي بن حمزة الكسائي، في معجم الأدباء،

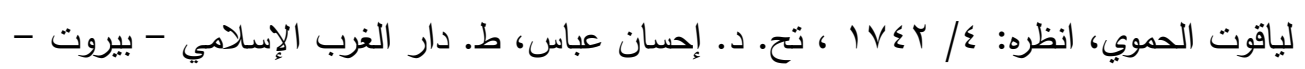

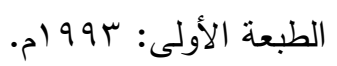


أنّ فيه عيباً من عيوب القافية هو : (الإقواء) (')؛ لأن البيت قبله مبني على فتح حرف

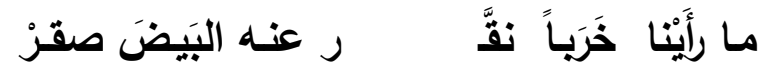

وبيدو أنّ وسيلة (اليزيدي) للنيل من منافسه (الكسائي) كانت بأداء البيت دونما

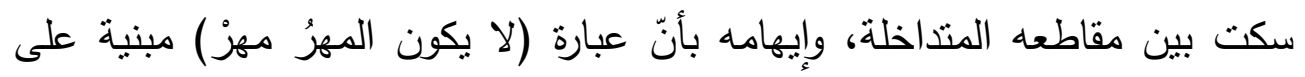
جملة واحدة، من مضارع (كان) المنفية مع اسمها وخبرها، وهذا غبر صحيح، لأنّ بهان التركيب مكون من جملتين، أولاهما: جملة (لا يكون)، والأخرى: جملة (المهر مهر) الاستئنافية، وعلى هذا فإن (مهر) الثانية حقها الرفع، لا النصب، حيث يقول ابن هشام الأنصاري (ت (IVAه): "رفعت-يعني مُهر الثانية- على أنها خبر لـ(مهر)، و (لا يكون) تأكيد للأولى، وقوله: (المهر مهر) كلام مستجد"(r)، ولأن التقريق بين النمطين من التراكيب لا يكون إلا بأداء الأولى مفصولة بسكتة عن الثانية، حدث ما

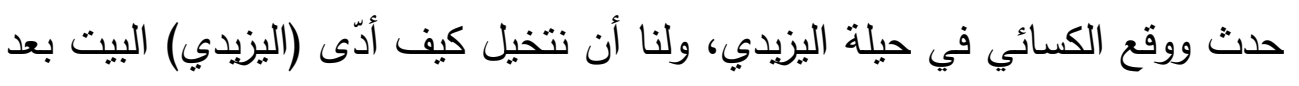
ذلك بالسّكت موضحاً طبيعته التركيبية، وهنا يمكن القول بأنّ اليزيدي "استخدم شيئًاً جديداً في تفسير البيت وهو السّكتة، أو قل: الوقفة، أو قل: التتغيم، الذي جعل جملة (لا يكون) التي ضغط عليها حين النطق، وأخذت مطاً صوتياً لم يعهد لها بعيداً عن

(1) الإقواء: هو اختلاف حركة الروي في قصيدة واحدة، انظر: الكافي في العروض والقوافي،

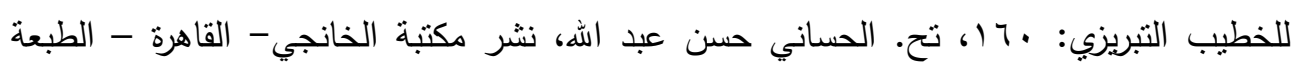

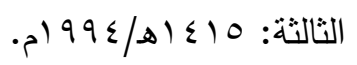

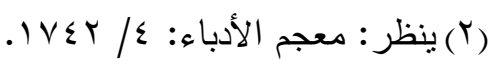

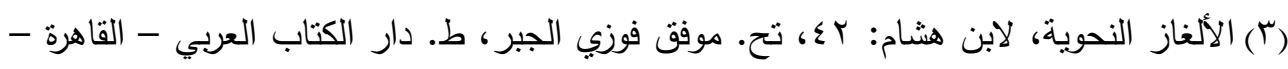

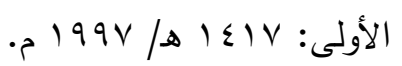


هذا السياق، لا صلة بينها وبين ما بعدها فهي توكيد لما قبلها من حديث"(()، وهذا يؤكد على ضرورة الأداء بالسّكت بين حدود التراكيب المتداخلة؛ لإبراز طبيعتها التركيبية، ولتجنيب السامع الخلط في فهم معانيها.

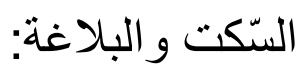

ارتبط مصطلح (البلاغة) منذ ظهوره بالدلالة على حسن الكلام، وتبليغه تمام مقصود المتكلم لدى السامع، فالبليغ هو من يصنع كلامه معبراً عمّا في صدره، فيبلغ به غايته من متلقيّه بأيسر طريق وأحسن تعبير ، وهذا المفهوم نابع من الدلالة اللغوية للفظ نفسه؛ حيث إن مادة (بلغ) في المعاجم العربية تدور على وصول الثيء إلى غايته ومنتهاه(r)، ومن ثمّ سميت البلاغة بهذا الاسم؛ لأنها "تتهى المعنى إلى قلب

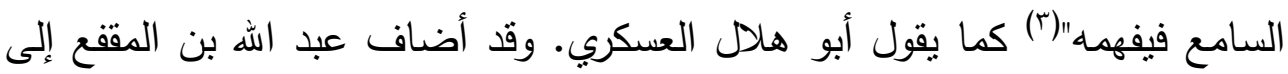
مفهوم البلاغة بعداً جديداً عندما أشنار إلى عدة وجوه تجرى البلاغة فيها ومن خلالها، وذللك بعدما سئل: ما البلاغة؟ حيث قال: "البلاغة اسم لمعانٍ تجري في وجوه كثيرة، منها ما يكون في السكوت، ومنها ما يكون في الاستماع، ومنها ما يكون شعراً، ومنها ما يكون سجعاً، ومنها ما يكون خطباً، وربما كانت رسائل، فعامة ما يكون في هذه الأبواب فالوحي فيها والإشارة إلى المعنى..."(؛). ونكان وليس بين البلاغة والبيان بمفهومهما العام كبير فرق في الفكر العربي قبل السكاكي. وقد أشار البحث آنفاً إلى أنّ مصطلح (البيان) استخدم مرادفاً للفصاحة،

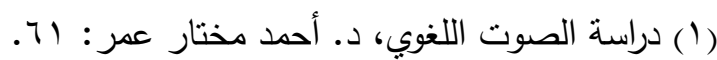

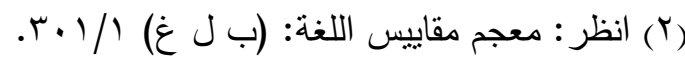

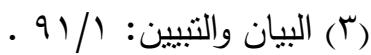
(ع) الصناعتين: 7 . 
والبلاغة، والبراعة لدى الإمام عبد القاهر ، في "وصف الكلام بحُسن الدلالة، وتمامها

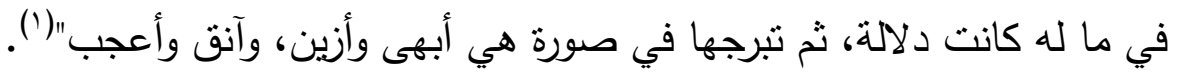
والبلاغة بمفهومها الاصطلاحي ترتبط بكل من طرفي العملية الاتصالية: المتكلم (المرسل)، والسامع (المستقبل) على حد سواء، حيث عرّف الخطيب القزويني بلاغة

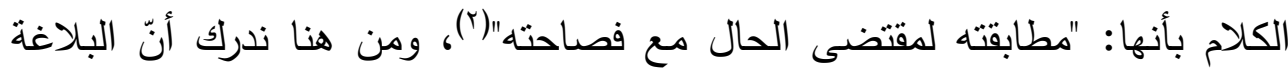

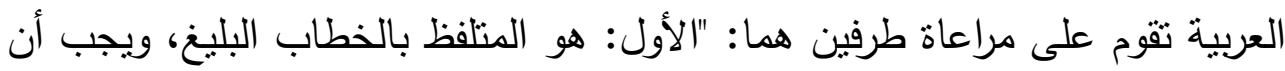

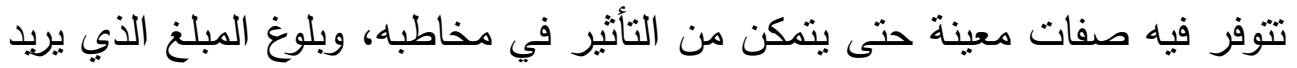
منه، والطرف الثاني: هو المتلقي للخطاب المبثوث في شكل رسالة سليمة وبليغة

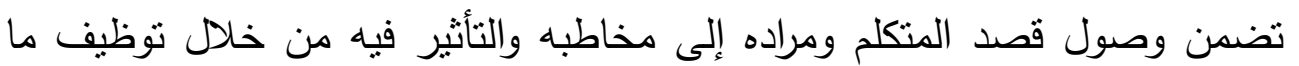
يناسب من أدوات اللغة وتراكيبها"("). وإذا كانت البلاغة تقوم على كل من المتكلم والمخاطب على حد سواء، فإنه من إنه

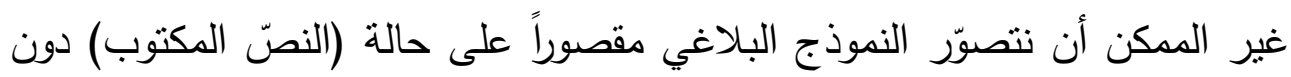

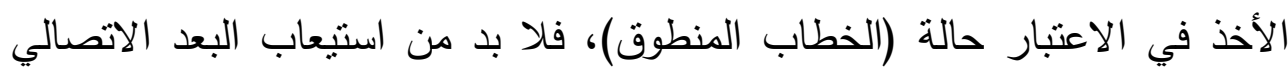

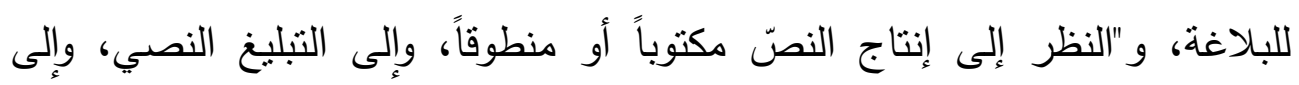

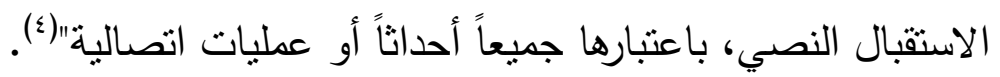

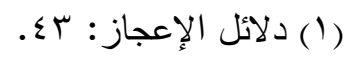

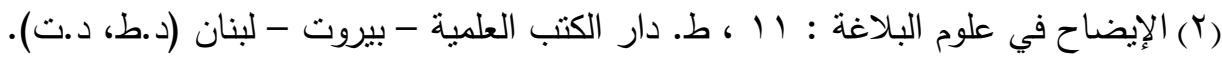

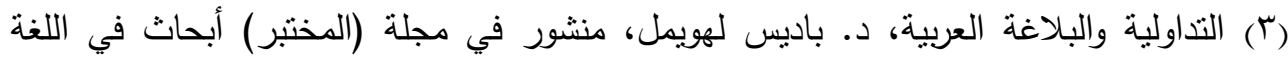

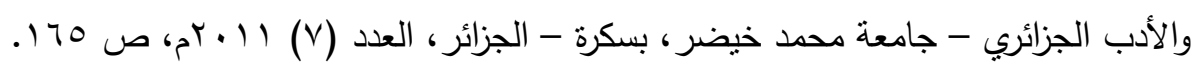

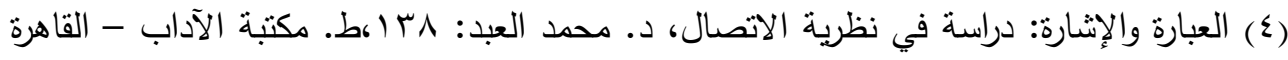


وممّا لا شك فيه أنّ البلاغة كما تتحقق بنظم الكلام وهيئات نراكيبه، من حذف وذكر ، وتقديم وتأخير ، وتعريف وتتكير ، ووصل وفصل...إلخ، فإنها تتأكد بالكيفيات

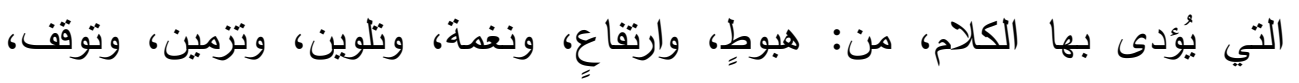
وسكت...إخ. وقد أعجبني كثيراً كلام العلامة الثيخ محمد الطاهر بن عاشور (ت (ت ب اهـ)، حيث قال في مقدمة تفسيره (التحرير والتتوير): "إنّ بلاغة الكلام لا تتحصر في أحوال تراكيبه اللفظية، بل تتجاوز إلى الكيفيّات التي تؤََّّى بها نلك التراكيب؛ فإنّ سكوت المتكلم البليغ في جُمَلِه سكوتاً خفيفاً، قد يفيد من التشويق إلى

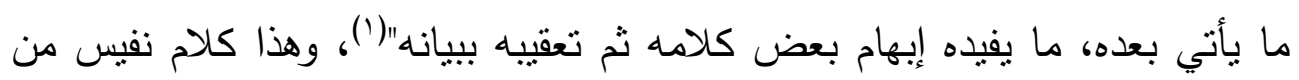
عالم نحرير ، وهو وثيق الصلة بمدار البحث وغايته.

والسّكت بين حدود الجمل المتعاقبة عند النطق بها يؤدي أحياناً دوراً حيوياً وفاعلاً في إدراك الأثر البلاغي لتراكيب تلك الجمل، فمثلاً في التراكيب المبنية على بلى الاستئناف البياني، كقولك: (أحسنتَ إلى زيدٍٍ، زيدٌ حقيق بالإحسان) (؟)، فإنّ السّكت على (زيد) في الجملة الأولى من شأنه أن يعزّز الأثر البلاغي للاستئناف من الترثّب والتشوق في نفس السامع؛ لكون الجملة الثانية (زيدّ حقيق بالإحسان) بمثابة الجواب لسؤال اقتضته وأثارته الأولى. وأحسب أن هذا النمط من الأداء له موقعه الجيد من البلاغة؛ ذلك أنّ المتكلم باستخدامه لهذا الأسلوب القائم على الإيضاح بعد الإبهام، يعبّر عن متابعته لفكر لهن المخاطب، ومراقبته لخلجات نفسه ووثبات حسّه. وإذا كان الخطيب القزويني قد أجمل بإِ سرّ بلاغة هذا الأسلوب في قوله: "وتنزيل السؤال بالفحوى منزلة الواقع لا يصار إليه

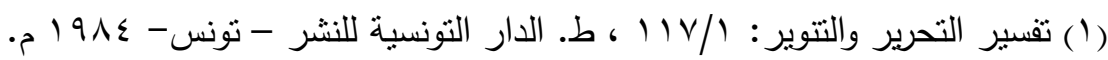

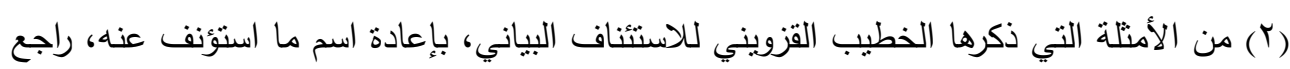

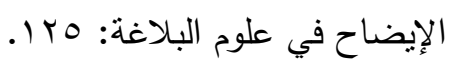


إلا لجهات لطيفة؛ إما لتنبيه السامع على موقعه، أو لإغنائه عن أن يسأل، أو لئلا يُسمع منه شيء، أو لئلا ينقطع كلامك بكلامه، أو للقصد إلى تكثير المعنى التهات التقليل

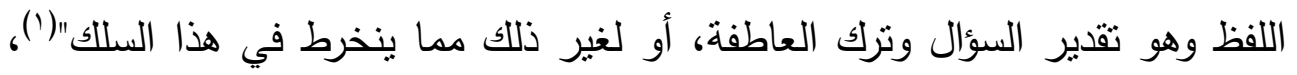

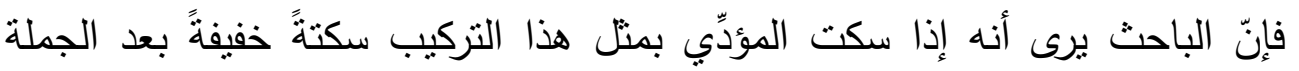

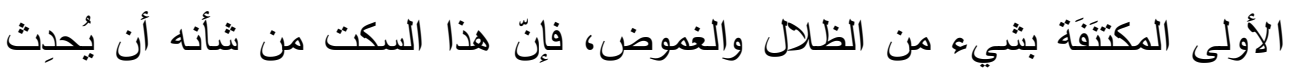
مزيداً من الإثارة والتزقب والتطلّع في نفس السامع، حتى إذا جاءه الجواب في الجملة

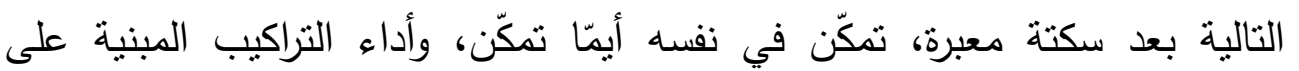

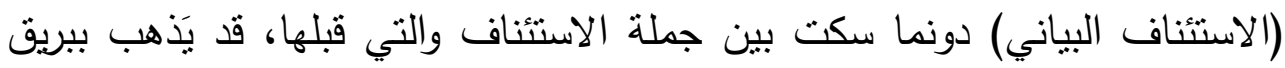

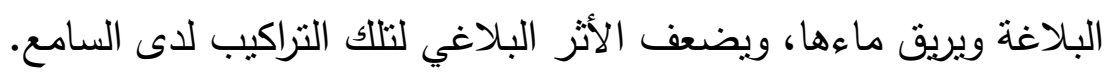
ونلحظ في معظم الأبيات الثعرية المبنية على الاستئناف البياني، أنّ جملة

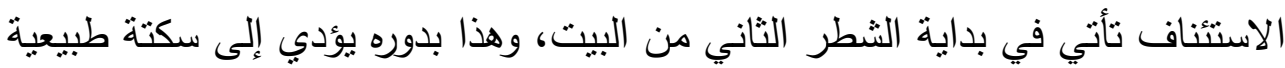

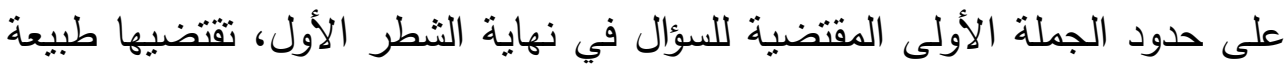

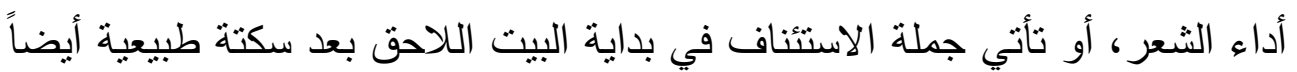

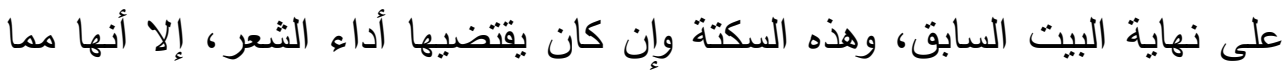
يزيد من فعالية الأثر البلاغي لهذا النمط من التراكيب، فمثلاً في قول المتنبي:

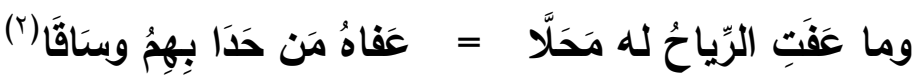

بُني البيت على الاستئناف البياني في شطره الثاني، ذلك أنّ الثاعر عندما قال: (وما

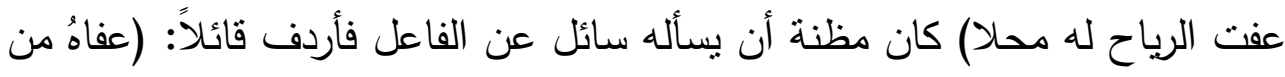

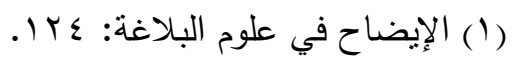

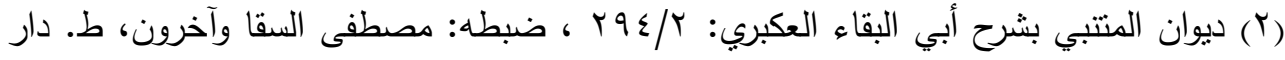

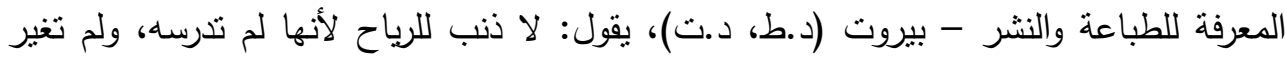

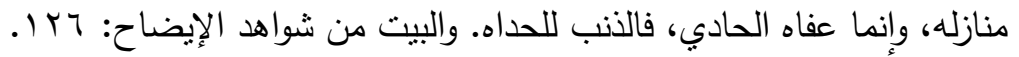


حدا بهم وستاقا)، ويزعم الباحث أنّ السكتة الطبيعية بين شطري البيت لها دور كبير في تحقيق الأثر النفسي للاستئناف، وفي إدراك قيمته البلاغية.

ومن أمتلة مجيء جملة الاستئناف في بداية البيت اللاحق، قول الثاعر ('):

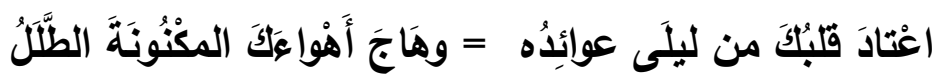

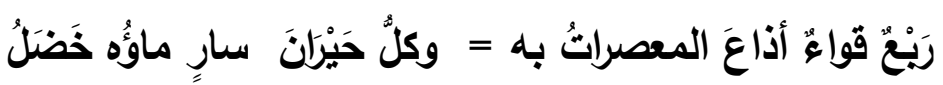

فلما ذكر الثاعر في البيت الأول أنّ الطلل قد هاج أهواءه المكنونة، أدرك تشوق نفس السامع إلى معرفة خبر هذا الطلل وصفته، فاستأنف حديثًا عنه في البيث التالي، وبنى الكلام على حذف صدر الاستئناف وهو المسند إليه، فقال: (ربع قواء أذاع المعصرات بـ). ونظيره كثير في بناء الثعر، مما بقطع فيه الثعراء كلامهم ويستأنفون معاني أخر مبنية على حذف صدر الاستفهام.

وهذه الصورة من صور بناء التراكيب في الثعر العربي أثنار إليها الإمام عبد القاهر، حيث قال: "ومن المواضع التى يطرّد فيها حذف المبتدأ (القطع والاستئناف)، يبدأون بذكر الرجُل، ويقدّمون بعض أمره، ثم يدَعون الكلام الأول، ويستأنفون كلاماً آخر ، وإذا فعلوا ذلك أتوا فى أكثر الأمر بخبر من غير مبتدأ"(r)، واستشهد عبد القاهر لهذه الصورة من صور الحذف بشواهد عدة، وذكر أنّ لها من اللطف والظرف الكثير، حتى صار الحذف فيها قلادة الجيد، وقاعدة التجويد(؟). كما أشار الإمام إلى أن

(1) الييتان من شواهد دلائل الإعجاز : 7ـ ( ـ قال الثيخ شاكر في التحقيق: نسبهما البغدادي لعمر بن أبي ربيعة، وليسا في ديوانه.

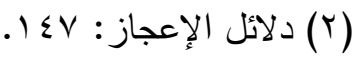

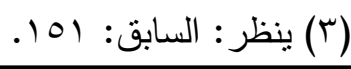


حذف المبتدأ فى هذا الموضع أجمل ما تراه فى ذكر الديار، وفى مقام المدح'(')

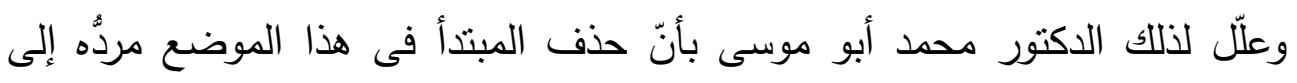
امتلاء النفس، وشدة التأثر بالمعنى (؟).

ويرى الباحث أنّ هذا النمط من البناء التركيبي من شأنه أن يستقطب المتلقي،

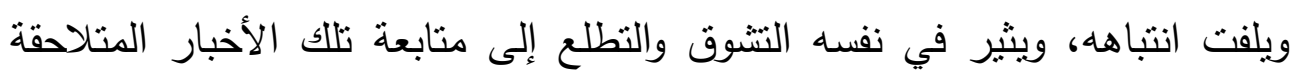

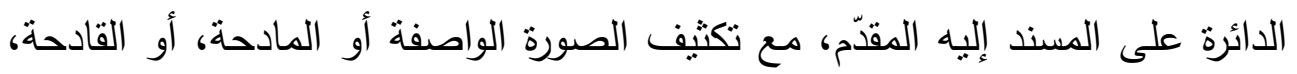

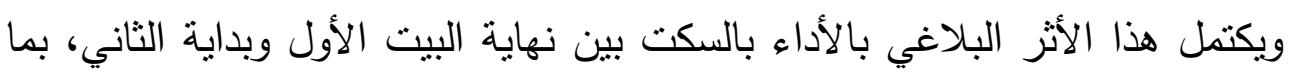

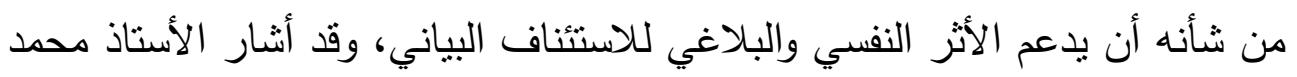

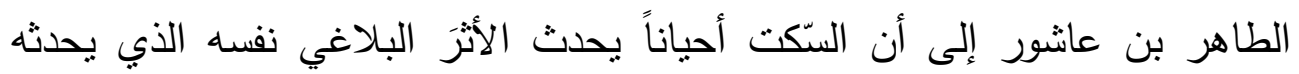

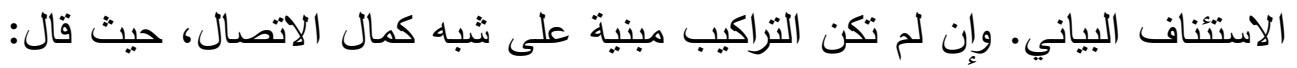

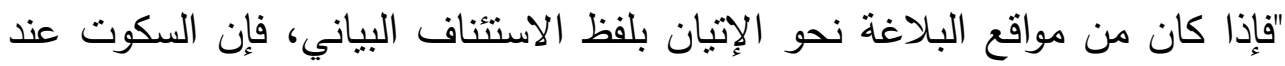

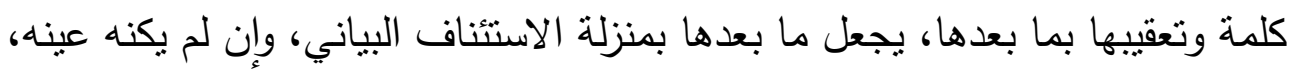

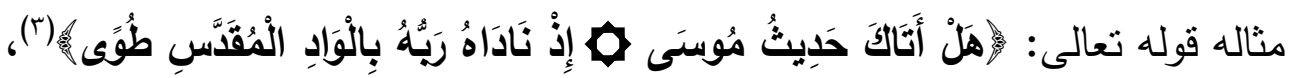

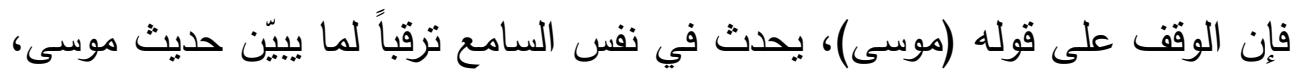

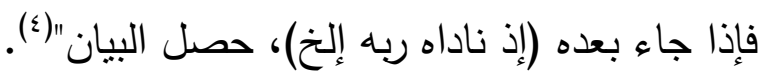

ويدرك البلاغيون في بحث العلاقات بين الجمل أنّ ثثّة تبايناً في طبيعة الدلالة بين الجملتين: الخبرية والإنشائية، هذا التباين يجعل العلاقة بين الجملتين منقطعة

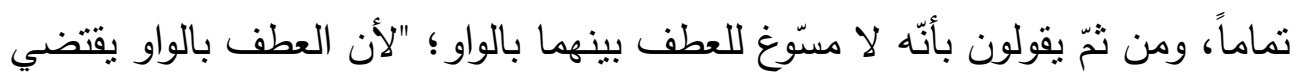


كمال المناسبة بينهما، والمناسبة تتافي كمال الانقطاع"(')، وسواء أكان التباين لفظاً ومعنى، أم كان معنى فقط، فلا مسوغ لعطف إحداهما على الأخرى؛ لأنّ البون

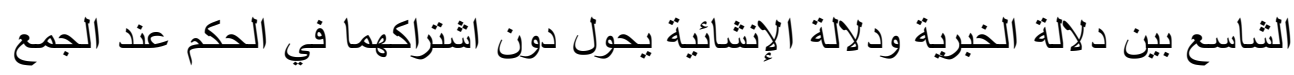
بينهما بالواو -

وفي صورة من صور التراكيب المختزلة، يؤدي التجاور بين الجملتين: الخبرية والإنشائية إلى تداخل نصي، قد يفضى أحياناً إلى معنى مناقضٍ لما يريده المتكلم، وتتحقق هذه الصورة عندما تختلف الجملتان خبراً وإنشاءً، ويكون الفصل بينهما بترك العاطف موهماً لخلاف المقصود، وهو ما يعرف بلاغياً بالفصل لكمال الانقطاع مع

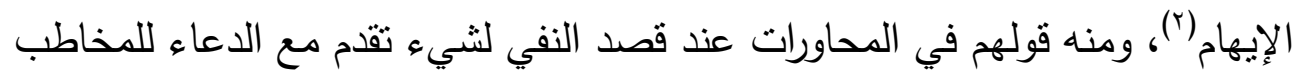
بالتأييد: (لا أيّدك اله)، فقولهم: (لا)، نفي لمضمون كلام مخبر به، أو مسئول عنه، كأن يقال: أنت أسأت إلى فلان، فيقال: لا، أي ما أسأت إليه، ويقال: هل الأمر كما زعم فلان؟ فيقال: لا، أي ليس الأمر كما زعم. وقولهم: (أيدك الله)، جملة إنشائية معنى؛ لأن فحواها الدعاء للمخاطب، فلو أدى المتكلم الجملتين هكذا (لا أيدك الله) دونما تمبيز بين حدود الخبرية المنفية منهما (لا)، والإنشائية معنى (أيدك الله)، لتُوُهّم عكس ما يريده المخاطب؛ لأن النفي بـ (لا) متصلاً بجملة الدعاء الإنثائية (الخبرية

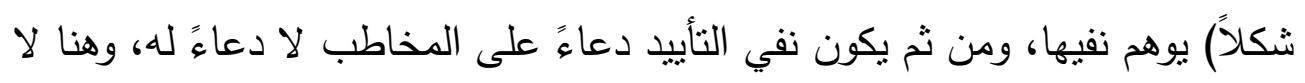
بد من الوصل بالواو (لا وأيدك الله)، أو يكون الأداء بالسّكت بين (لا) و (ائّك الله) هو السبيل لتحقيق البيان في هذا النمط من التراكيب.

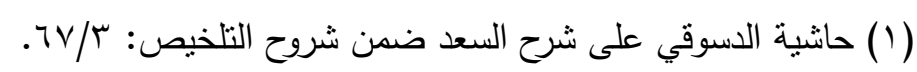

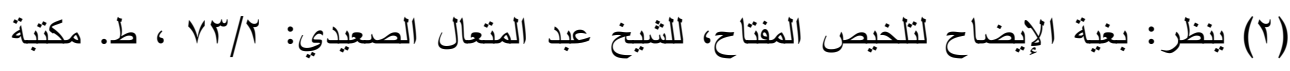

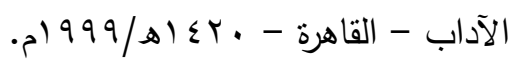


ولأنّ مدار أمر البلاغة على البيان وحسن الإفهام، ألحق بعض الدارسين كمال

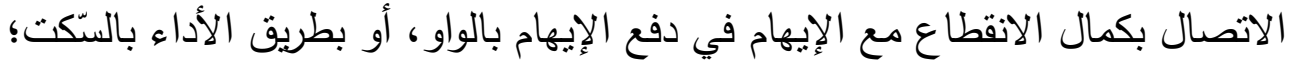

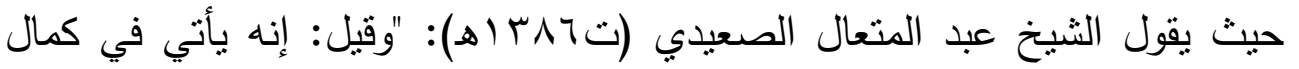

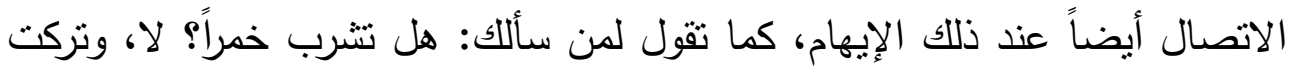
شربه، وقيل: إنه يتعين الفصل في منل هذا، ويدفع الإيهام بطريق آخر فيقال مثنلاً:

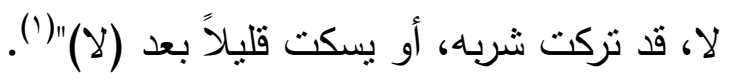

وهناك من التراكيب التي عدّها البلاغيون غاية في الحسن والبلاغة، ما لا يُتصور

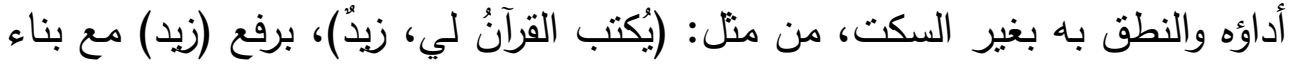

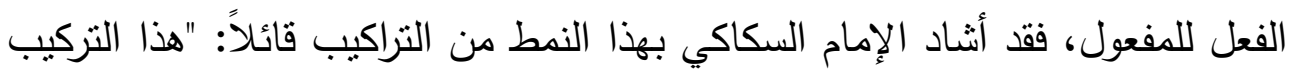

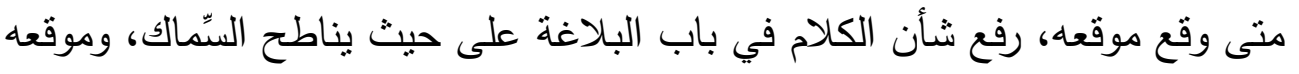

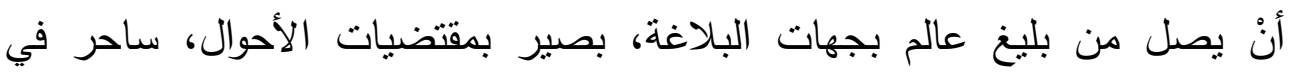

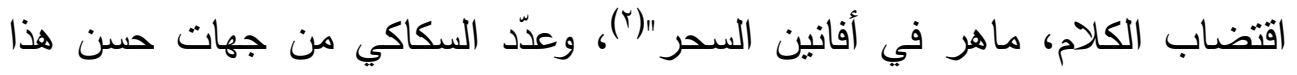

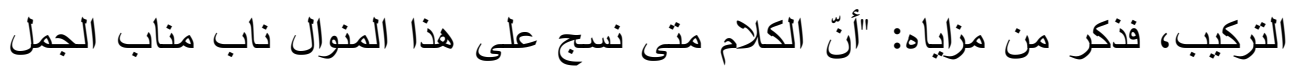

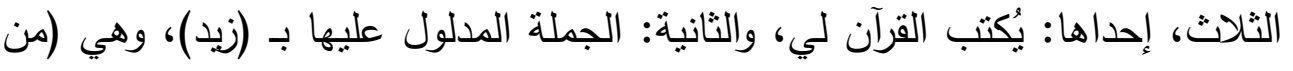

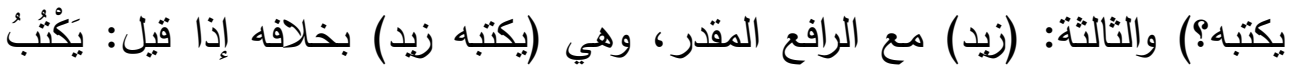

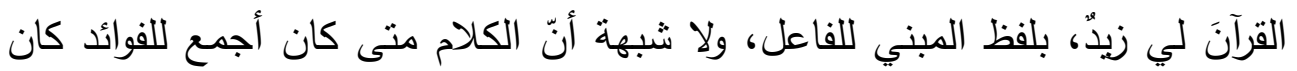

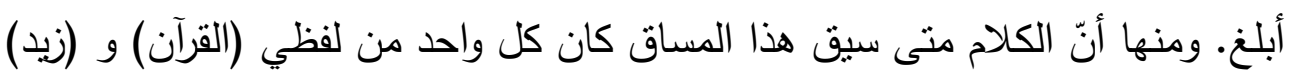

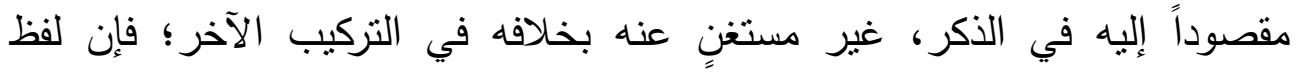

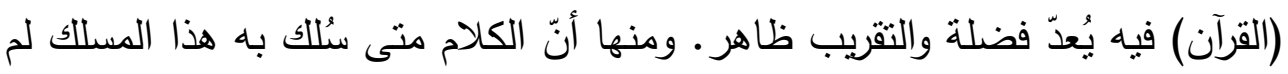

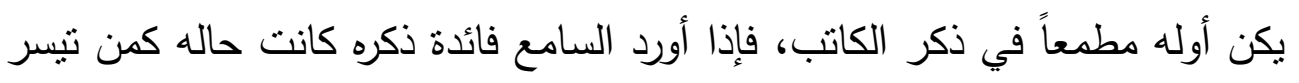


له غنيمة من حيث لا يحتسب بخلافه في النظم. ومنها أنّ الكلام على ذلك النظم يكون كالمتتاقض من حيث الظاهر؛ لأنّ كون القرآن مفعولاً فضلة فيه يكون مؤذنا بأنّ مساس الحاجة إليه دون مساس الحاجة إلى الفاعل، وكونُه مقدّاً على الفاعل

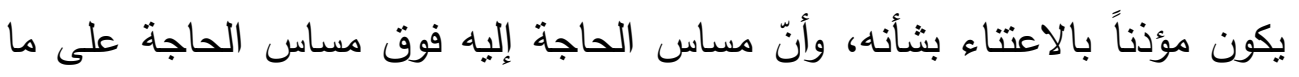

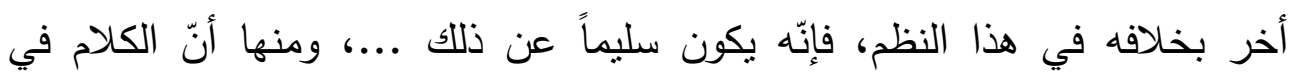
التركيب الذي نحن فيه يفيد استتادا الكتبة على الفاعل إجمالاً أولاً، وتقصيلا ثانياً، وفي غيره يفيد استتادها إليه من وجه واحد، فيكون هذا التركيب أبلغ"('). أقول: إن مثل هذا التركيب الذي تعددت مزايا بلاغته إذا لم يؤد بسكتة خفيفة بين

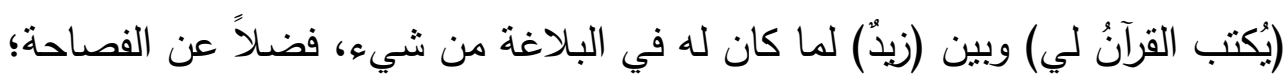
لأنه بدون السكت سيؤدي تداخل الجملتين إلى شيء من الإبهام واللبس. أقول: إنّ منتل هذه التراكيب التي أثاد البلاغيون بقيمتها البلاغية العالية يمثل السكت فيها عنصراً رئيساً ومهماً في إدراك بلاغتها، وفي تحقيق أثرها لدى السامع. وممّا هو متصل بدور السّكت في الإدراك البلاغي أداء الجناس التام المركّب، حيث يتّق اللفظان في أنواع الحروف، وأعدادها، وهيآتها، وترتيبها، مع كون أحد

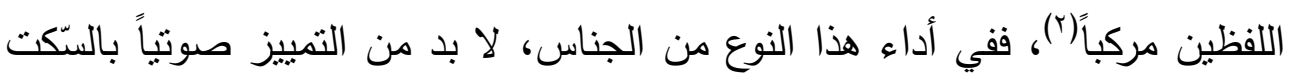

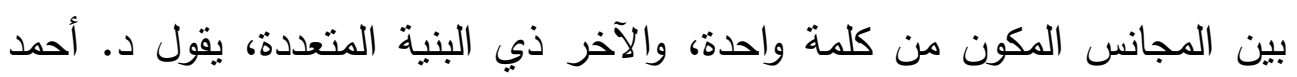
كثنك: "إنّ البلاغيين قد تصوروا فيما درسناه من نماذج الجناس أن هناك اتفاقاً لفظياً تاماً، في الموقف الذي يؤكدون فيه وجود خلاف في المعنى، ولو سألوا أنفسهر: ما الذي أظهر ذلك الخلاف في المعنى؟ لكان من الطبيعي أن يُرَّد أمره إلى أن هنالك قيماً صوتية في التزكيب يعرف المعنى على أساسها، ولو لم يكن هناك من وجود لهذه 
القيم الصوتية لحثث ما تخشاه اللغة، وترفضه عملية الكلام، وهو اللبس والغموض"(")، فمثلاً، في المثال الثهير الذي يستشهد به البلاغيون للجناس التام

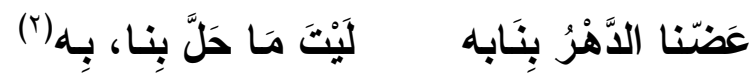

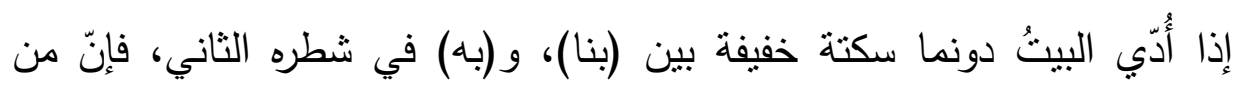

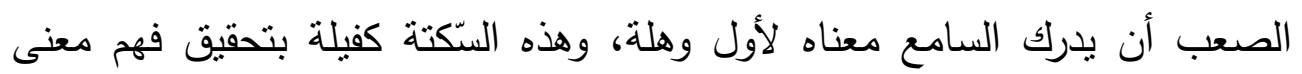

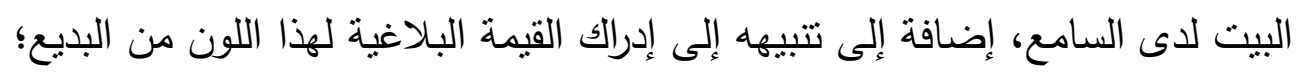
حيث يتحقق لدى السامع "حسن الإفادة، مع أنّ الصورة صورة الإعادة"("). ومن الجدير بالذكر هنا أنّ المفسرين الذين عُنوا بالتفسير البياني للقرآن الكريم، اعتمدوا كثيراً على الوقف بمعناه العام في التوجيه البلاغي للتراكيب القرآنية، فضلاًا

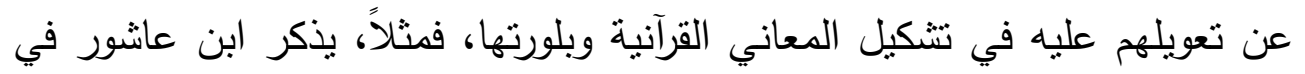

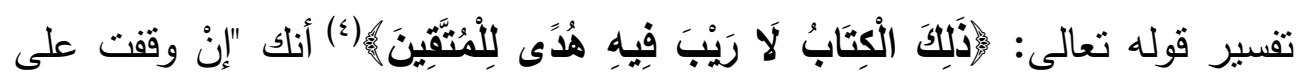

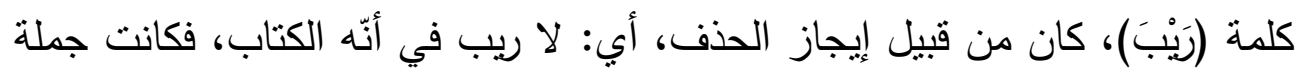

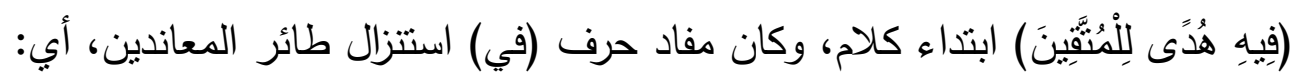

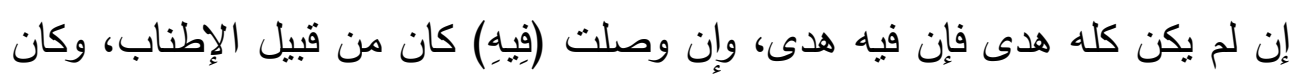

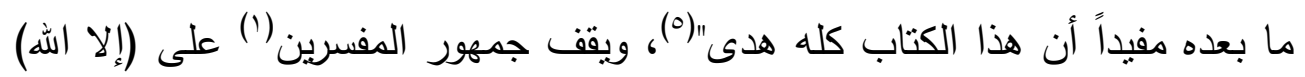

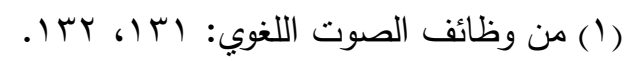

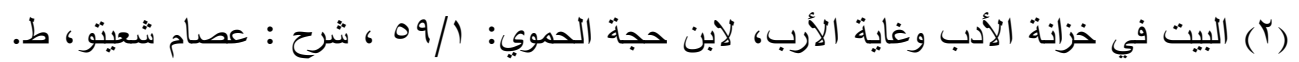

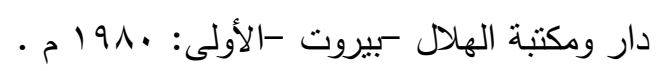

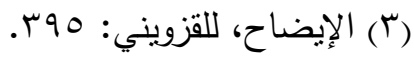

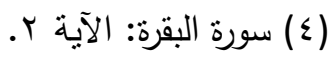

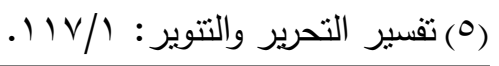




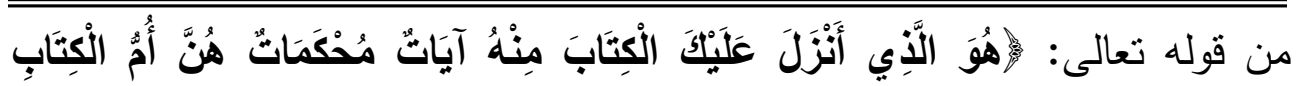

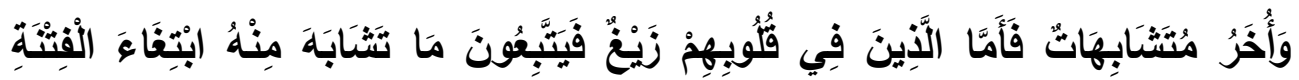

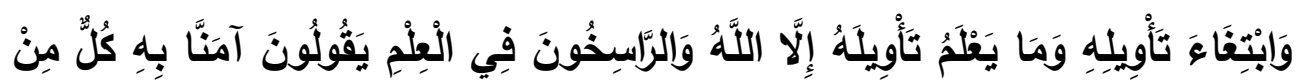

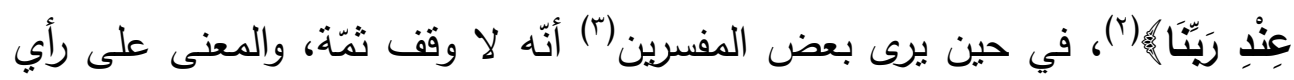
الجمهور : أن اله -تعالى - أنزل القرآن الكريم فيه الهحكم الواضح والمنتشابه، وأنّ أهل

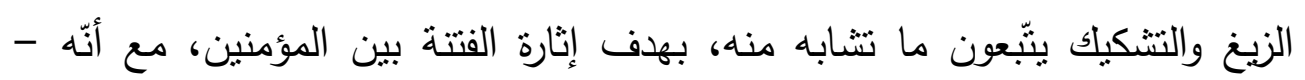

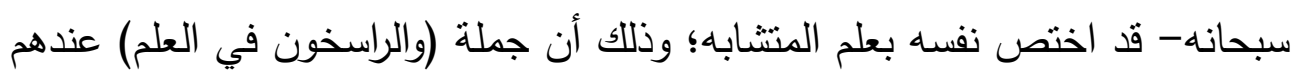

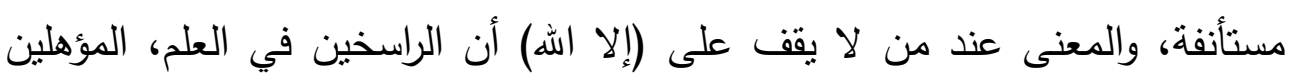

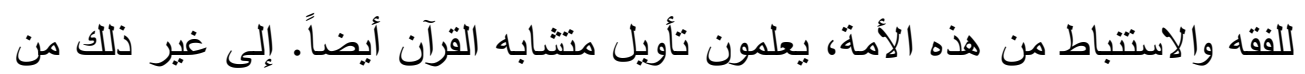

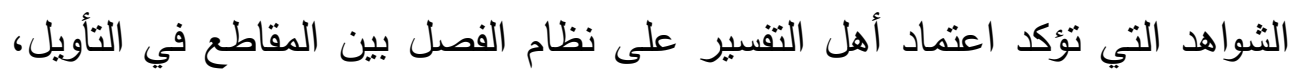

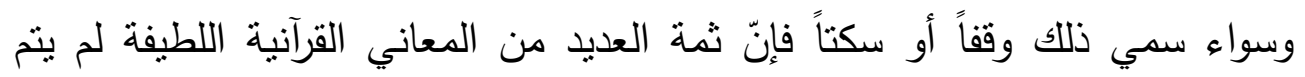

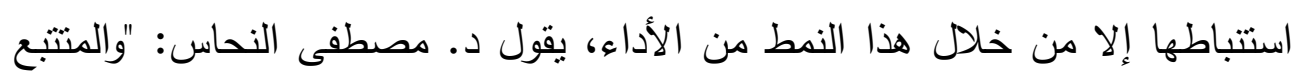

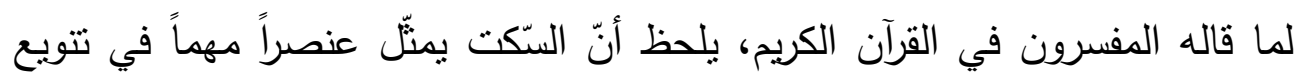

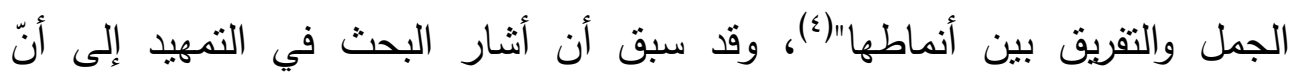

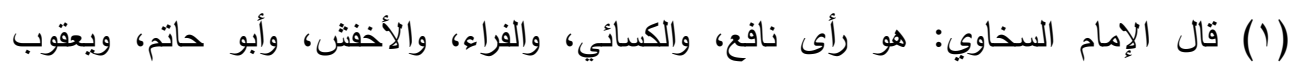

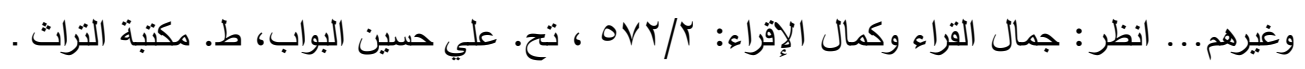

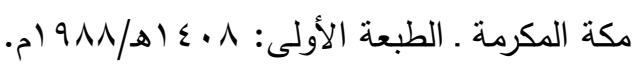
(ז) سورة البقرة: الآية r.

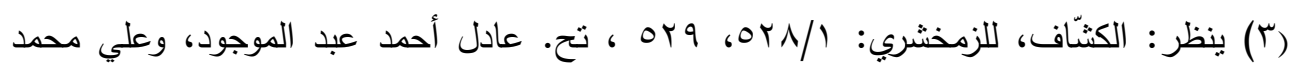

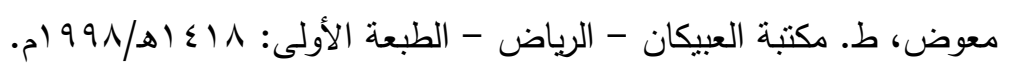
(ع) من قضايا اللغة: عـا ا. 
(السكت) عند د. النحاس نوع من الوقف بمفهومه العام، لا بمفهومه الاصطلاحي في

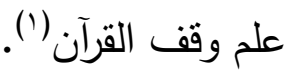

والحقيقة أنّ الدراسات البلاغية لو كانت قد ارتكزت على الخطاب المنطوق بقدر ارتكازها على النصّ المقروء في إدراك الأثر البلاغي، لكان نتاجها أكثر إسهاماً في تحقيق الوظيفة التواصلية للغة العربية، ولعلّ البلاغيين معذورون في ذلك بأنّ الدرس الصوتي العربي لم يساعدهم كثيراً في تأسيس نظريات صوتية منكاملة يمكن الانطلاق منها نحو درس بياني لساني، يُنظّر للأداء البليغ ويوجهه، وهذا يؤكد على ضرورة التحاقل والتكامل بين فروع الدرس اللغوي العربي؛ لأنّ "الدرس اللغوي لا يُفهم جزؤه دون وعي كامل بكل أبعاد هذا الدرس، ومن هنا حُق له وهو في نطاق صرفي أن يجعل الصوت هادياً له، وحق له في نطاق النحو أن يوجّه قيم الأصوات نوجيهاً مفسراً، وحق لله أنْ يستخدم المعطيات السابقة كلها في سبيل فهم لفرع من فروع القول، هو فرع البلاغة العربي"(؟). السّكت وتشكيل المعاني النحوية: إذا كانت المعاني تتشكل في الذهن أولاً، ثم تظهر في صورة لفظية عند النطق بها، فإنّه ينبغي أن تتطابق الصورة اللفظية المنطوقة للمعاني مع صورتها في الذهن، وهنا يظهر دور الأداء بالسّكت ليسهم في بلورة معاني النحو وتشكيلها في الخطاب المنطوق. ولا يستبعد بعض الباحثين(ّ) أنْ يكون السّكت والوقف من حيث انتماؤهما إلى علوم القرآن، يمثلان الأساس الذي استقى منه عبد القاهر الجرجاني وغيره فكرة

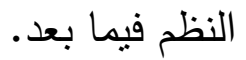

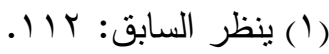

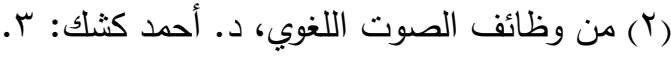

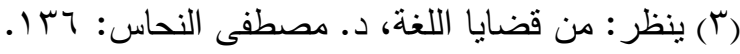


ولا شك في أنّ النحو هو الركيزة الأساسية التي ترتكز عليها المعاني في تشكيلها وبلورتها، و "من وظائف النحو الرئيسة -إن لم تكن هذه وظيفته الرئيسة- أن يعيّن لنا

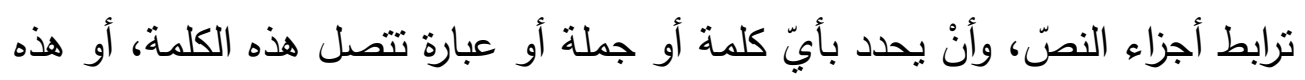

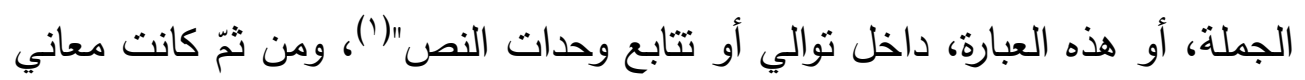

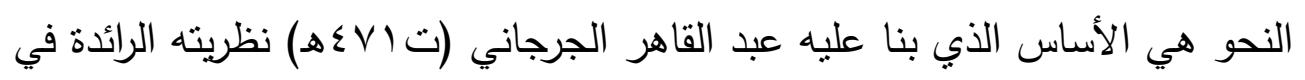

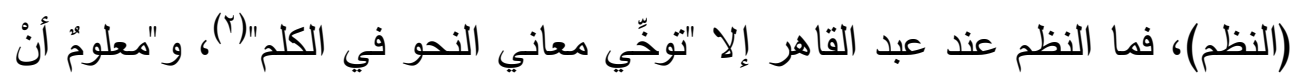

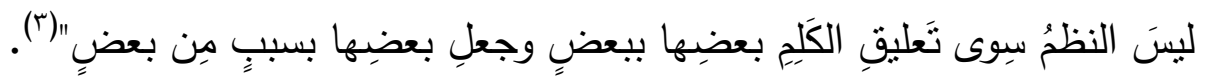

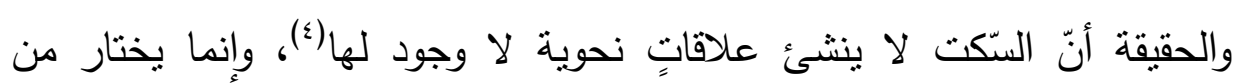

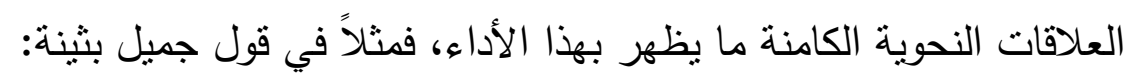

لا، لا، أبوح بحبِ بَتْنَة إنتّها

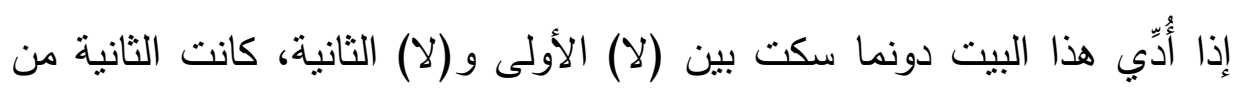

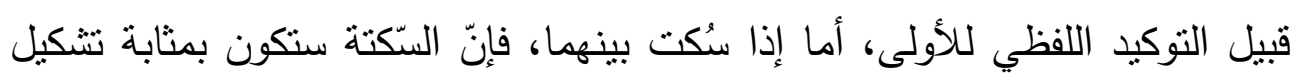

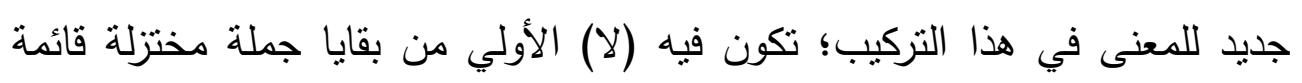

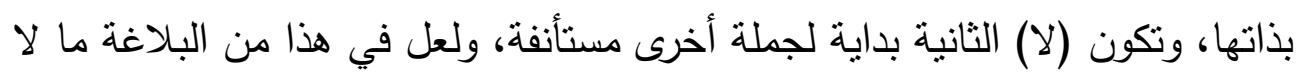

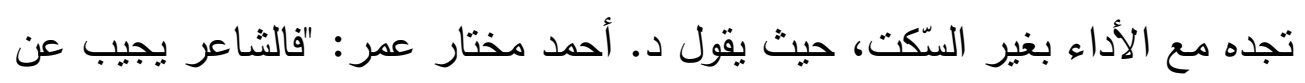
سؤال وارد أساسه: هل تبوح بحب بثنة؟ فكان جوابه: لا، ثم سكت وبدأ في إعطاء

$$
\begin{aligned}
& \text { (1) الإبهام في شعر الحداثة، د. عبد الرحمن محمد القعود: rآץ. }
\end{aligned}
$$

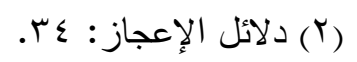

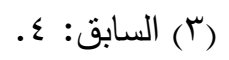

$$
\begin{aligned}
& \text { (ع) ينظر : من وظائف الصوت اللغوي، د. أحمد مختار عمر : .A. }
\end{aligned}
$$

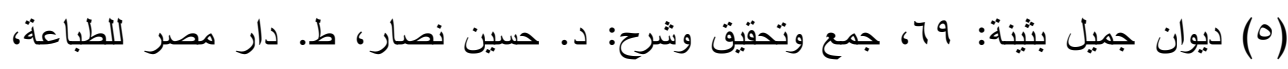

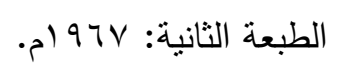


تقرير جيد مؤدّاه: لا أبوح بحب بثنة، إنها أخذت علىّ مواثقاً وعهوداً. الستّت هنا

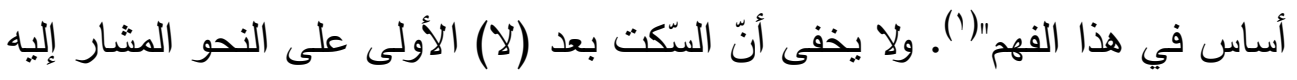
هو أدخل في البلاغة، وأولى بالبيان.

وهناك مسائل نحوية كثيرة يمثّل (الستكت) فيها عاملاً مهماً من عوامل فهمها،

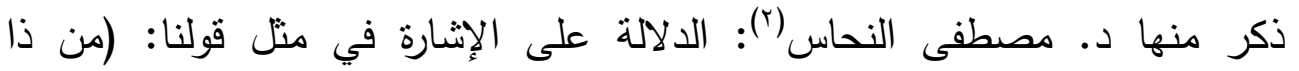

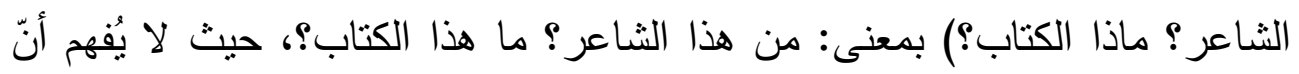
(ذا) اسم إثارة في المثالين إلا إذا سكت المتكلم سكتة خفيفة بعد اسم الاستفهام

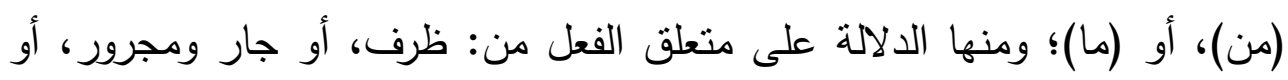

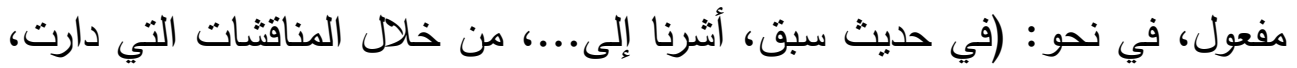

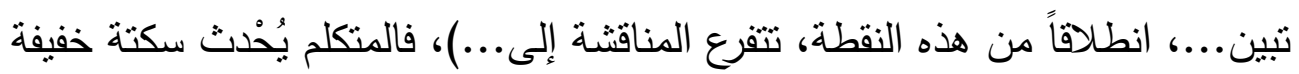

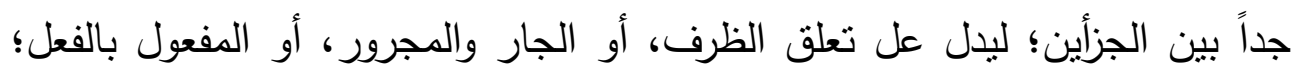

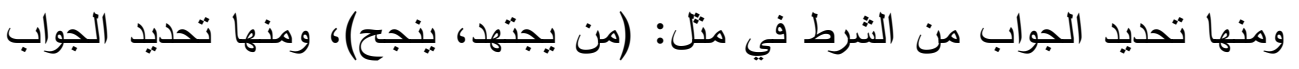
بعد الطلب في مثل: (آتتي، آتك)، ويظهر دور النّكت جلياً في التراكيب التي تقوم

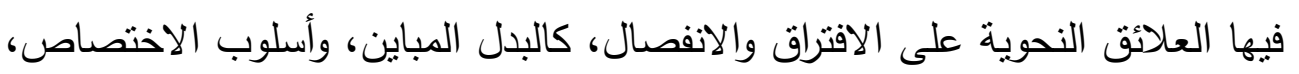
والنعت المقطوع.

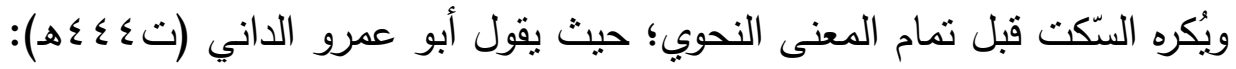

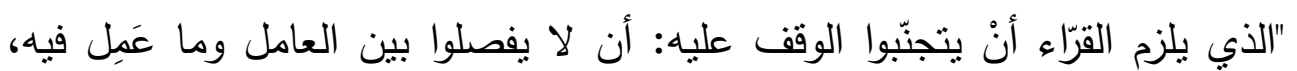

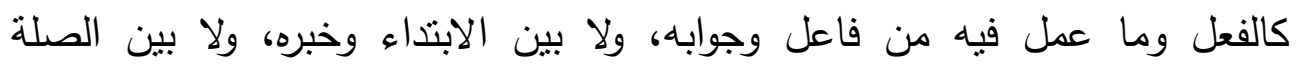
والموصول، ولا بين الوصف والموصوف، ولا بين البدل والمبدل منه، ولا بين 
المعطوف والمعطوف عليه، ولا يقطع على المؤكد دون التوكيد، ولا على المضاف دون المضاف إليه، ولا على شيء من حروف المعاني دون ما بعدها"('). والسّكت قبل تمام المعنى المتصل في بعض الأحيان لا يشكّل بياناً، ولا يحقق إفهاماً، بل إنّه قد يودِي بالبيان، ويُوَّدِّي إلي اللبس في موطن الإفهام، وقد عاب النبي

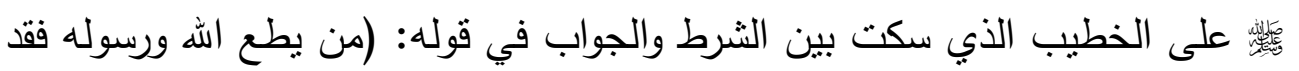

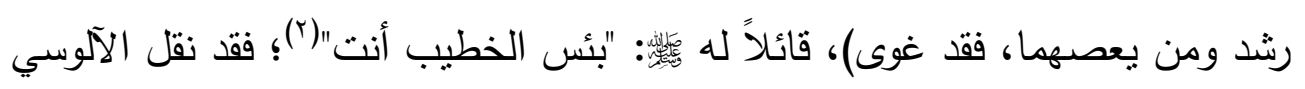

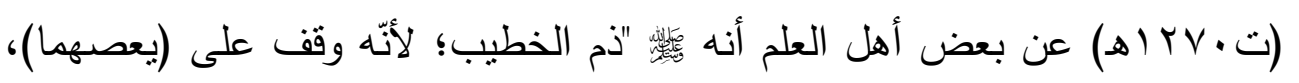
وسكت سكتة"(")، وبهذا الأداء يلتبس المعنى، ويتساوى من يطع الله ورسوله مع من الهن يعص الله ورسوله في الرشد، قال أبو جعفر الطحاوي (ت ابrاهـ): "وإنما كان ينبغي له أن يقول: ومن يعصهما فقد غوى، أو يقف عند قوله: فقد رشد، ثم يبتدئ بقوله:

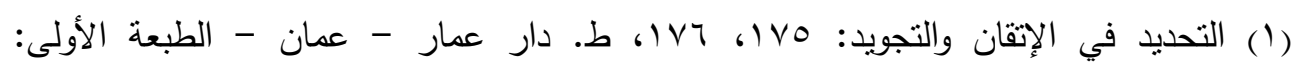
.

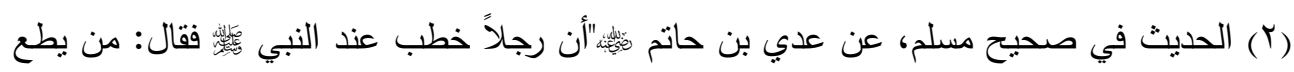
الله ورسوله فقد رشد ومن بعصهما فقد غوى، فقال رسول الله

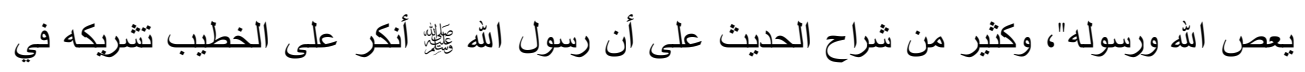

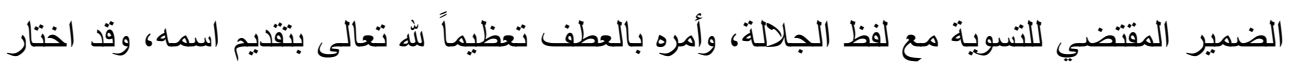

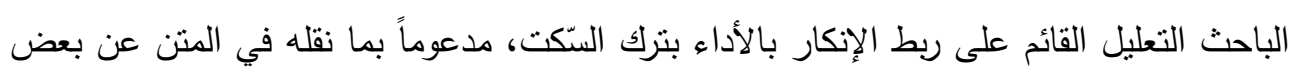

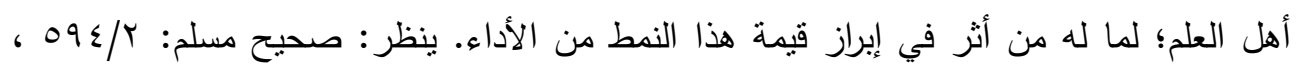

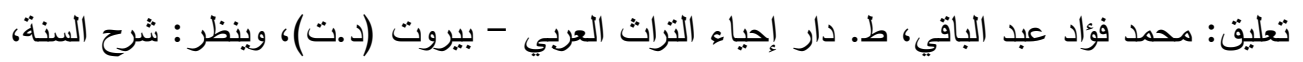

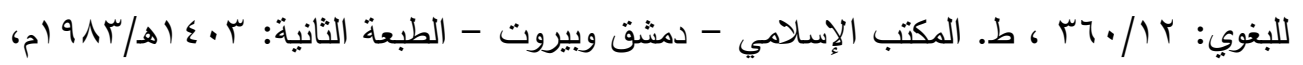
والمنهاج شرح صحيح مسلم بن الحجاج، للنووي: 19/10، ط. دار إحياء التراث العربي - بيروت

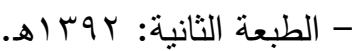

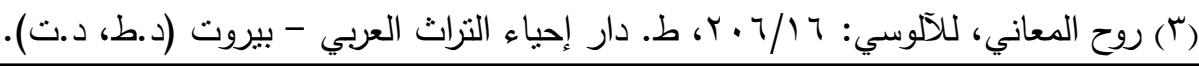


ومن يعصهما فقد غوى...، وإذا كان ذلك مكروهاً في الخطب، وفي الكلام الذي يكلم

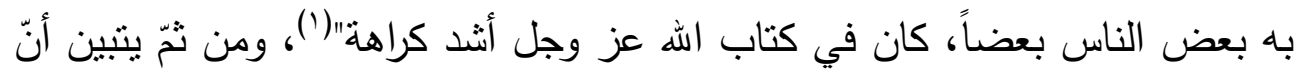
السّكت المطلوب هو السّكت الدفضي إلى حسن البيان، عندما تتداخل المعاني وتختلط الدلالات، أما الستّت في غير موضعه قبل اكتمال المعاني المتلاحمة، فإنه النه قد يفضي إلى سوء الفهم وعدم البيان. دور السّكت في القر اعة الجهرية وفن الإلقاء: لا يختلف اثنان من المشتخلين بالدرس اللغوي في تقدير الدور الحيوي للقراءة الجهرية وفن الإلقاء في العملية البيانية والاتصالية، فمن خلادل إتقان هاتين المهارتين،

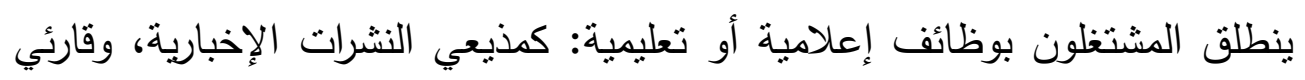

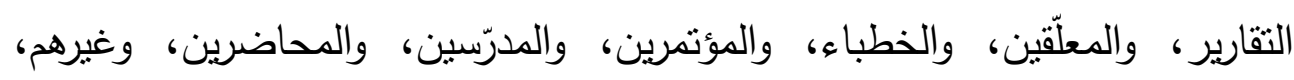

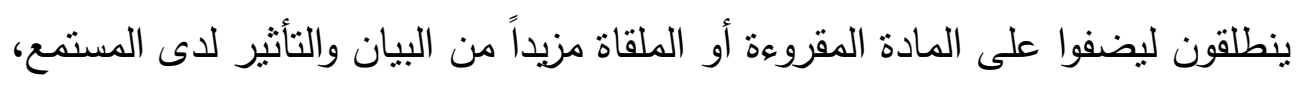

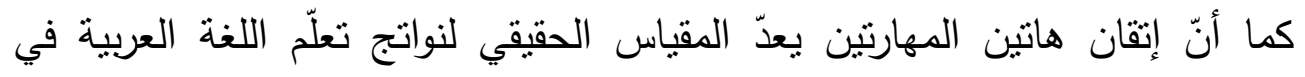

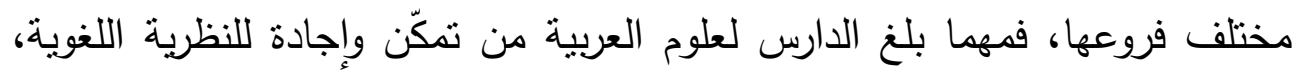

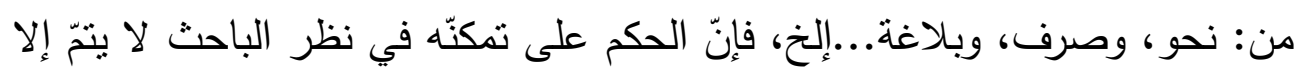

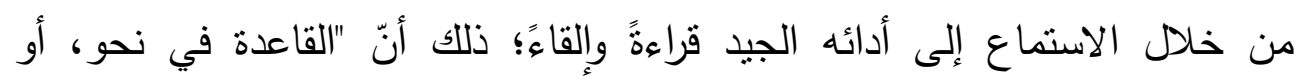

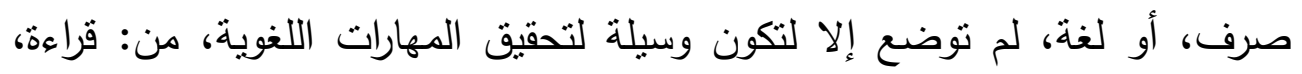

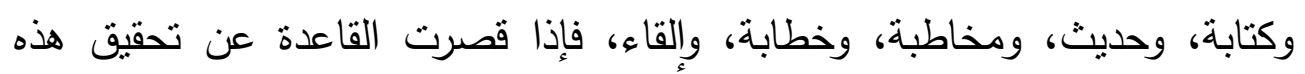

(1) بيان مشكل الآثار ، للطحاوي: / / || ، ، تح. شعيب الأرنؤوط، ط. دار النشر - بيروت (د.ط،

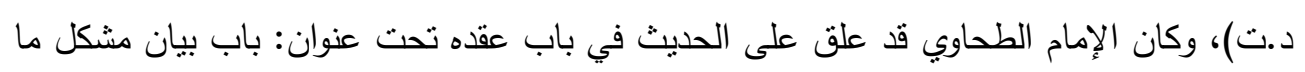

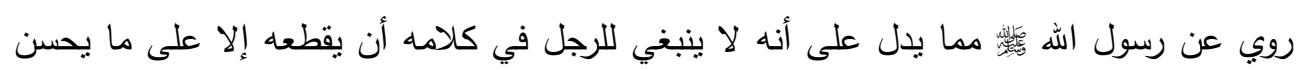
قطعه عليه، ولا يحول به معناه عما تكلم به من أجله. 
المهارات، فلا طائل من تعلّمها إلا حشو الذهن بما لا يفيد، وشغل النفس بما لا

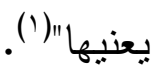
وإذا كانت القراءة الجهرية تعني: "الإدراك البصري للرموز الدكتوبة، والإدراك

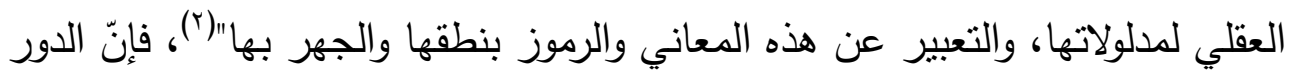

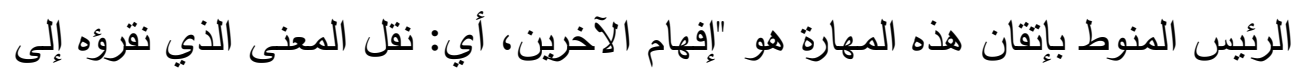

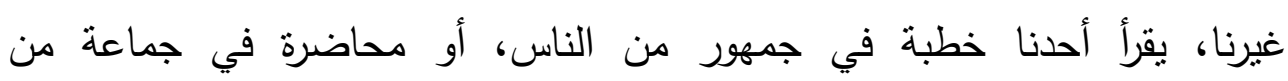

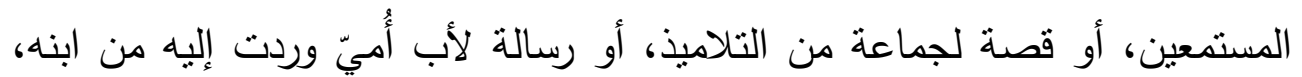

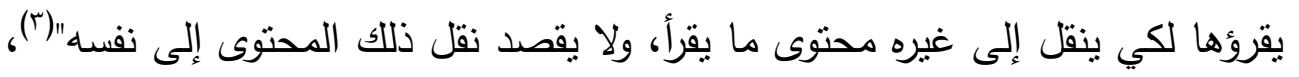

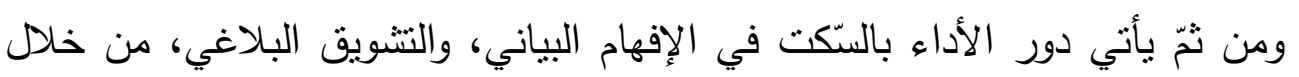

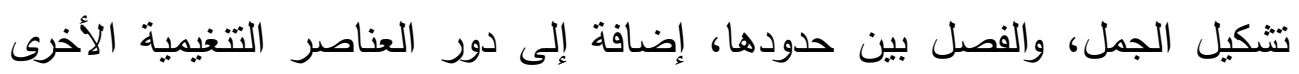

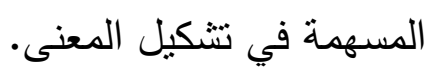

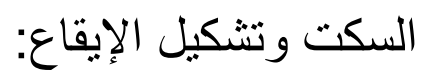

من خلال القراءة الجيدة وحسن الإلقاء يتشكل الإيقاع في الخطاب المنطوق، ومما

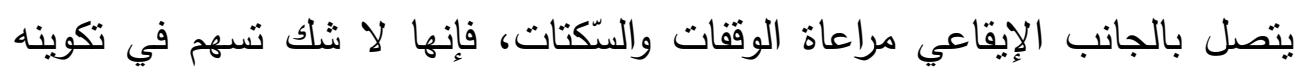
والإحساس به، والإيقاع هو : "التوازن الناشئ عن ثقارب الثباعه بين المسافات الفاصلة

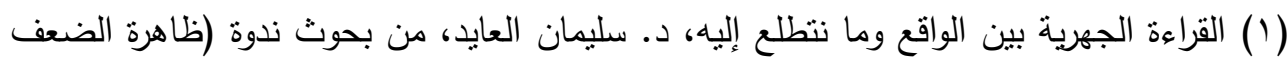

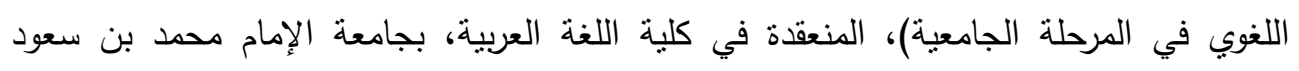

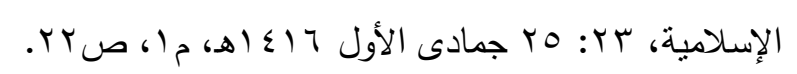

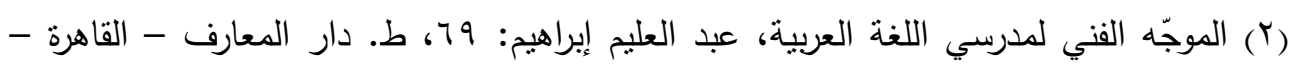

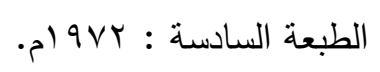
(ז) نحو نعليم اللغة العربية وظيفياً، داود عبده: 9 ج ، ط. مؤسسة دار العلوم - الكويت - الطبعة

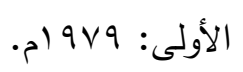




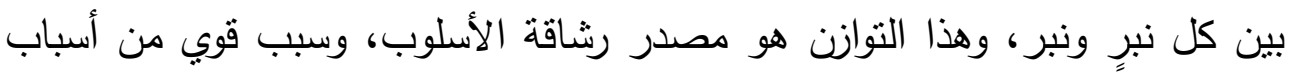

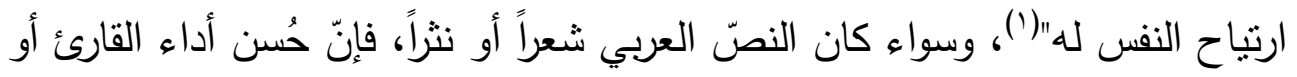

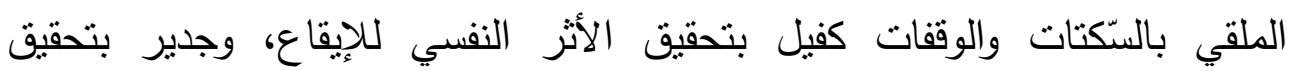

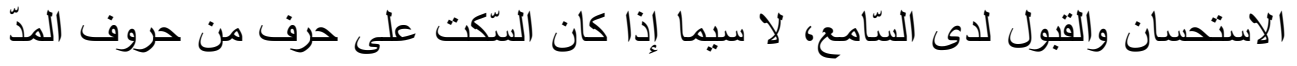

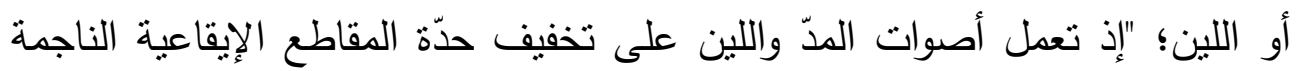

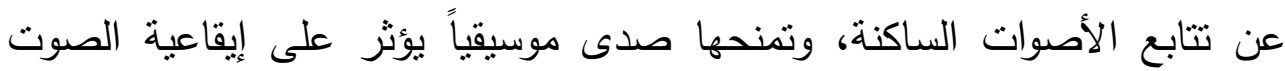

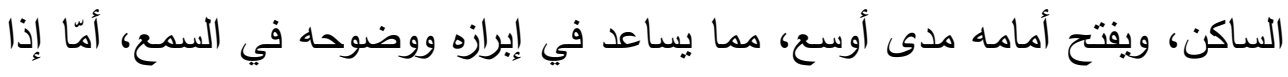

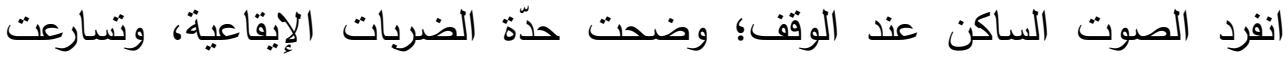

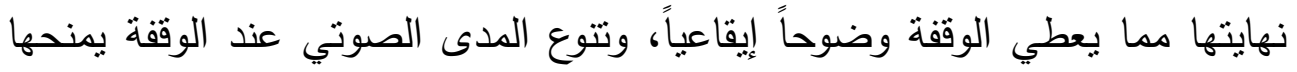

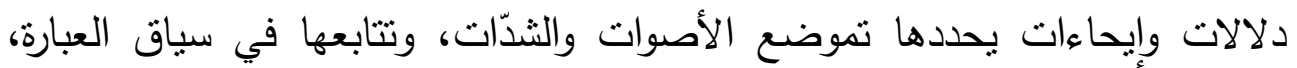
ومن هنا يمكن القول: إنّ الوقف على أصوات اللين يمنح السياق الإيقاعي تأثيراً

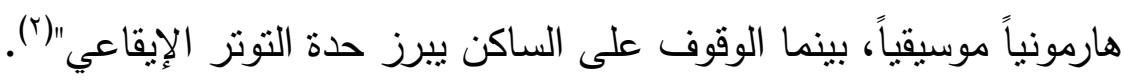
كما يمتّل الأداء بالستّت عنصراً فاعلاً في إبراز شعرية (البياض) في إلقاء

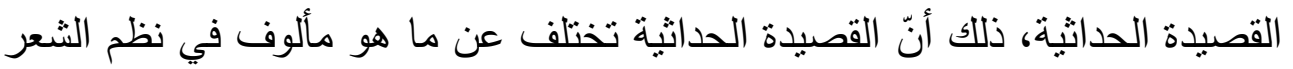
العربي الموروث حتى في طريقة رسمها وكتابتها، ففي شعر الحداثة يتعمّد الثتعراء

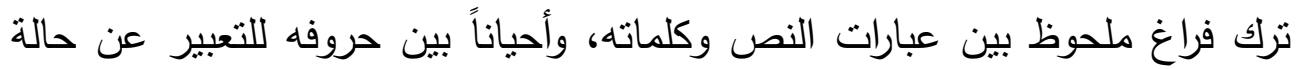
من الستكت أو الصمت، ولكل صوت مكان يبدأ منه، حسب توزيع السواد والبياض

(1) الفاصلة القرآنية بين المبنى والمعنى، د. عبد محمد شبايك: •، ط. دار حراء - القاهرة -

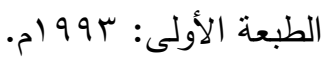

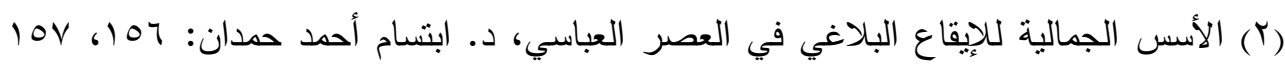

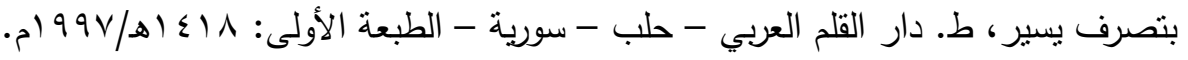


داخل الصفحة(')، ويعد (البياض) في التجربة الشعربة المعاصرة وسيلة من وسائل توفير الإيحاء وتوصيل الدلالة للقارئ(؟)، ولا بدّ لقارئ هذا النوع من القصائد أو ملقيه أنْ يسكت سكتاً يطول أو يقصر في مواضع البياض، على حسب المساحة البيضاء المتروكة بين النصّ والنصّ الآخر • كيف يكون الأداء بالسكت؟

أمّا عن كيفية الأداء بالسيّت فإنه يتتوع بحسب اكتمال المعاني وعدم اكتمالها، حيث ذكر بعض الباحثين (r) أنّ السكتَ نوعان: أحدهما، السّكتة عند النهاية الكاملة، وتندى (السّكتة القاطعة)، والنهاية الكاملة هي الوصول إلى المعنى القاطع التام الذي لئ يصلح لأن يكون ختاماً للموضوع كله، وتسمى السّكتة بالقاطعة لأنها تقطع الكلام في نهايته الطبيعية التي لا يشعر السامع أو المتحدث عندها بالحاجة إلى كلام جديد، والصوت عند هذه السّكتة يهبط إلى القرار الذي يشعر بالانتهاء، وتستعمل النقطة (.) من علامات الترقيم للالالة عليه. والنوع الثاني من السيّتات: السّكتة عند النهاية الناقصة، وهذا النوع من الأهمية بمكان في مجال القراءة الجهرية وفن الإلقاء؛ لأن المتكلم حرّ في تقطيع جمله بسكتات يتخيّر مواقعها، ويحرص على أن تكون مساعدة على إظهار ما يريده من المعاني، وعلى أن تكون أداة فعالة في التأثير على السامعين، والصوت عند هذه

(1) الثعرية العربية الحديثة، شربل داغر: جr، ط. دار نوبقال للنشر - المغرب - الطبعة الأولى: . $) 9 \wedge 1$ (r) ظاهرة الثعر المعاصر في المغرب، محمد بنيس: . . 1، ط. دار التتوير للنشر - بيروت .01910

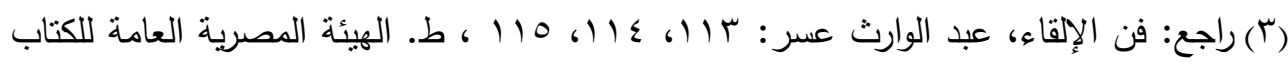

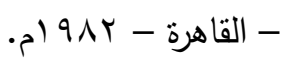


السّكتات ينقطع مائلاً صاعداً إلى منطقة الحنجرة، أو منطقة الرأس أحياناً في حالات:

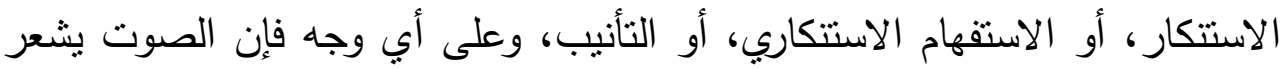

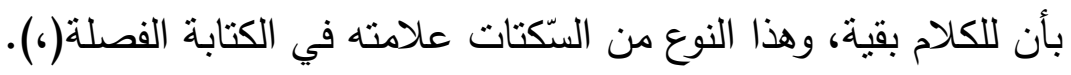
والمهم في أداء هذه الستكتات أنه برافقها تتغيم خاص يناسب مقتضى الحال من

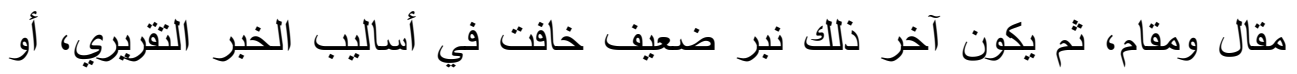

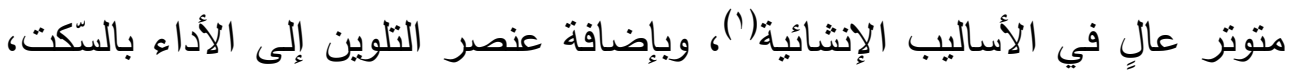

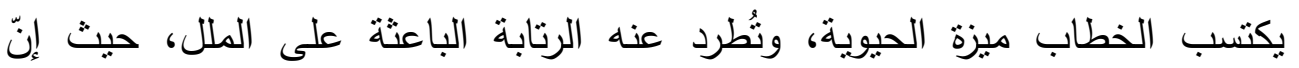
"مراعاة التلوين الصوتي بما يقتضيه المعنى، يجعل لكل سكتة نغمة مغايرة لما قبلها

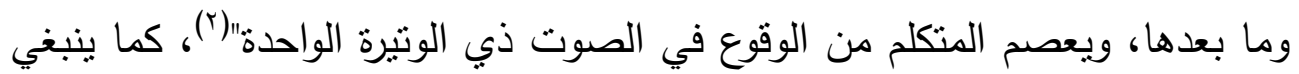

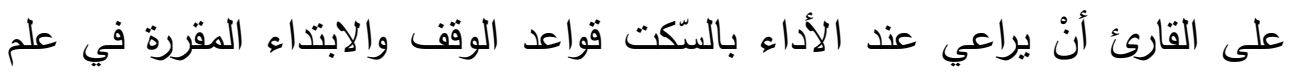
الصرف والتجويد، من: الوقف على الساكن، والوقف على المنون رفعاً وجراً، وإبدال

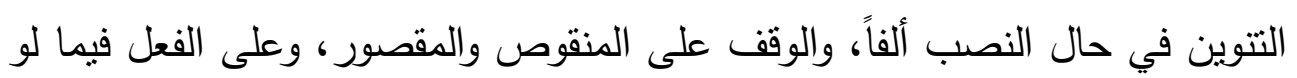
بقي على حرف واحد، ومراعاة قواعد النطق بهمزة الوصل عند الابتداء بها...إلخ. والأصل في الوقف والنيّكت ألا يُفصل بين العامل والمعمول كما تقدّم، لكن ذلك

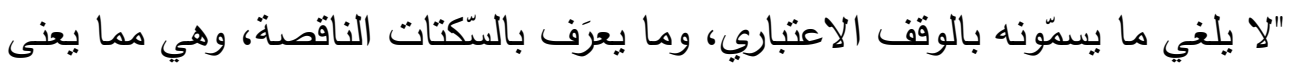

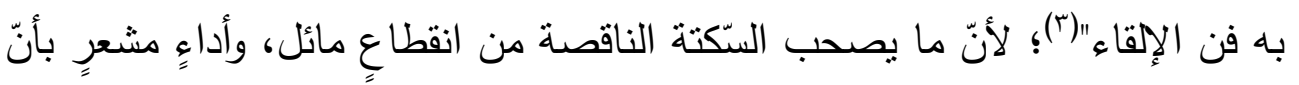

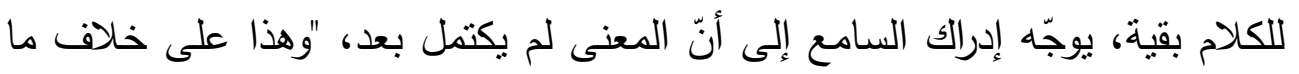

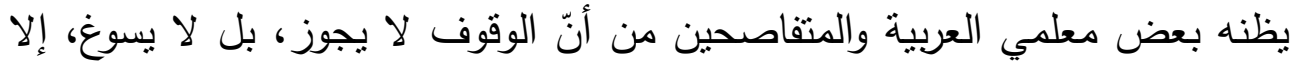

(1) ينظر : علامات الترقيم في اللغة العربية، د. فخر الدين قباوة: عا، ط. دار الملنقى للطباعة

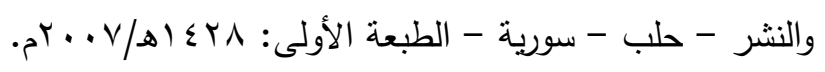

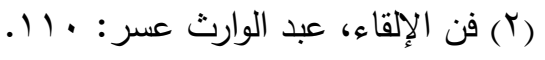

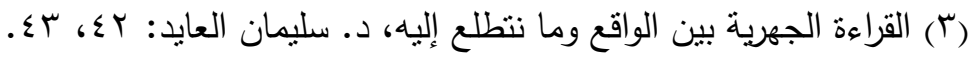


إذا كان على تمام المعنى، فتجده يقراً بَفَس واحد، سطراً أو سطرين، أو ثناثنة فأكثر؛ لأن المعنى في زعمه لم يتم، فلا يجوز الوقوف قبل تمامه!"(1)، وطالما لم يكن السّكت موهماً خلاف المقصود من الكلام، أو مؤدياً إلى لبس أو غموض، فإنّ للقارئ أن لن

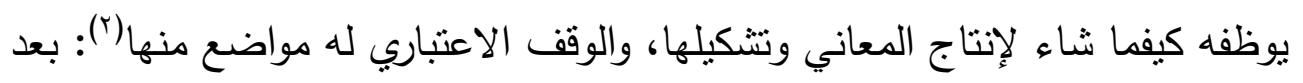
المنادى، وبعد القسم، وبعد القول، وقبل الجمل الاعتراضية أو التفسيرية وبعدها، وعند إرادة زيادة البيان أو التوكيد، أو التأثير في السادعين.

ويوجّه بعض المعنيين بفن الإلقاء إلى توظيف الأداء الأمنل بالسّكت، حيث يقول د. طارق سويدان: "لا تتوقف عن الحديث في وسط الجملة فهذا يضعف من أهميتها، لا تجعل وقفاتلك بالطول نفسه؛ فالانتقال إلى موضوع رئيس يتطلب وقفة أطول من الانتقال إلى نقطة فرعية، لا تتردد في استعمال الوقفات (السّكتات)...، لا تطل الوقفات"(؟)، والحقيقة أنّ مهارة الأداء بالسّكت والوقف وغيره من أنماط الأداء، لا لاءله تكتسب إلا بطول التدرب والمران، وبكثرة الاستماع للنماذج الأدائية الجيدة. علامة السكت في النص المكتوب: وينوب عن السّكت كما يدل عليه في النص المكتوب الواو المقلوبة (،)، وتسمى:

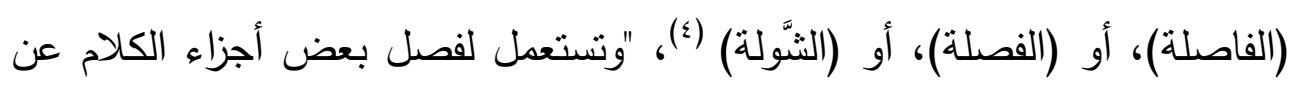

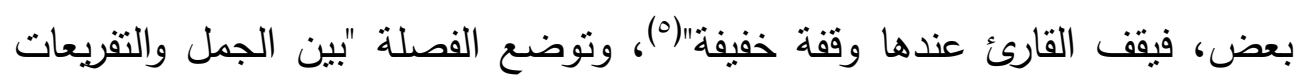

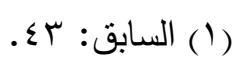

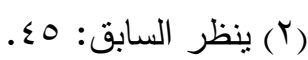
(r) فن الإلقاء الرائع، د.طارق سويدان: 19 19، ط.شركة الإبداع الفكري- الكويت- الطبعة الأولى: . $r$ r.

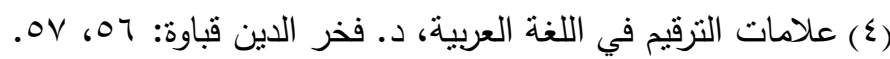
. 9 V V (0) 
المتعاطفة، والتراكيب الطويلة في الجمل الدديدة، وبين المنادى وجواب النداء، والقسم وجوابه، من الثعر والنثر، ولا يجوز أن تقع بين المتلازمين، كالفعل والفاعل، والمبتدأ

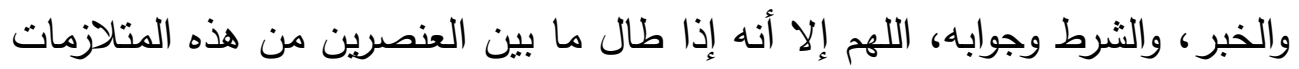
في التعبير، وجبت إذ ذاك فاصلتان تميزان ما هو مطوَّل؛ ليعود اتصالها في التعبير

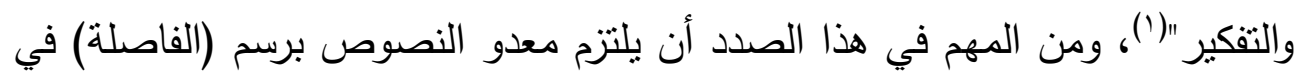

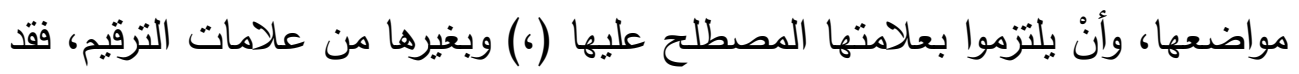
رأينا لدى بعض من كتب في السّكت أنهم بستبدلون بعلامة الفاصلة (،) علاماتٍ

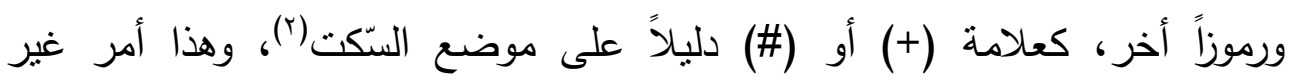
مستحب، لأنّ الرموز المصطلح عليها في علم الترقيم (علامات التزقيم) بمثابة معالم

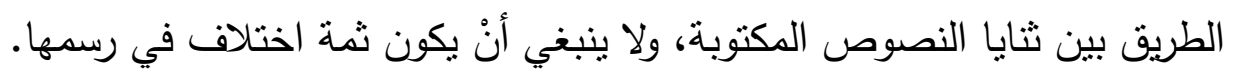

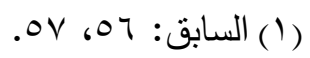

(r) ينظر : دراسة الصوت اللغوي: اسب، وعلم اللغة المبرمج: 109 1، وأبحاث في أصوات العربية: 


$$
\begin{aligned}
& \text { المبحث الثالث } \\
& \text { السّّكت في أداء القرآن الكريم }
\end{aligned}
$$

يمثّل (السّكت) نمطاً خاصاً من أنماط الأداء القرآني لدى بعض القراء؛ فأبو

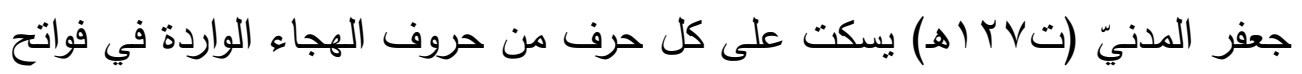

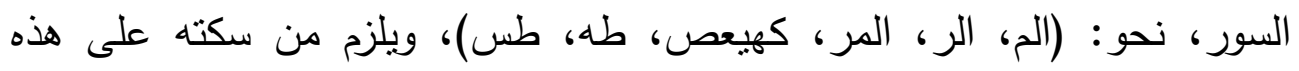

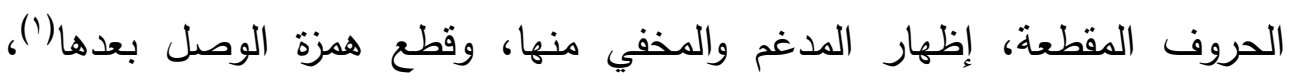

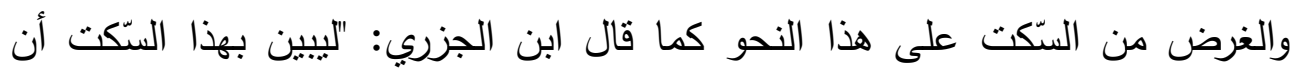

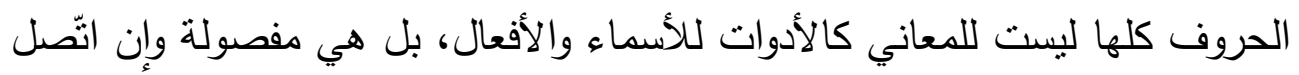

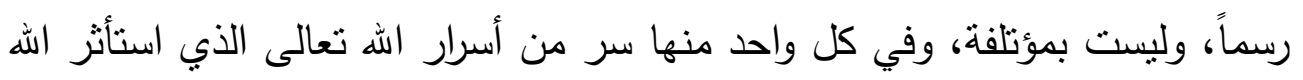

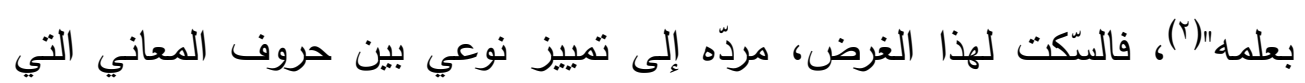

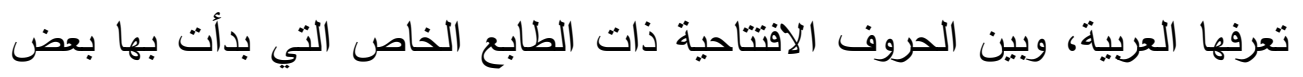

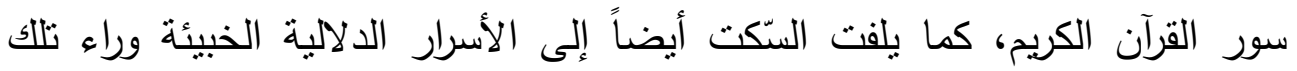

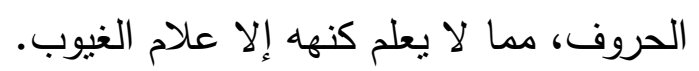

ويسكت حفص بن سليمان (ت.11 (ه) في أربعة مواضع من الذكر الحكيم،

1. على الألف المبدلة من التتوين في (عوجا)، من قوله نعالى في سورة

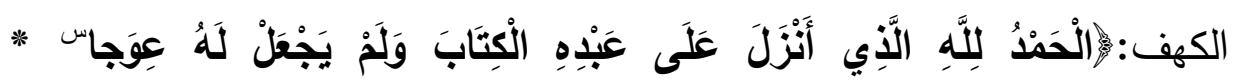

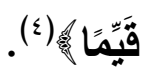

$$
\begin{aligned}
& \text { (1) النشر في القراءات العشر، لابن الجزري: / / (1)ء. } \\
& \text { (r) السابق: نفسه. }
\end{aligned}
$$

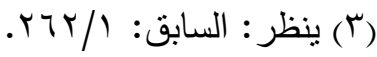




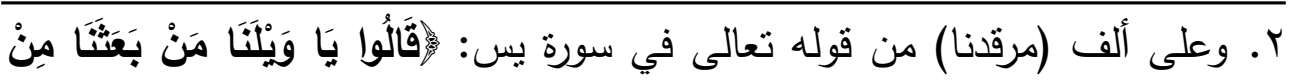

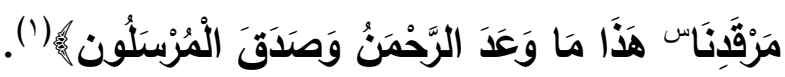

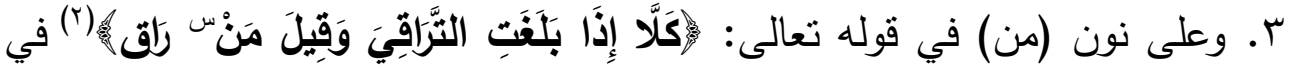
سورة القيامة.

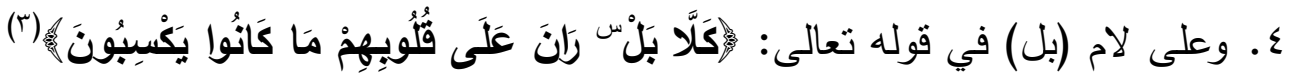
في سورة المطفقين.

ويمكن القول بأنّ الغرض من سكت حفص في هذه المواضع الأربعة من القرآن

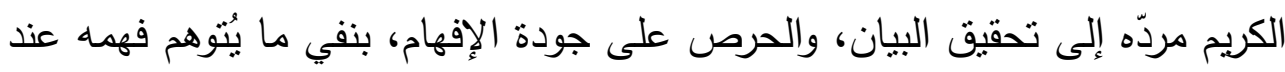

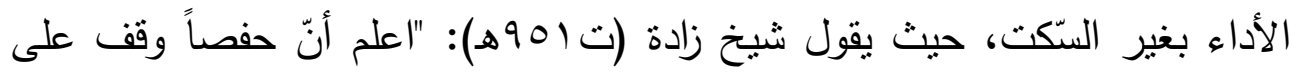

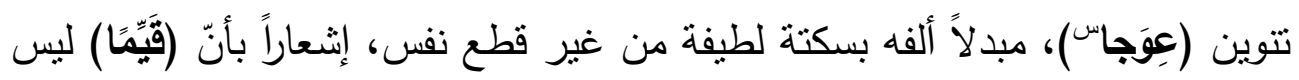

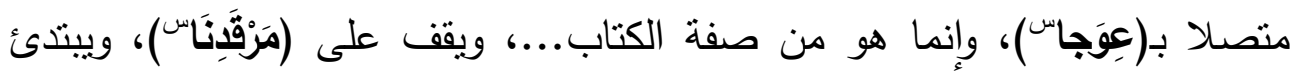

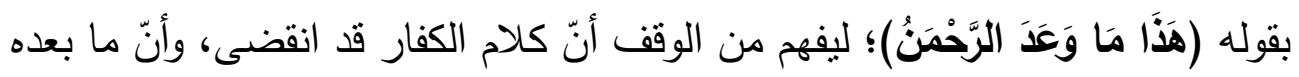

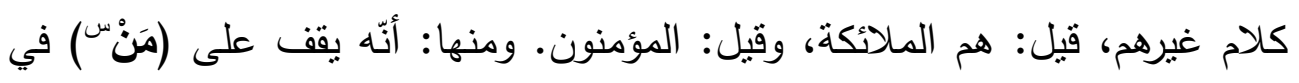

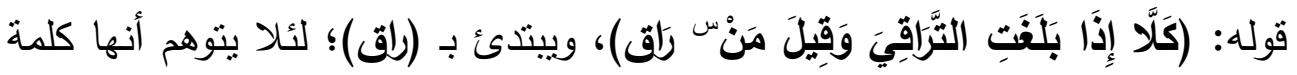

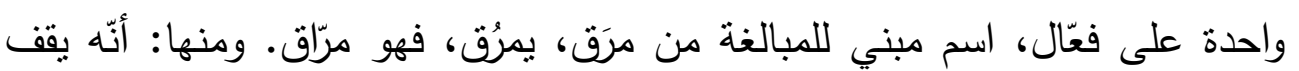

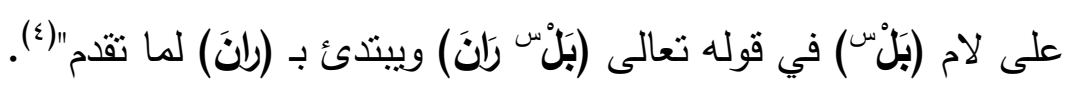

(1) (1) سورة يس: الآية ror.

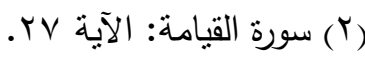

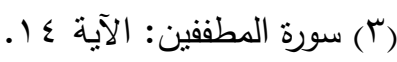

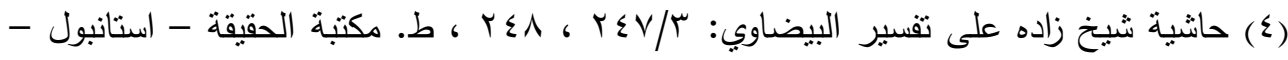

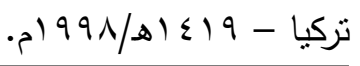


لكن الذي يلفت إليه البحث، أنّ ثمة بعض اللطائف البلاغية التي يمكن تلمّسها من خلال الأداء بالسّكت في هذه المواضع؛ لا سيما إذا عرفنا أنّ السّكت فيها رهين الرواية والنقل والسماع؛ حيث يقول ابن الجزري "الصحيح أنّ السّكت مقبّ بالسماع

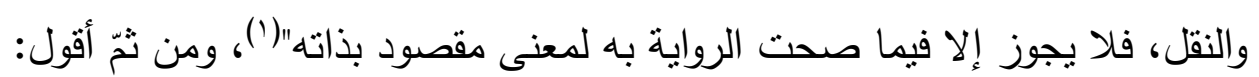
أمّا السّكت على الألف المبدلة من التتوين في (عوجا)، من قوله تعالى في سورة

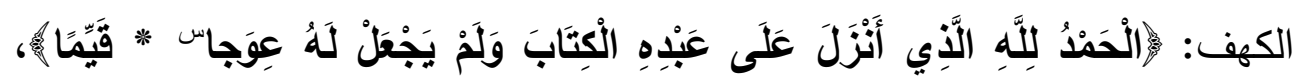
فإنّ فيه من بلاغة التوكيد بالتكربر ما يقطع الطريق على أي مدّع بشكك في استقامة

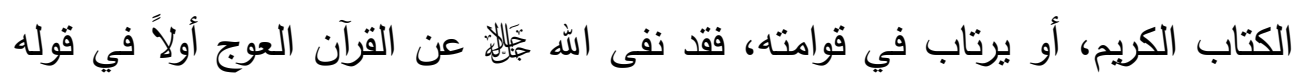

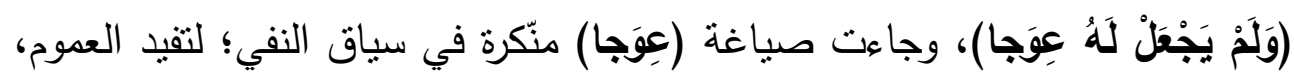

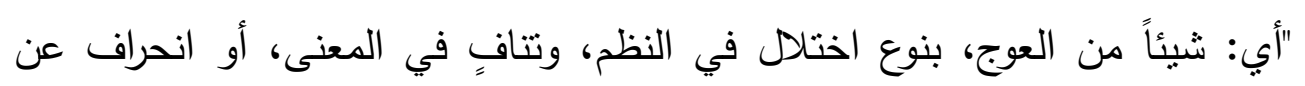

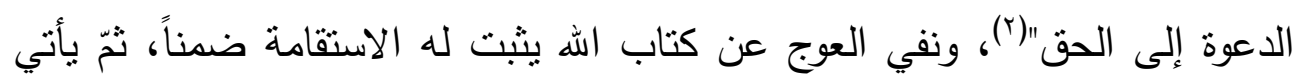
قوله (قَيًِّا) ليثبت الاستقامة للكتاب الكريم صراحة ونصاً، فكأنّ معنى الاستقامة أثنت لأت للقرآن الكريم مكرراً، مرة بالنفي، وأخرى بالإثبات، "وإنما جنح إلى التكرير لفائدة منقطعة النظير، وهي التأكيد والبيان، فرُبّ مستقيم مشهود له بالاستقامة، مجمع على بلى بلإلى استقامته، ومع ذلك فإنّ الفاحص المدقق قد يجد له أدنى عوج، فلما أثبت له وهي الاستقامة أزال شبهة بقاء ذلك الأدنى الذي يدق على النظرة السطحية الأولى"(r)،

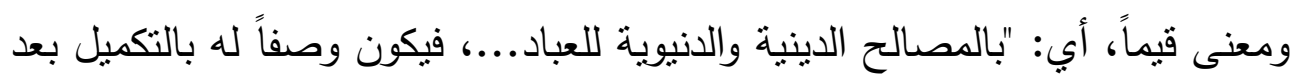

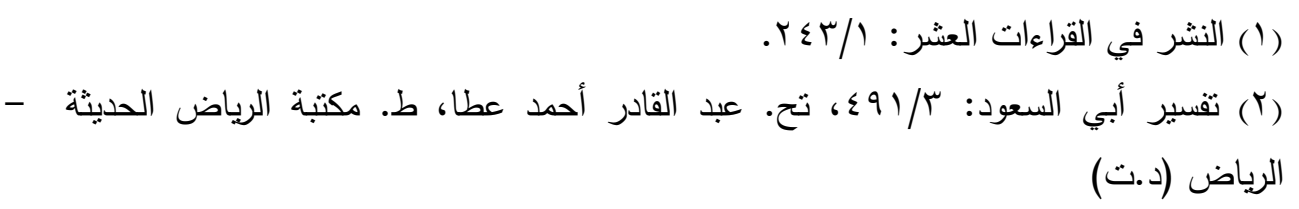

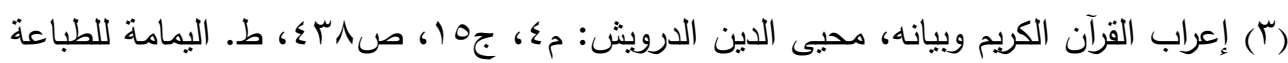

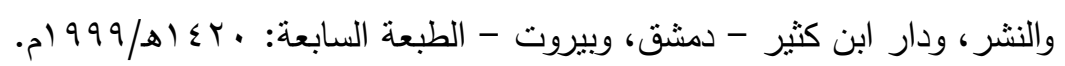


وصفه بالكمال، أو على ما قبله من الكتب السماوية، شاهداً بصحتها، ومهيمناً عليها، أو متتاهياً في الاستقامة"|(1).

وعلى الرغم من أنّ (عِوَجا) رأس آية، والوقوف على رؤوس الآيات في القرآن

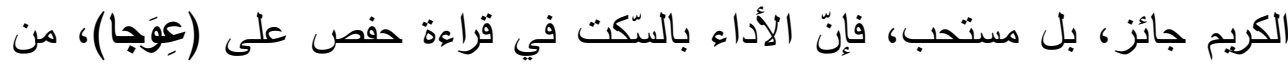

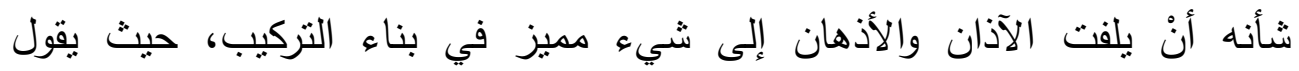

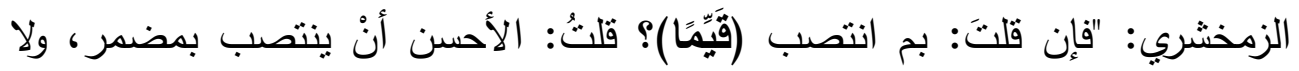

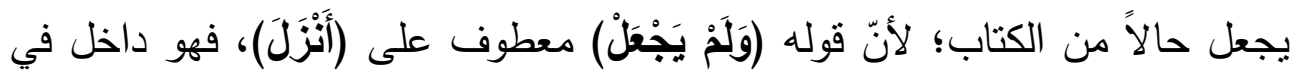

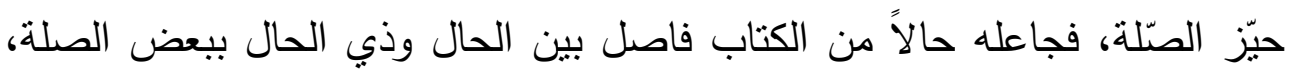

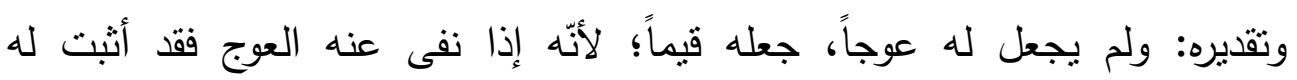

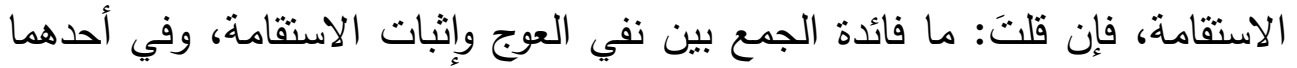

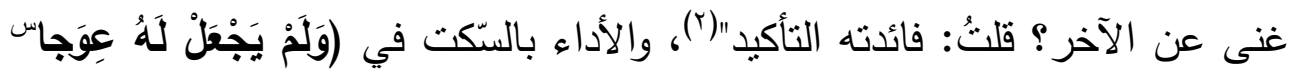

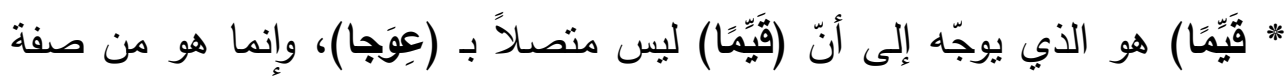
لـ(الْكَتَّبَ).

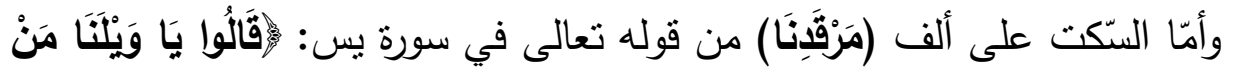

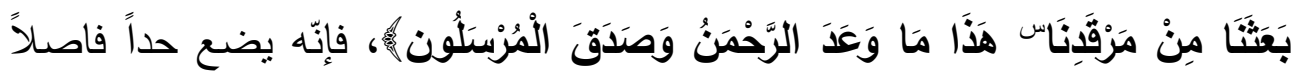

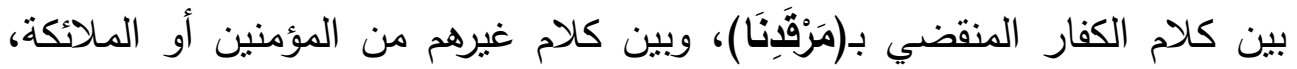

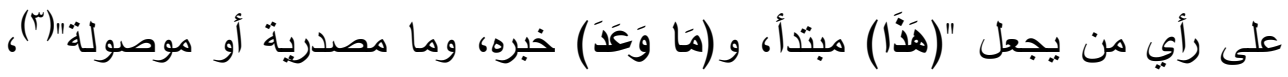

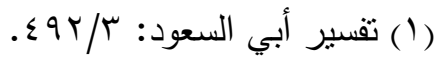

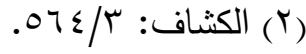

$$
\begin{aligned}
& \text { (r) السابق: Nr/0 ا ـ }
\end{aligned}
$$




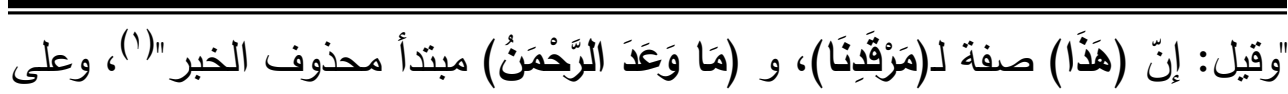

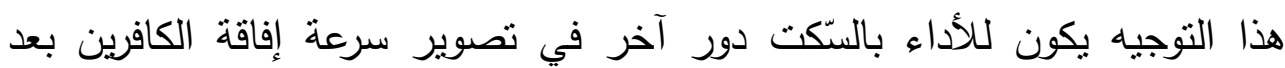

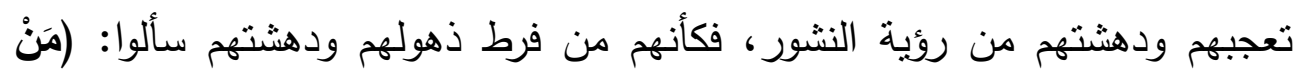

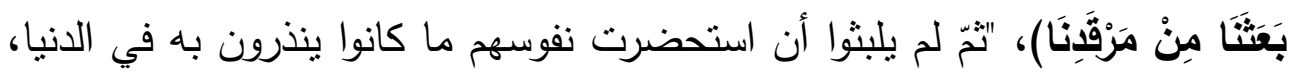

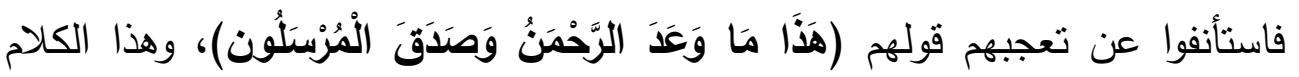

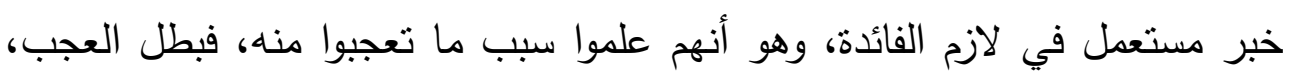

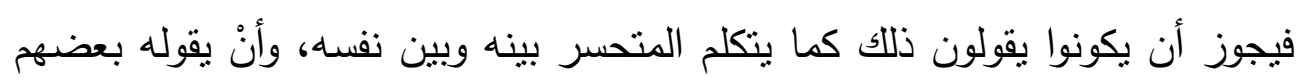

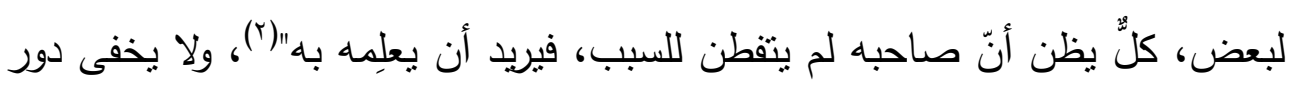

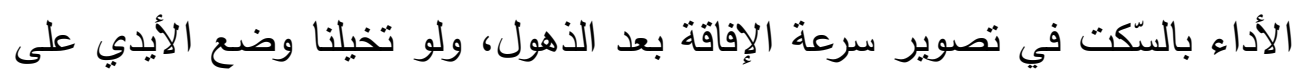

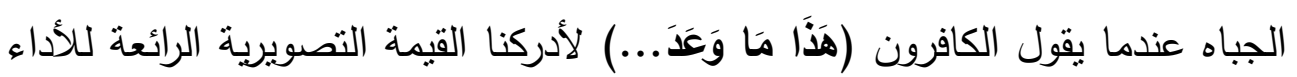
بالسكت في هذا الموضع.

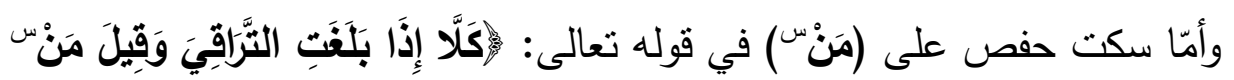

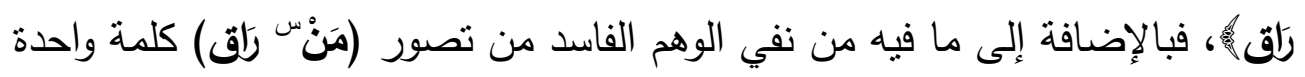

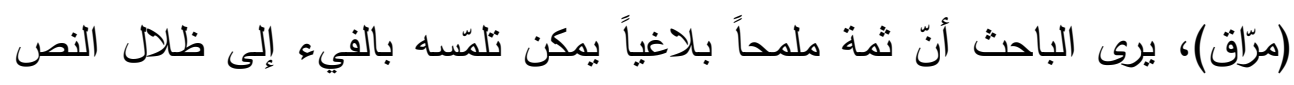

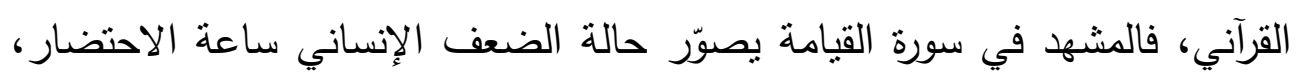

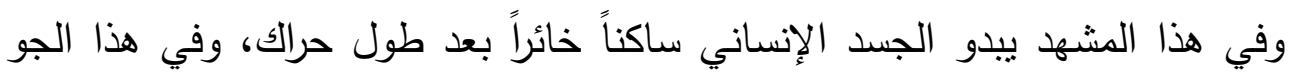

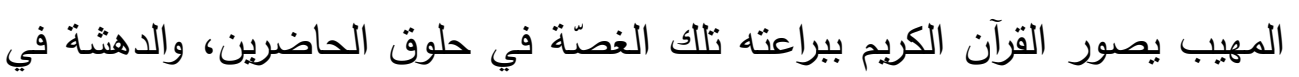

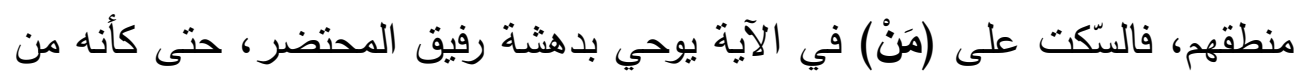

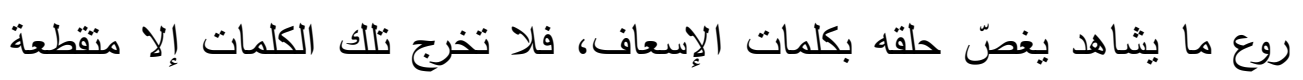

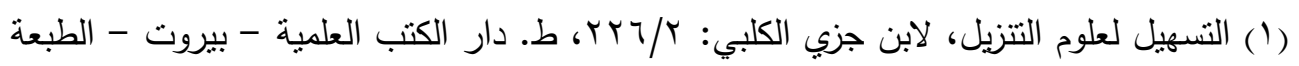

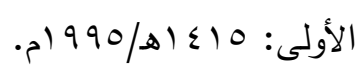

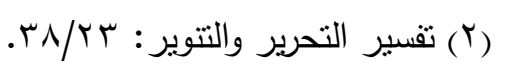


د. على يحي نصر عبدالرحيم

متحشرجة (مَنْس لقا)، والموقف الداعي إلى الذهول لا يحتمل مزيداً من الكلمات

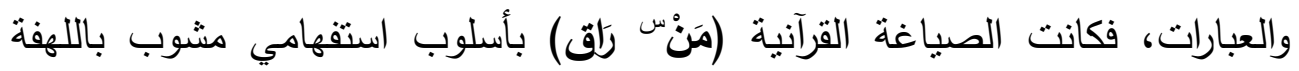

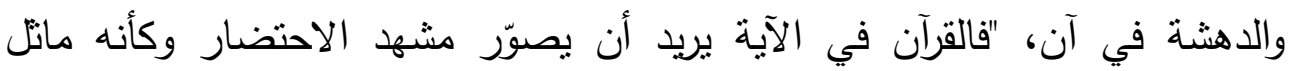

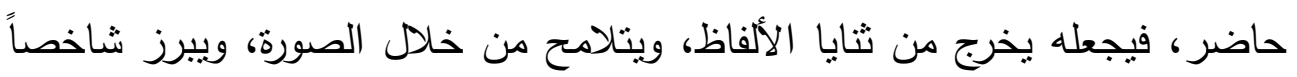

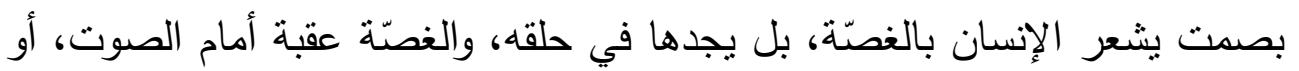

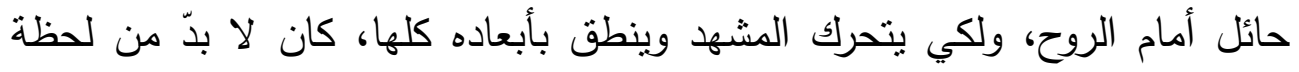

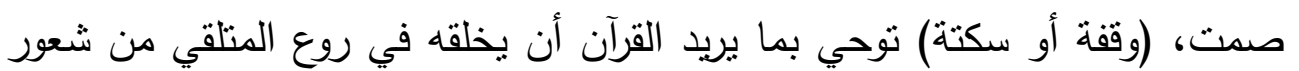

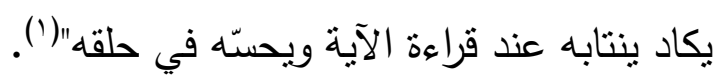

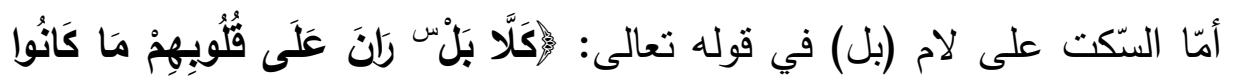

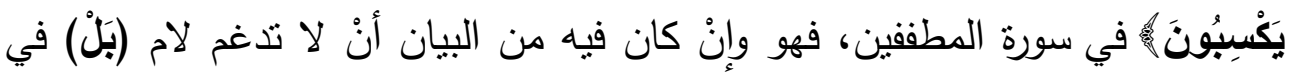

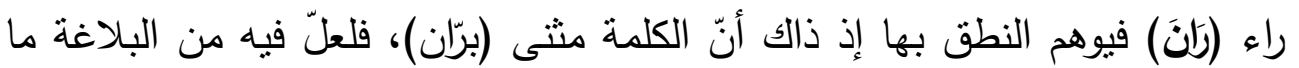

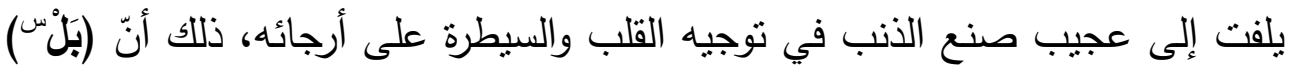

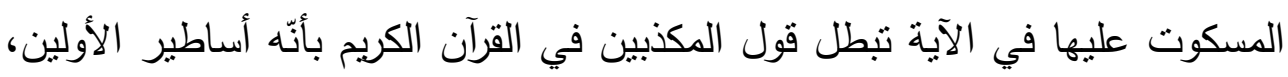

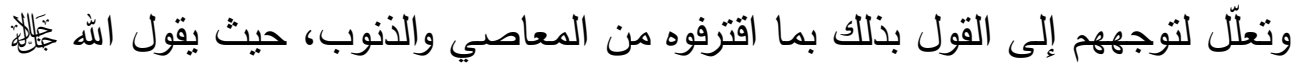

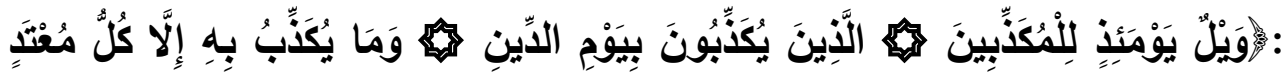

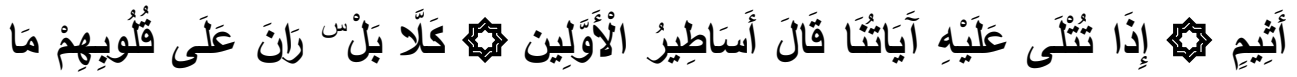

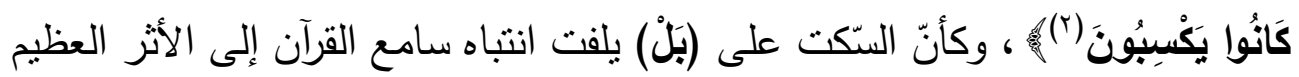

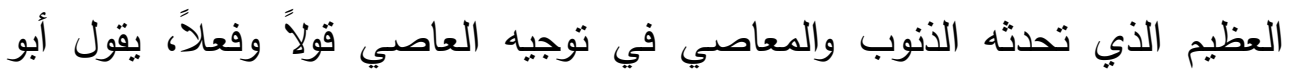

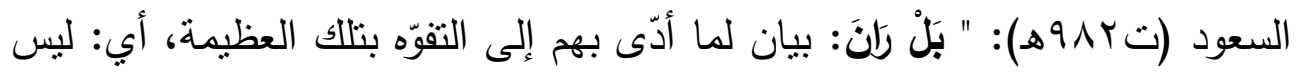

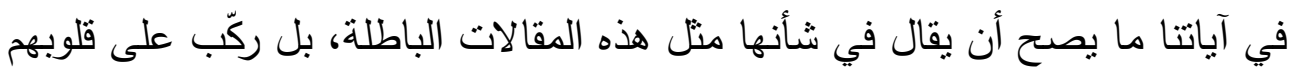


وغلب عليها ما كانوا يكسبون من الكفر والمعاصي، حتى صارت كالصدأ في المرآة،

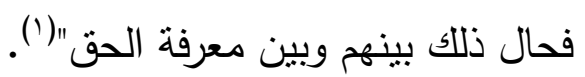
أمّا عن كيفية الأداء بالستكت في الأداء القرآني، فالضابط في ذلك أمران، أحدهما: أنّ السّكت زمنه أقل من زمن الوقف، وهذا أمر تقديري ونسبي، حتى إنّ أئمة الأداء

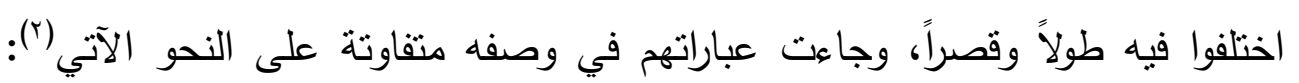

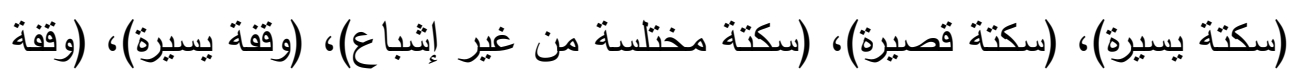
خفيفة)، (وقيفة)، (تسكت حتى يظن أنك قد نسيت ما بعد الحرف)، والثاني: أنّ الأداء

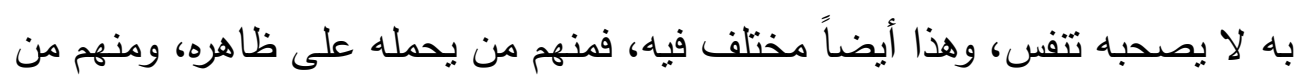

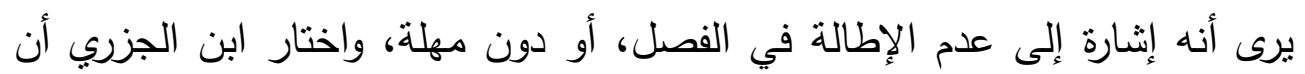

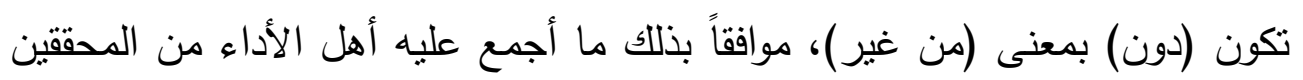

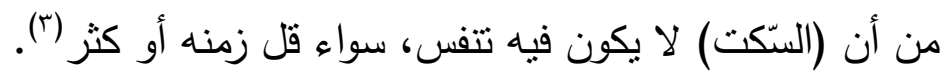

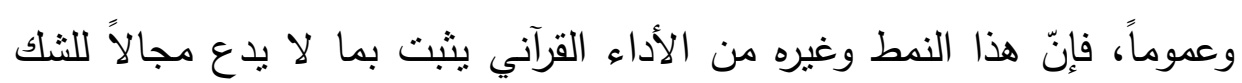

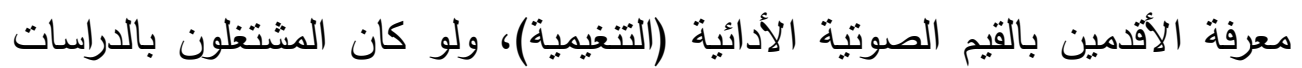

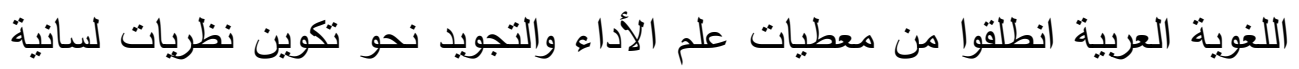
متكاملة، لكان لنا السبق في تأسيس علم لساني عربي خالص، منلما كان لنا السبق لفاء في تأسيس غيره من علوم اللغة.

الخاتمـــــــة

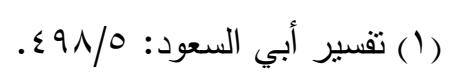

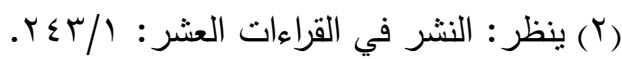

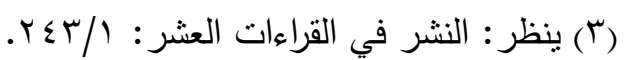


وفي الختام يقدم الباحث ملخصاً لما كان البحث حوله بدندن، قبل صياغة بعض التوصيات المقترحة فيما هو متعلق بموضوعه:

أمّا عن الملخص، فإنّ فكرة الأداء بالسّكت (موضوع الدراسة) تقوم على إبراز حيوية وفاعلية هذا النمط من الأداء في الإفهام والبيان، وفي تشكيل المعاني وبلورتها، وفي فض الاشتباك بين حدود التراكيب المتداخلة، وفي الإدراك البلاغي لبعض التراكيب العربية، وقد تتاول البحث في بدايته المصطلحات الأساسية المرتبطة بفكرته (الأداء، السكت، البيان)؛ بغية تحديد مفاهيمها، وبيان مدى ارتباطها وترابطها، ثمّ كان حديث عن معرفة المحيط اللغوي العربي لهذا النمط من الأداء اصطلاحاً واستخداماً، أثثب فيه البحث من خلال النصوص التراثية أنّ الفصل بين المقاطع الكلامية لله مكانته في نتكيل المعاني العربية وفي بيانها، وإنْ لم يحظ بالنصيب

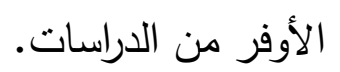

وتناول البحث بعد ذلك دور السكت في العملية البيانية من عدة محاور، حيث أشنار إلى دوره في الإفهام والبيان، وفي مجانبة اللبس والغموض، وفي إدراك وتحقيق الأثز البلاغي لبعض التراكيب المتعاقبة، المبنية على الاستئناف البياني وغيره من أنماط بناء الجمل العربية، وكذا دوره في فهم الجناس التام المركب، فضلاً عن تحقيق أثره البلاغي، ومن جانب آخر أثنار البحث إلى دور السكت في تشكيل وتحديد وفهم المعاني النحوية، مع التببيه على تجنب الأداء به في مواطن اللبس قبل تمام المعنى النحوي، كما تتاول دور الأداء بالسكت في القراءة الجهرية وفن الإلقاء، وفي هذا الجانب كان ثمة حديث عن الوقف الاعتباري، وعن تشكيل الإيقاع من خلال القراءة الصحيحة والإلقاء الجيد، فضلاً عن تحديد المعاني، وتحقيق البيان، كما أثنار البحث إلى ما يدل على السكت في النص المكتوب، من خلال حديث عن الفاصلة (، 
ومواضعها، ثُّ تطرق البحث إلى أنواع السكتات، وما ينبغي مراعاته عند الأداء بها فعلياً.

ويأني الحديث عن السكت في الأداء القرآني ليمثل اللبنة الأخيرة في تمام البناء،

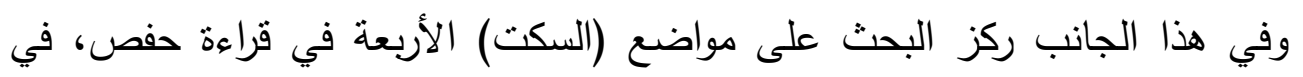
محاولة لاكتشاف بعض اللمحات واللمسات البلاغية من خلال الأداء بالسكت. وأمّا عن التوصيات: فبما أنّ الأداء بالسكت لا بتحقق نفعه إلا من خلال تكامله

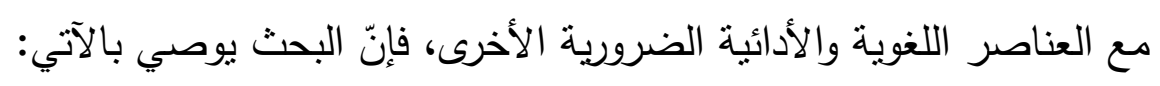
1. الاهتمام بالأداء والتتغيم في تعليم اللغة العربية للناطقين بها وبغيرها على حد سواء، ومن الجيد في هذا الصدد، زيادة عدد الساعات التدريسية والتدرييية للقراءة الجهرية وفن الإلقاء، على أن يكون التدريس والتدريب شاملاً لكافة أنماط الأداء من: وقف، وسكت، وارتقاع، وهبوط، ونبر ، وتلوين، وتزمين، ومخارج...إلخ. r. التركيز على الثمولية في قياس مخرجات تعلُّم اللغة العربية، في كافة المراحل

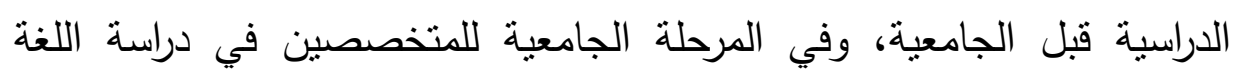

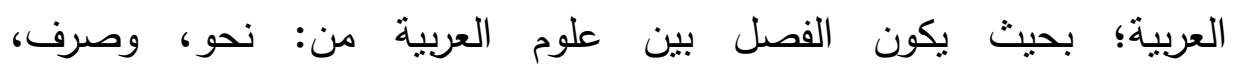

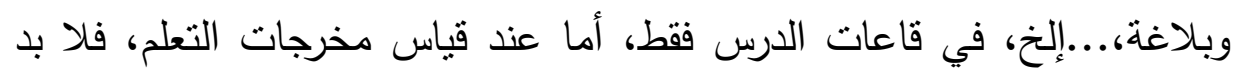
من أن تكون ثمة اختبارات شفهية أدائية شاملة، بالإضافة إلى الماتل الاختبارات

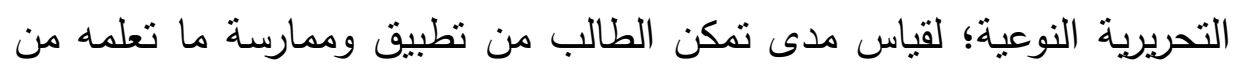
علوم العربية أداءً. r. الاهتمام بالقراءة الجهرية وفن الإلقاء، ليس فقط في مراحل الدراسة الأوّلية، وإنما

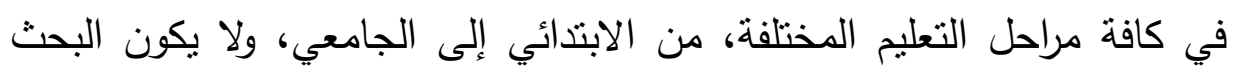
مبالغاً إذا أوصى بضرورة استمرار التدريب على القراءة في مرحلة التأهيل

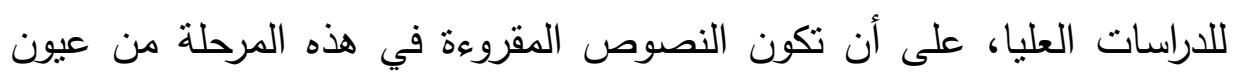


النصوص التراثية، فلكل عصر طرائقه في التركيب والتعبير، ولربما أتقن الطالب قراءة النصّ المعاصر، في حين لا يجيد قراءة النص التراثي ذي الطبيعة التركيبية

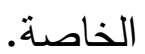

ع. الاهتمام بالتدريب السمعي في تدريس القراءة الجهرية، من خلال تسجيل نماذج أدائية جيدة؛ فالسماع الجيد أب الملكات اللسانية، ويمكن الإفادة من الوسائل

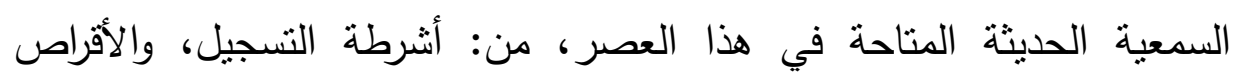

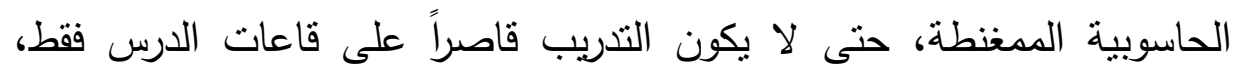
وحتى تأخذ التجربة طابع الاستمرار، وتتخطي حدود الزمان والمكان.

ه. عقد دورات ندريبية مكثفة لتأهيل الشتخلين بوظائف عمادها القراءة الجهرية وفن

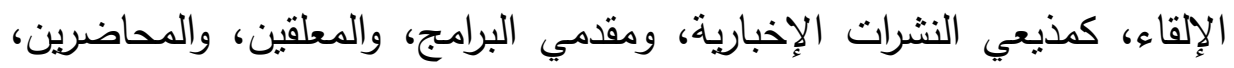

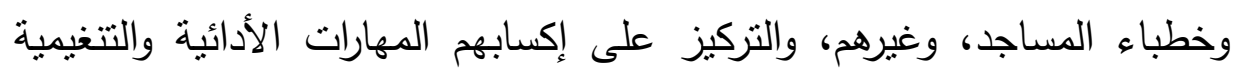

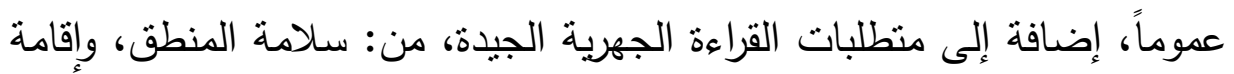
الإعراب، ومراعاة الفصل بين حدود الجمل المتداخلة.... 
1. أبحاث في أصوات العربية، د. حسام سعيد النعيمي، ط. دار الثؤون الثقافية -

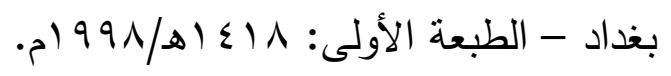

r. الإبهام في شعر الحداثة: العوامل والمظاهر وآليات التأويل، د. عبد الرحمن

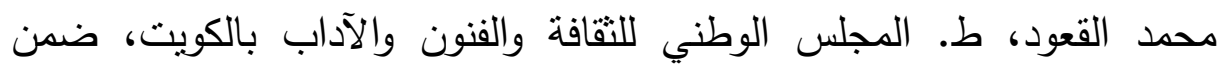

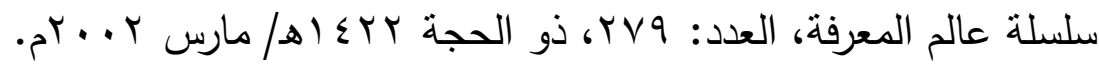
r. الأداء الصوتي في العربية، د.رشاد محمد سالم، منشور في مجلة جامعة الثشارقة

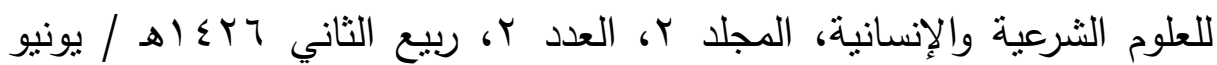
$.5 r+0$

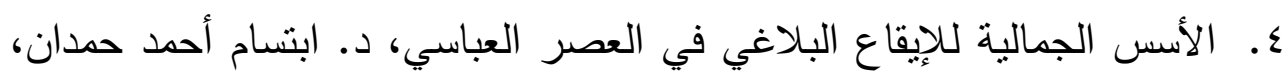

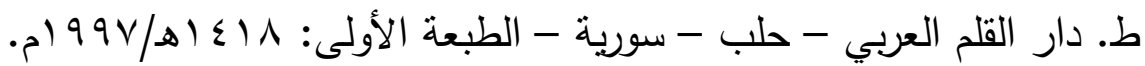
0. أسس علم اللغة، ماريو باي، ترجمة د. أحمد مختار عمر - طرابلس - 9 ام. م. T. الأشباه والنظائر، للسيوطي (عبد الرحمن بن أبي بكر، ت ال (9ه)، تح. إبراهيم

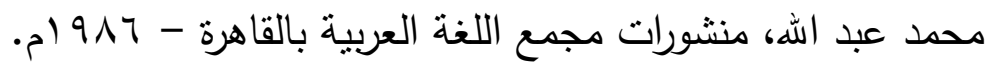
V. أصوات اللغة العربية: دراسة نظرية وتطبيقية، د. محمد حسن جبل، ط. مطبعة

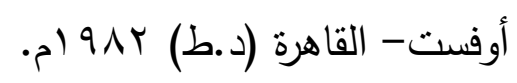

^. إعراب القرآن الكريم وبيانه، محيى الدين الدرويش، ط. اليمامة للطباعة والنشر،

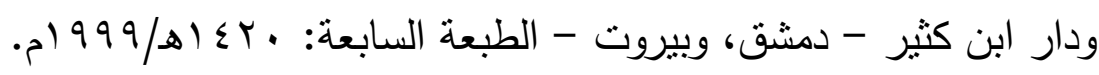


9. الألغاز النحوية، لابن هشام الأنصاري (أبي محمد عبد الله جمال الدين،

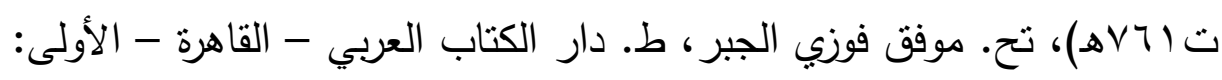

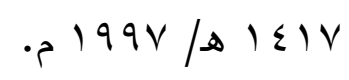

• ا.الإيضاح في علوم البلاغة، للخطيب القزويني (جلال الدين محمد بن القاضي سعد الدين، ت VT V هـ)، ط. دار الكتب العلمية - بيروت - لبنان (د.ت). 11 ا.بغية الإيضاح لنلخيص المفتاح في علوم البلاغة، للثيخ عبد المتعال الصعيدي

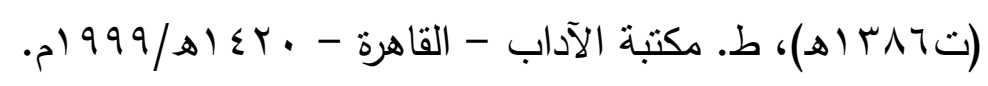

rا. بلاغة الأداء في البيان النبوي، د. محمد علي فرغلي: منشور بمجلة كلية اللغة

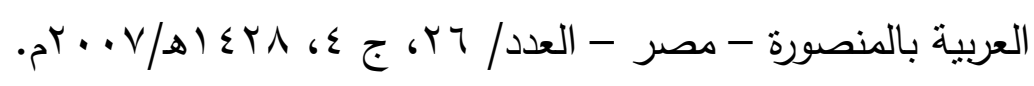
rا.بيان مشكل الآثار، للطداوي (أبي جعفر أحمد بن محمد الأزدي، ت (بrاهـ)،

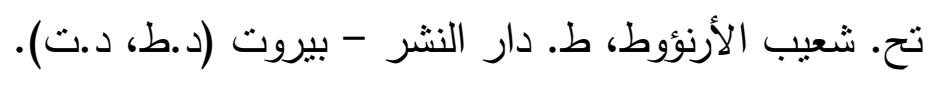

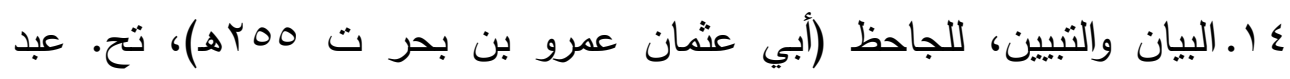
السلام محمد هارون، نشر مكتبة الخانجي - القاهرة- الطبعة السابعة: . $19 \vee \wedge / \infty 1 \leqslant 11$

1. تاج العروس من جواهر القاموس، للزبيدي (محمد مرتضى الحسيني، ت

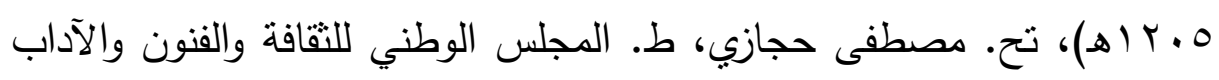

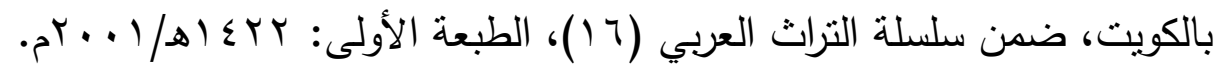
7ا ـ التحديد في الإتقان والتجويد، للاني (أبي عمرو عثمان بن سعيد، ت ع ؟ ؛هـ)

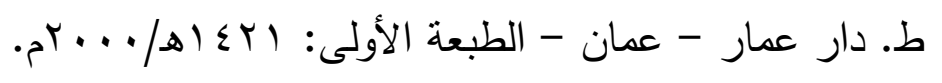

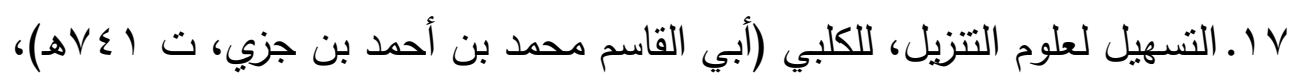

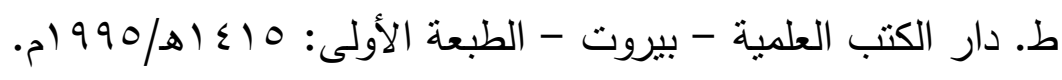


^ا. التطور النحوي للغة العربية، لبرجشتراسر، تح. د. رمضان عبد التواب، ط.

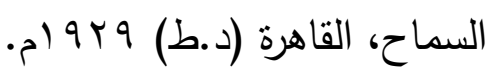

9 ( التعريفات، للجرجاني (علي بن محمد، ت7 (1/هـ)، ط. مكتبة لبنان- بيروت

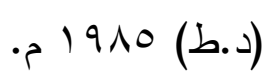

• r.تفسير أبي السعود، المسمى بإرشاد العقل السليم إلى مزايا الكتاب الكريم، لأبي

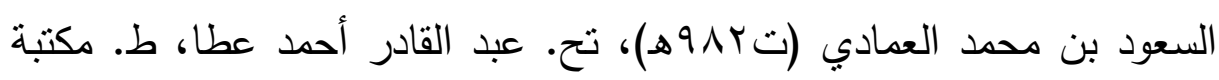

$$
\text { الرياض الحديثة - الرياض (د.ت) }
$$

ا r.تقسير التحرير والتتوير، للأستاذ محمد الطاهر بن عاشور (ت بوس (هـ) ، ط.

$$
\text { الدار النونسية للنشر - تونس- ع } 9 \text { ا } 19 \text { م. }
$$

r r. التتغيم في التراث العربي، د. عليّان الحازمي، منشور في مجلة جامعة أم القرى

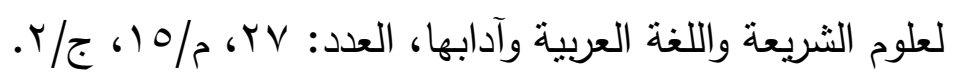

بr.تهذيب اللغة، للأزهري (أبي منصور محمد بن أحمد، ت • Vrهـ)، تح: علي حسن هلالي، مراجعة: محمد علي النجار ، ط.الدار المصرية للتأليف والترجمة

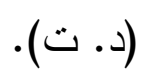

צr.حاشية الدسوقي على شرح السعد، (محمد بن عرفة الدسوقي، ت.بr (هـ)، ضمن شروح التلخيص، ط. مؤسسة دار البيان العربي للطباعة والنشر والتوزيع،

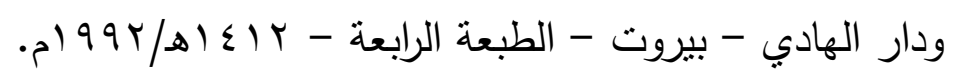

هr.حاشية شيخ زاده على تفسير البيضاوي، (محمد بن مصلح الدين مصطفى القوجوي، ت 901هـ)، ط. مكتبة الحقيقة - استانبول - تركيا (د.ط)

$$
\text { • } 1991 / 81 \leq 19
$$


جr. حاشية يس على شرح التصريح، للثيخ يس بن زين الدين الحمصي، مطبوع بهامش شرح التصريح على التوضيح، للثيخ خالد الأزهري، ط. دار إحياء الكتب إب

$$
\text { العربية (عيسى الحلبي وشركاه) بمصر (د.ت، د.ط). }
$$

VV خصائص التراكيب، د. محمد محمد أبو موسى، نشر مكتبة وهبة، الطبعة

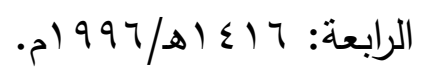

^ץ. الدراسات الصوتية عند العلماء العرب والدرس الصوتي الحديث، د. حسام البهنساوي، نشر زهراء الثروق - القاهرة - الطبعة الأولى: جبـ اهـ/ه . . م.

q. دراسات في فقه اللغة العربية، محمد الأنطاكي، ط. دار الثرق العربي - بيروت - الطبعة الرابعة (د.ت).

• م.دراسات وتطبيقات في علم المعاني، د. يحيى محمد يحيى، ط. الأمانة - القاهرة

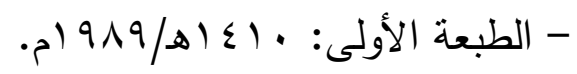

اس.دراسة الصوت اللغوي، د.أحمد مختار عمر، ط. عالم الكتب-القاهرة- الطبعة

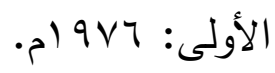

rr.دلائل الإعجاز، للجرجاني (أبى بكر عبد القاهر بن عبد الرحمن بن محمد، ت

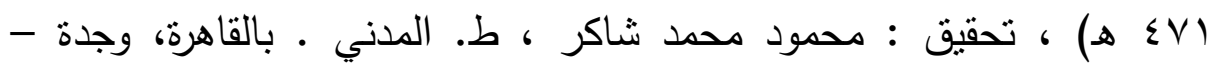

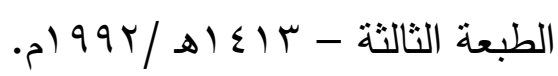

سז.ديوان جميل بثينة، جمع وتحقيق وشرح: د. حسين نصار، ط. دار مصر للطباعة، الطبعة الثانية: 97 امو.

ع ا.روح المعاني في تفسير القرآن العظيم والسبع المثاني، للآلوسي (شهاب الدين السيد محمود، ت. • I Iه)، ط. دار إحياء التراث العربي - بيروت (د.ط، 
هـا.سر الفصاحة، لابن سنان الخفاجي (أبى محمد عبد الله بن محمد بن سعيد، ت

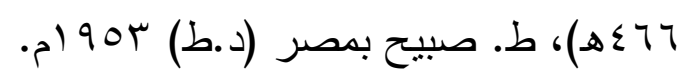

דr.سنن التزمذي، للإمام التزمذي (أبي عيسى محمد بن عيسى، ت بشار عواد معروف، نشر دار الغرب الإسلامي - بيروت (د.ط) 919 ام.

Vس.شرح السنة، للإمام البغوي (أبي محمد الحسين بن مسعود، ت 7 (0)هـ)، تح.

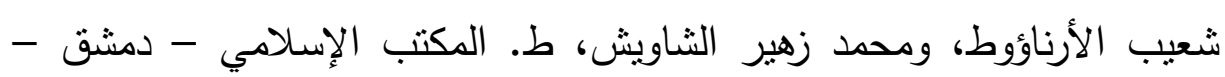

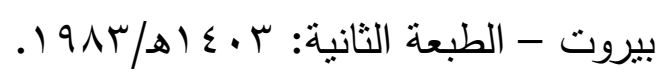

^م.الشعرية العربية الحديثة: تحليل نصي، شربل داغر، ط. دار توبقال للنشر -

$$
\text { المغرب- الطبعة الأولى: } 911 \text { ام. }
$$

و س. الصناعتين: الكتابة والشعر، للعسكري (أبي هلال الحسن بن عبد الله ت

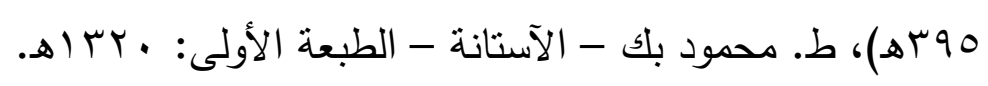

• ع.ظاهرة التتغيم في التراث العربي، د. هايل محمد الطالب، منشور في مجلة التراث العربي، تصدر عن اتحاد الكتاب العرب - دمشق - العدد (19) - السنة

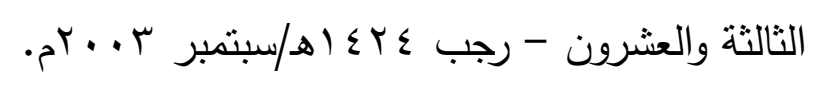

اع. ظاهرة الشعر المعاصر في المغرب: مقاربة بنيوية تكوينية، محمد بنيس، ط. دار

$$
\text { التنوير للنشر - بيروت - } 910 \text { ام. }
$$

ץع. علامات الترقيم في اللغة العربية، د. فخر الدين قباوة، ط. دار الملتقى للطباعة

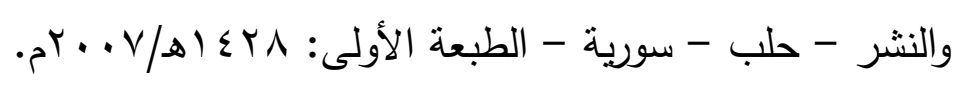

باء. علم الأصوات، د. كمال محمد بشر ، ط. دار غريب - القاهرة - الطبعة الأولى:

$$
\text { . }
$$


ـ ـ.علم التجويد القرآني في ضوء الدراسات الصوتية الحديثة، د. عبد العزيز

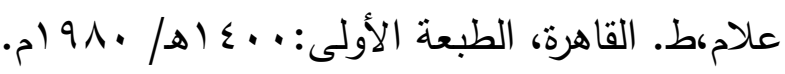

0ـ. علم اللسانيات الحديثة، د. عبد القادر عبد الجليل، ط. دار صفاء - عمان -

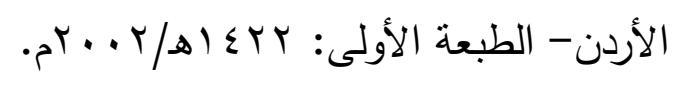

דـ.علم اللغة مقدمة للقارئ العربي، د.محمود السعران، ط.دار الفكر العربي -

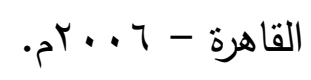

VI V الفاصلة القرآنية بين المبنى والمعنى، د. عيد محمد شبايك، ط. دار حراء -

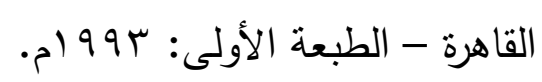

^ــ فن الإلقاء الرائع، د.طارق سويدان، ط. شركة الإبداع الفكري- الكويت- الطبعة

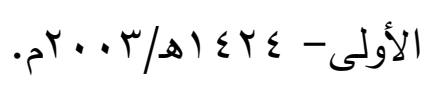

9. فن الإلقاء بين النظرية والنطبيق، د. نجاة علي، ط. الدار المصرية اللبنانية -

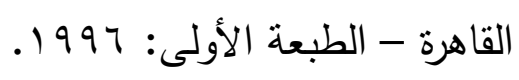

•. فن الإلقاء، د. عبد الحميد حسن، ط. دار نشر الثقافة - الإسكندرية (د.ط،

$$
\text { د.ت) }
$$

10.0ن الإلقاء، عبد الوارث عسر.ط. الهيئة المصرية العامة للكتاب - القاهرة -

$$
\text { - م) } 91 \mathrm{r}
$$

ror. فن الكلام، د. كمال محمد بشر، ط. دار غريب - القاهرة (د.ط) r. .ب م. rه. القراءة الجهرية بين الواقع وما نتطلع إليه، د. سليمان العايد، من بحوث ندوة (ظاهرة الضعف اللغوي في المرحلة الجامعية)، المنعقدة في كلية اللغة العربية،

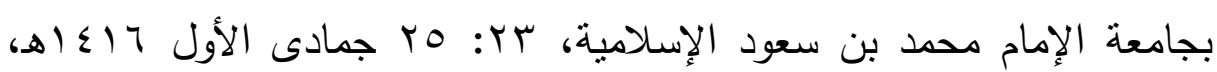


ــ. الكافي في العروض والقوافي، للخطيب التبريزي (أبي زكريا يحيى بن علي بن محمد بن الحسن الثيباني، ت ب.0هـ)، تح. الحساني حسن عبد الله، نشر :

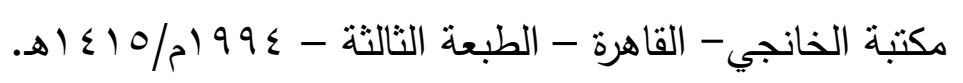
0. الكثّاف عن حقائق غوامض التنزيل وعيون الأقاويل في وجوه التأويل،

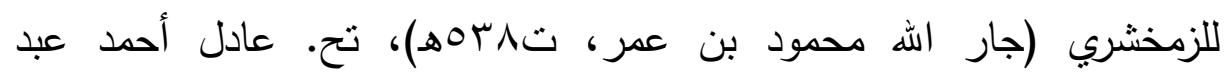
الموجود، وعلي محمد معوض، ط. مكتبة العبيكان - الرياض - الطبعة الأولى:

$$
\text { .م) } 991 / \Delta) \leq 11
$$

1.0لسان العرب، لابن منظور (محمد بن مكرم بن على بن أحمد الأنصاري، ت

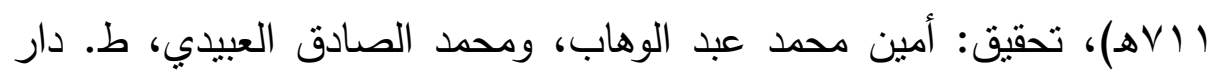
إحياء التراث العربي، ومؤسسة التاريخ العربي - بيروت - لبنان - الطبعة

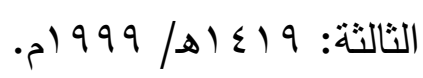

V. V. اللغة العربية معناها ومبناها، د. تمّام حسّان، ط. دار الثقافة - الدار البيضاء . $199 \leq$ (b.د)

^ه. المدخل إلى علم أصوات العربية، د. غانم قدوري الحمد، منشورات المجمع

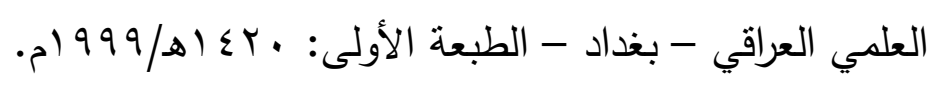

هـ المدخل إلى علم اللغة ومناهج البحث اللغوي، د. رمضان عبد التواب، ط. مكتبة الخانجي - القاهرة - الطبعة الثانية: 910 ام.

• 7. المعجم الوسيط، ط. مجمع اللغة العربية بالقاهرة، الطبعة الرابعة:

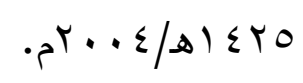


آT.معجم مقاييس اللغة، لابن فارس (أبي الحسين أحمد بن فارس بن زكريا، ت

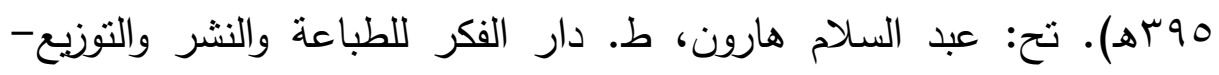

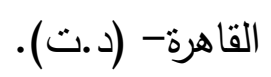

rT.مفتاح العلوم، للسكاكي(أبي يعقوب يوسف بن أبي بكر، ت جrآهـ)، تعليق:

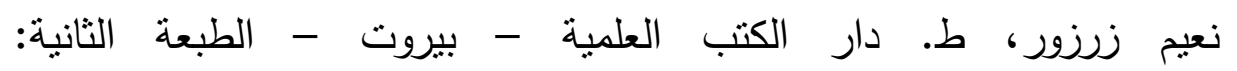

$$
.519 \Lambda \mathrm{V} / \mathrm{s}) \leq \cdot \mathrm{v}
$$

rآ. المفردات في غريب القرآن، للراغب الأصفهاني (أبي القاسم الحسين بن محمد ت

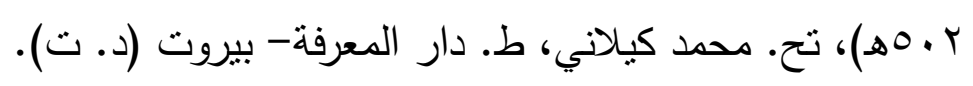

ـا. من قضايا اللغة، د. مصطفى النحاس، مطبوعات جامعة الكويت - الطبعة

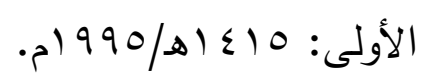

10. من وظائف الصوت اللغوي: محاولة لفهم صرفي ونحوي ودلالي، د. أحمد كثنك، ط. القاهرة - الطبعة الثانية: 199 1.

47. مناهج البحث في اللغة، د. تمام حسان، ط. دار الثقافة - الدار البيضاء -

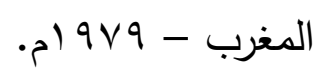

لآ. الموجّه الفني لمدرسي اللغة العربية، عبد العليم إبراهيم، ط. دار المعارف -

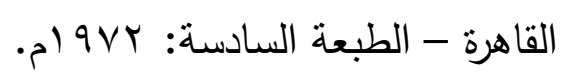

1ا7. موسوعة كثاف اصطلاحات الفنون والعلوم، لمحمد علي التهانوي، تح: د.علي دحروج عناية، و د. عبد الله الخالدي، ترجمة: د.جورج زيناتي، ط ـ ـ مكتبة لبنان

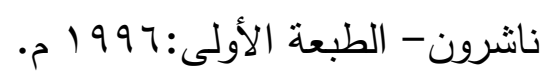

9 79.نحو تعليم اللغة العربية وظيفياً، داود عبده، ط. مؤسسة دار العلوم - الكويت -

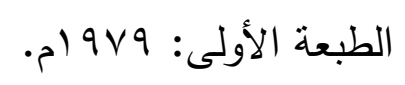


• •.النشر في القراءات العشر، لابن الجزري (أبي الخير محمد بن محمد ت

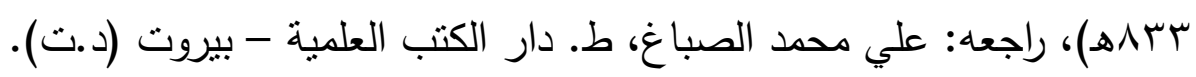

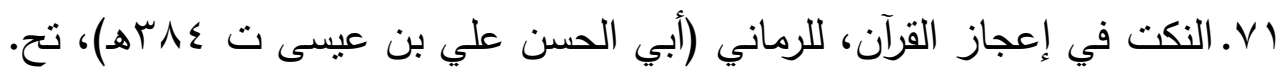
محمد خلف اله أحمد، ومحمد زغلول النجار (ضمن ثلاث التان رسائل في إعجاز

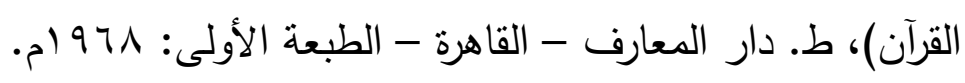

